\title{
Literatura i promoció social: lectura i creació literàries entre els menestrals catalans medievals
}

\author{
Lluís Cifuentes i Comamala
}

Universitat de Barcelona

lluiscifuentes@ub.edu

https://orcid.org/OOOO-OOOI-79I2-9859

Received: 08/o6/202I; accepted 27/07/202I

DOI: https://doi.org/IO.7203/MCLM.8.2IOI4

Literature and social promotion: literary reading and creation among medieval Catalan artisans

\section{ABstract}

This article aims to prove the active role played by artisans as consumers (readers, owners, copyists) and authors of literature besides elite and court circles, and links it to the strategies of social promotion launched by that dynamic social group. The analysis is based on two types of sources: on the one hand, on an extensive sample of the presence of literary works in the libraries of the medieval Catalan lower middle classes, derived from the main documentary collections on history of the books produced to date; and, on the other hand, on some literary codices copied by individuals belonging to that social sphere, which have been re-examined. In addition, some individuals are identified regarding the transmission of some works of Francesc Eiximenis (Llibre de les dones and Llibre dels àngels) and the Catalan translation of La Queste del saint Graal, as well as regarding the origin of Jaume Conesa's translation of Guido delle Colonne's Historia destructionis

\section{Troie.}

\section{KEYWORDS}

Catalan artisans; authors, readers and books; medieval book history; medieval literature; libraries; manuscripts; copyists; colophons; social promotion

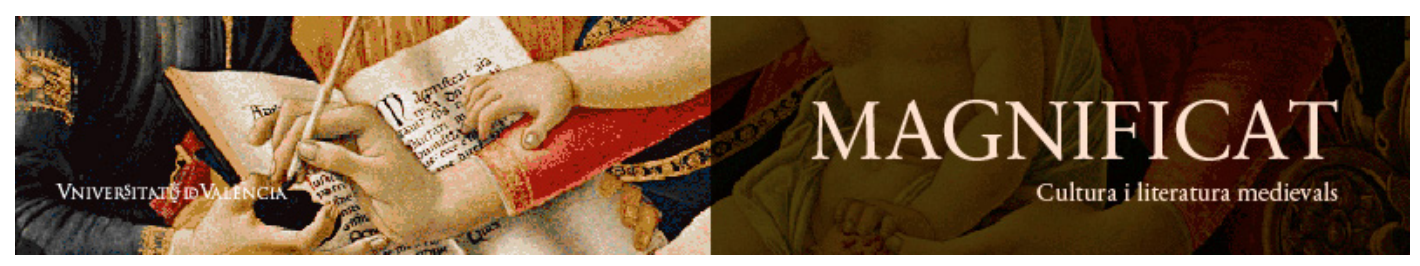

Magnificat Cultura i Literatura Medievals 8, 202I, 57-108. http://ojs.uv.es/index.php/MCLM

ISSN $2386-8295$ 
RESUM

Aquest article reivindica el paper actiu dels menestrals com a consumidors (lectors, posseïdors, copistes) i autors de literatura, al costat dels cercles de l'elit i de la cort, i el relaciona amb les estratègies de promoció social que aquest dinàmic sector va endegar. L'anàlisi es fonamenta en dos tipus de fonts: d'una banda, en una extensa mostra de la presència d'obres literàries en les biblioteques de la petita burgesia catalana medieval, a partir de les principals col-leccions documentals sobre història del llibre produïdes fins ara; i, d'altra banda, en alguns còdexs literaris copiats per individus pertanyents a aquest àmbit social, que han estat reexaminats. A més, s'hi identifiquen alguns personatges relacionats amb la transmissió d'algunes obres de Francesc Eiximenis (el Llibre de les dones i el Llibre dels àngels) i amb la de la traducció catalana de La Queste del saint Graal, i també amb l'origen de la traducció de Jaume Conesa de la Historia destructionis Troie de Guido delle Colonne.

PARAULES CLAU

Menestrals catalans; autors, lectors i libres; historia medieval del llibre; literatura medieval; biblioteques; manuscrits; copistes; colofons; promoció social

Lluís Cifuentes. 202I. 'Literatura i promoció social: lectura i creació literàries entre els menestrals catalans medievals', Magnificat Cultura i Literatura Medievals, 8: 57-Io8, DOI: https://doi. org/IO.7203/MCLM.8.2IOI4

Aquest article exposa resultats d'una recerca finançada pel projecte Narpan II: Vernacular Science in the Medieval and Early Modern Mediterranean West (MCIU-AEI/FEDER PGC 20I8-0954I7-B-C64) i pel grup consolidat Cultura i literatura a la Baixa Edat Mitjana (AGAUR 20I7 SGR I42).

\title{
TAULA DE CONTINGUTS
}

\author{
I Els menestrals, lectors de literatura -60 \\ 2 Menestrals 'copistes'? Els llibres autògrafs - $7^{1}$ \\ 2.I El Guillem Reixac de la Història del sant Graal - 73 \\ 2.2 Eiximenis, copiat de mà de menestrals - 74 \\ 2.3 Les Històries troianes del candeler Bartomeu Miquel - 76 \\ 2.4 El blanquer Bernat Nicolau i la Comèdia de Dante - 86
}

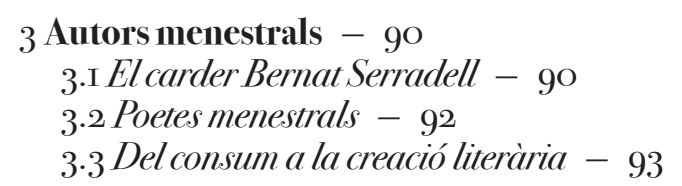

4 Literatura i promoció social - 94

5 Agraïments - 99

6 Abreviatures emprades - 99

${ }_{7}$ Obres citades - IOI 


\section{ə*⿻}

E Lls estudis d’història de la literatura catalana medieval han anat evidenciant aquí i allà, en notícies sobretot isolades, el protagonisme que van tenir els individus que exercien oficis tècnics entre els lectors i, en menor mesura, entre els autors d'obres de creació literària. L'aportació més sistemàtica és encara Cingolani 199O-9I, que proporciona un important repertori de referències sobre el públic lector de literatura extretes de la bibliografia publicada fins aquell moment. Tanmateix, malgrat la sensible presència de menestrals en aquest corpus, el focus analític es posa en l'elit social, en els nobles, 'ciutadans' i mercaders, i, més concretament, en el monarca i el seu entorn. En efecte, és habitual que aquesta presència estranya dels menestrals no sigui objecte de cap comentari particular o bé que s'entengui com un reflex, transmès per capil-laritat, dels interessos culturals de la cort, sense qüestionar-se aquesta hipòtesi ni atendre a una anàlisi més afinada del com, el quan i el per què. Aquests punts de vista tradicionals, que acaben generant prejudicis, semblen conseqüència de la relativa exigüitat de les fonts que llavors, i fins fa poc, es tenien a l'abast, però també depenen de la manera com han estat interpretades aquestes fonts.

Darrerament, s'és conscient que cal una anàlisi més contextualitzada dels testimonis coneguts. Aquesta anàlisi, sumada a la presa en consideració d'altres tipus de fonts, a un enfocament més interdisciplinari, al descobriment de nous testimonis i a un despullament sistemàtic de la nombrosa documentació sobre llibre i lectura que ha estat publicada, comença a oferir un panorama més equilibrat del tema i, per contraposició a la visió tradicional, ben sorprenent. En les pàgines que segueixen s'analitza una extensa mostra de la presència d'obres literàries medievals en les biblioteques de la menestralia, feta a partir del buidatge de les principals col-leccions documentals publicades fins ara, i, paral-lelament, s'estudien alguns còdexs literaris copiats per individus pertayents a aquest entorn social i els casos d'alguns autors que eren menestrals. A partir d'aquestes dades es fan unes propostes d'estudi de la relació dels menestrals amb la literatura durant els últims segles medievals.

El marc cronològic d'aquest treball és la baixa Edat Mitjana i l'inici de l'època moderna, en concret els segles XIV, XV i la primeria del XVI. Aquest marc cronològic és determinat per l'existència de fonts útils per a l'estudi del tema, però principalment pel descabdellament dels nous models socioculturals que el ple restabliment de la societat urbana havia originat, en els quals el llibre, la lectura i l'escriptura van esdevenir realitats quotidianes en sectors socials cada vegada més amplis. El marc geogràfic de referència és el dels Països Catalans -en aquell temps, el Principat de Catalunya i els regnes de Mallorca i de València- i s’emprarà el gentilici 'català' per als habitants d'aquest territori, com era usual a l'època.

El concepte 'menestral' s'empra aquí assumint l'anacronisme de fusionar-hi l'estament urbà dels 'menestrals', pròpiament dit (paraires, teixidors, blanquers, fusters, sabaters, sastres, pintors, etc.), i, en bona mesura, el dels 'artistes' (cirurgians, apotecaris, barbers, candelers, etc., però deixant-hi de banda els notaris, advocats, juristes o metges), amb l’objectiu de reunir el conjunt d'oficis de la petita burgesia, en un sentit ampli, que tenien en comú un sistema de formació obert, basat en l'aprenentatge, el treball manual i l'organització en confraries i gremis. A partir de mitjan segle XV, els 'artistes' es van separar dels 'menestrals' en moltes ciutats -però no pas en totes, com ara a Mallorca (Hillgarth I99I: 43, per als cirurgians) - i se'n van diferenciar per tendir a tenir una formació en estudis reglats, a exercir les 'arts liberals' o oficis no mecànics, i a organitzar-se en col-legis. A més, alguns oficis van canviar d'estament amb el temps. Per tota aquesta complexitat i 
perquè l'objectiu és centrar l'estudi en la petita burgesia en general, s'ha optat pel terme 'menestral'. L'estudi exclou els sectors superiors de la burgesia (el patriciat urbà, que a les fonts solia designar-se amb l'apel-latiu de 'ciutadans' o 'prohoms', els mercaders i les professions liberals esmentades més amunt). El contacte d'aquests sectors amb el món del llibre ha estat objecte d’altres aportacions.

\section{Els menestrals, lectors de literatura}

Als Països Catalans, la història del llibre i de la cultura escrita ha anat exhumant, des dels temps d’A. Rubió i Lluch, un autèntic devessall de dades sobre l'època medieval que en els darrers trenta anys s'ha fet enorme mercès a iniciatives personals com les de J. N. Hillgarth (I99I) o J. Hernando (I995 i 2000), sobre Mallorca i Barcelona, respectivament, i amb les tesis doctorals de M. L. Mandingorra (I989), M. R. Ferrer (I993), J. Iglesias (I996a) o M. Torras (2004), sobre València, Barcelona i Manresa; unes tesis que, malauradament, no sempre tenen l'accessibilitat que mereixen. La documentació conservada, especialment la notarial, és ingent, i conté molta més informació que la publicada fins ara. Fons documentals de la rellevància dels de Vic, Girona, Puigcerdà, Perpinyà o els de les comarques tarragonines o les de l'interior del País Valencià esperen un treball sistemàtic sobre el tema, si no la simple exploració, que l'esforç de catalogació que s'ha fet des dels anys I980 ara faciliten. Tal com ja va demanar Cingolani fa una colla d'anys al treball esmentat, la informatització interrelacionada i la divulgació a la xarxa de tot aquest material -no tan sols el publicat en les obres principals sinó també en el reguitzell de treballs breus que van catalogar Faulhaber I987, Martín Abad I989, I994 i I998 i Gudayol I998 i 2000 i els que han aparegut després- proporcionaria un recurs sobre el llibre, la lectura i la cultura escrita a l'Europa medieval d'un abast i d'un valor incomparables. ${ }^{\mathrm{I}}$

Com ja han fet notar els autors de les esmentades iniciatives i tesis doctorals, de la documentació publicada en les últimes dècades n’emergeix un panorama molt més ric, complex i entenedor que el que van poder conèixer J. Sanchis Sivera, R. Carreras Valls, J. M. Madurell, J. Rubió i Balaguer o G. Llompart, per esmentar només les figures més eminents que fins llavors havien estudiat la circulació del llibre i la lectura a l'àmbit cultural català. A més, la interpretació d'aquestes fonts s'ha beneficiat de les noves orientacions metodològiques, vingudes d'Itàlia, que han fet de la paleografia i la codicologia una autèntica història de la cultura escrita, posant l'accent en els aspectes sociològics i, ben concretament, en l'alfabetització (destaquen les aportacions de G. Cavallo, A. Petrucci i, al nostre context, F. M. Gimeno Blay).

No obstant això, més enllà dels cercles especialitzats, aquestes aportacions no han aconseguit desterrar del tot el vell tòpic d'un analfabetisme pràcticament generalitzat -llegiu: a les capes socials inferiors- i d'un interès nul o bé limitat o excepcional -i al tòpic, l'excepció sempre és explicable en termes d'un interès espuri: possibles herències o inversions- per la cultura librària, i els coneixements, possibilitats de lleure o gustos que aquesta cultura librària vehiculava, en els estrats més baixos de la societat a l'Occident medieval. Aquesta fotografia, que podia ser certa al ruralitzat continent de l'època altmedieval, amb la cultura i l'escriptura recloses als monestirs, a les catedrals i a algunes corts -ço és, en una elit lletrada formada quasi exclusivament per clergues que, amb els trobadors començarà a ampliar-se-, es difumina i s'esmicola a partir del segle XIII. La pacificació del continent permet la recuperació del comerç i l'aparició de la burgesia, i, amb

I. Un estat de la qüestió fins a la seva data de publicació a Iglesias I993 (i primer capítol d’Iglesias i996a: 5-37). Com recorda Iglesias (I993: 40; I996a: I, 6, 48), la creació d'un corpus de biblioteques privades medievals ja havia estat reclamada per R. d’Alòs-Moner i per J. Rubió i Balaguer (Madurell-Rubió I955: $99^{*}$ ). 
aquesta, la revitalització de les ciutats, en les quals reneix la cultura urbana, les preocupacions, necessitats i anhels d'una societat urbana, des dels més materials -la correcta gestió del govern i de les relacions humanes, de l'alimentació i de la salut- fins als més intangibles -la promoció social, el desig d'entreteniment, la creació artística i literària-, i tot amb el rerefons d'una nova religiositat més amable, factible, urbana, que legitima i controla alhora. En aquest nou context, l'escriptura i el saber, la lectura i els llibres, adquiriran una importància desconeguda fins aleshores, en comprovarse que eren útils no tan sols com a eines de comunicació, de gestió, d'aprenentatge, d'entreteniment o de creació, sinó també com a instruments que possibilitaven la promoció de l’individu.

L'estrat inferior de la burgesia, format per la gent que exercia els oficis menestrals, va tenir un contacte més estret i fecund del que sol pensar-se amb l'escriptura i els llibres. En un món tan diferent del d'aquella societat altmedieval, en el qual les relacions humanes pivotaven més i més sobre l'escriptura, no és estrany que es llancessin a garantir-se'n el domini. Als seus inventaris de béns, els estris i, sobretot, les obres didàctiques que els el possibilitaven tenen una presència molt important, ${ }^{2}$ com la hi té també el principal objectiu d'aquest domini de l'escriptura: els registres comptables amb els quals gestionaven els seus negocis i que les necessitats quotidianes, primer, i les lleis, després, feien imprescindibles. ${ }^{3}$

Més enllà d'aquest objectiu pragmàtic, l'escriptura demostrava ser un instrument útil per a la fixació, la transmissió i l'adquisició del saber tècnic. Van aparèixer així els manuals tècnics que servien de guia per a la pràctica quotidiana de l'ofici i per a la formació dels novells artesans. Els artesans que exercien els seus oficis en un dels àmbits més valorats en una societat urbana com és el de la salut, molt particularment els metges pràctics -cirurgians, barbers, metgesses-, que es formaven segons el mateix sistema obert d'aprenentatge de tots els menestrals i que eren el paraigua sanitari de la majoria de la població, van prendre la iniciativa i, al segle XIII, els més cultes d'entre ells van elaborar manuals en llatí -la llengua que tradicionalment havia estat la de l'escriptura i el

2. Hi apareixen les obres habituals que donaven una formació bàsica en la lectura i l'escriptura a partir de la gramàtica llatina (les Partes de Donat, el Grecismus d'Évrard de Béthune, el Doctrinale puerorum d'Alexandre de Villedieu, etc.), a les quals s'afegien textos de doctrina moral (els Disticha del ps.-Cató o l'anònim Contemptus mundi) o religiosos (el Tobias de Mathieu de Vendôme, oracions i, en particular, el Salitiri, sobre l'ús didàctic del qual, en llatí i en català, vegeu Rubió I97I: 3I*; Llompart I975-77: 22I-22; o Hillgarth I99I: doc. 306.I-2). A aquest corpus s'hi sumava alguna obra narrativa llatina, com ara l’Alexandreis de Gautier de Châtillon, una reconstrucció en vers de la vida d'Alexandre el Gran que va tenir una gran influència (Hernando I995: 23; Hillgarth r99I: I80). Aquesta formació, que era i podia ser més complexa segons la vida a la qual s'encaminava el jove i la seva extracció social, podia adquirir-se en escoles de diversa mena o a l'àmbit domèstic, contractant mestres particulars que podien fer també altres tasques de servei (Rubió I97I: $26^{*}-32^{*}$ ). La documentació conservada informa que els menestrals tenien al seu abast tant el circuit escolar elemental (Llompart I975-I977: 205; treballs d'Hernando citats a continuació o el que es dirà a propòstit d'un ms. de les Històries troianes autògraf d'un candeler) com la contractació de mestres (és interessant Hernando I995: doc. 426 , despeses en un mestre i llibres per al fill d'un corder, I396; aquest i altres casos a Hernando I993-97 i 2005). La didàctica amb textos en vulgar devia penetrar sobretot en l'àmbit domèstic (Rubió I97I: $27^{*}-28^{*}$ ), per al qual està pensada la pauta exposada per Ramon Llull (Doctrina pueril, pròleg; Blaquerna, cap. 6), mentre que Francesc Eiximenis (Renedo 1993; Guixeras-Renedo 2005) ofereix una justificació ideològica per a l’alfabetització i la formació dels estrats urbans, i no és estrany que un i altre autors fossin llegits pels menestrals, en particular el segon. Al costat de les traduccions catalanes del Saltiri o del ps.-Cató, les obres en vulgar de Llull o el Llibre dels àngels d'Eiximenis exercien suplementàriament el paper d'instruments didàctics per a l'aprenentatge del català escrit (Llompart $1975^{-}$ 77: 222; Hillgarth I991: 247; i aquí, més endavant). Les propostes de Llull i d'Eiximenis, en lloc de veure-les com a genialitats o innovacions, s'haurien d'entendre com un testimoni escrit o una teorització i una legitimació del que ja era un fet, amb una demanda social viva, en el context en el qual van elaborar les seves obres.

3. S'han estudiat els llibres de comptes d'un argenter (Fuente I997), d'un paraire (Cáceres 2003) i d’un apotecari (edició a Vela 2003). El darrer és l'únic que examina les mans que hi intervenen. Per als llibres de gestió dels apotecaris, vegeu Cifuentes 2016 i la bibliografia que cita. 
saber-que de seguida van traduir-se o fer-se traduir a les llengües vulgars. No van ser els únics a procurar-se guies escrites de l'ofici.

En una segona fase, ja al segle XIV, menestrals d'altres oficis van procurar-se guies tècniques que feien una funció similar. En aquests altres oficis, el fet devia ser prou estès i habitual perquè als inventaris dels béns que deixaven en morir apareixen en una quantitat molt significativa, tot i que limitada perquè els notaris que elaboraven aquests documents tendien a no identificar les obres que no tenien importància econòmica -i aquestes, extremament utilitàries com eren, no en tenien gens-i només les designaven de manera genèrica i, sovint, per lots. ${ }^{4}$ Sabaters, argenters, pintors, il-luminadors, corretgers, tintorers, etc. tenien manuals i mostraris, però si l'ofici no era continuat pels descendents o aprenents, o no es donaven circumstàncies excepcionals -com ara la deixa dels béns a la beneficència-, solien acabar destruïts, igual com els llibres de comptes; un destí que tard o d'hora, en la immensa majoria dels casos, ja era determinat per la poca consistència d'aquests volums. El manual de tintoreria de Joanot Valero (Cifuentes-Córdoba 2OII) és un supervivent excepcional d'aquestes obres, elaborat el I 497 per aquest tintorer aragonès establert a València a partir d'un manual anònim anterior que li hauria transmès el seu mestre. És, també, un exemple d'aquests altres usos de l'escriptura i el llibre als ambients menestrals més enllà del pragmatisme dels registres comptables, i demostra -malgrat un altre tòpic molt estès a causa de l'exigüitat de les fonts conservades- que, en la formació dels artesans, l'oralitat aviat va haver de fer un lloc a la transmissió escrita. ${ }^{5}$

En aquest nou context urbà tan dinàmic, la tècnica, el treball fet amb les mans, havia guanyat el prestigi social que no tenia en els segles altmedievals: treballar i exercir algun ofici ja no era un càstig diví; l'ociositat, amb excepcions, no tenia la mateixa respectabilitat social; exercir l'ofici amb els coneixements i mètodes adequats era garantia d'èxit econòmic i social -altrament dit, saber més significava ser més, en una concepció instrumentalista del saber. Són punts de vista que impulsava tota la burgesia en bloc, per fer front a la pressió nobiliària. Punts de vista que eren la palanca del gran objectiu d'aquests sectors, que no era altre que la promoció social, i que eren darrere de l'auge dels oficis, de l'associacionisme dels menestrals, de la seva exigència de participació política en el govern de les ciutats, que monopolitzava l'oligarquia burgesa, i també del seu interès per la cultura escrita, pel llibre i per la lectura.

Les expressions de sorpresa que, tant des de la història de la literatura com des de la història del llibre, encara hi havia temps enrere sobre la possessió de llibres -en particular llibres amb obres de literatura- per part dels menestrals, ${ }^{6}$ han emmudit davant l'evidència que suposa la profusió de notícies que se n’han anat coneixent. El tema de la possessió de llibres en general per part dels menestrals va ser destacat especialment per Iglesias ig96b, que va comentar un important repertori d'inventaris barcelonins del segle XV, i sol tenir un lloc als estudis d'història del llibre abans esmentats. ${ }^{7}$ No se n'ha fet, però, cap estudi sistemàtic, tampoc de la presència d'obres literàries a les

4. Expressions com ara "romanços e cartapaços de pocha valor entrò a .L.” (Francesc Satorre, apotecari de Manresa, I386, a Torras 2004: doc. I72, núm. 4, i a Sciència.cat DB doc9o) o bé "huyt libres de paper sotils, entre grans, migancers e chiques, tots desqüernats e de pocha valor” (Nicolau Martí, barber-cirurgià de València, I 432, a Ferrer I993: doc. 24, s. núm., i a Sciència.cat DB doc24I) són freqüents als inventaris. Quan es conserva l'inventari i també el registre de la venda dels béns a l'encant públic, no és estrany que aquests llibres secundaris no hi apareguin (com els mostraris d'un corretger o d'un coquer de Barcelona de I438 i I 450 , a Iglesias I996a: doc. I9I-92, 25I-52).

5. A l'edició esmentada (Cifuentes-Córdoba 2OII: 65-66) es recullen algunes referències a aquests manuals en inventaris de béns sobretot a partir d'Iglesias i996a i d'altres fonts, que es poden ampliar a la base de dades Sciència. cat DB, s.v. "manual” i “mostrari”. Vegeu també Ferrer I993: I83-84. El manual de Valero inclou un petit apartat de comptes i un receptari mèdic per fer front a les seves necessitats personals -de l'ofici- i familiars.

6. Vegeu, per exemple, el diagnòstic negatiu de Llompart I975-77: 203-o6.

7. Ferrer I993: I80-9I; Iglesias I996a: I97-206; Torras 2004: 337-48, barrejant-hi els mercaders. En altres estudis, 
seves biblioteques; un estudi sistemàtic que només seria possible amb la informatització del material disponible abans al.ludida.

La taula adjunta, elaborada a partir d'un buidatge de les principals publicacions a l'abast sobre Barcelona, València, Mallorca, Perpinyà, Girona, Vic i Manresa, és només una mostra de les possibilitats del tema. S'hi pot observar que el panorama és molt més sorprenent del que se suposa en els estudis esmentats, tots ells centrats en una ciutat o regió determinades. D’acord amb el que s'ha avançat en la introducció, la taula recull les obres literàries, en qualsevol llengua, posseïdes per individus que exercien oficis tècnics i que es formaven pel sistema obert d'aprenentatge: s'hi inclouen, per tant, sabaters, sastres, paraires, cirurgians, barbers, apotecaris, candelers, etc. i també els practicants d'alguns altres oficis dels graons inferiors del comerç (drapers, mercers) i l'administració (algutzirs, corredors) o vinculats, segurament a un nivell acabalat, a activitats primàries (mariners, pescadors, pagesos). No es contemplen, però, tot i pertànyer al mateix context urbà, els membres de l'elit burgesa ('ciutadans', mercaders), els individus que exercien professions liberals, en les quals pesava la formació escolar o intel-lectual (juristes, advocats, notaris o escrivans, físics), ni tampoc els llibreters, per la projecció comercial que tenien. Per tant, com també s’ha dit, el ventall social que reprodueix la taula no es correspon amb les classificacions estamentals de l'època, que, d'altra banda, no van ser ni generals ni immutables. Tanmateix, alguns estudis (com ara Iglesias 1996a) prenen l'opció contrària, pel fet de centrar-se en una ciutat determinada i ajustarse a la seva normativa social concreta. Al capdavall, cal dir que si s'adaptés la taula a aquesta altra opció, pràcticament no variaria més que en extensió.

Al'hora de decidir quins textos es tenien en compte, s'ha optat per un ventall molt similar al considerat per Cingolani 1990-9I: obres de creació i entreteniment medievals -excloses, per tant, les traduccions de clàssics-, tant en vers com en prosa, en les quals aquestes formes estiguin al servei d'aquells objectius o que també poguessin ser llegides en aquell sentit. ${ }^{8}$ Això inclou alguns textos religiosos en els quals prima la construcció d’un relat (si bé es prescindeix de les vides de sants, de Jesucrist i de la Mare de Déu, i de les històries de la Passió, molt freqüents en aquestes biblioteques) i també, pel mateix motiu, les obres historiogràfiques (vegeu fig. I). En canvi, s'exclouen, per les mateixes raons, les obres doctrinals o enciclopèdiques de Ramon Llull i Francesc Eiximenis, amb una forta presència en les llibreries dels menestrals, en particular les del darrer, i també el Breviari d'amor i la Consolació de Boeci, que hi tenen una incidència menor per comparació amb les biblioteques de l'elit. Finalment, a l'apartat "Lírica” cal tenir present que, en molts casos, les referències documentals són tan ambigües que no es pot precisar de quines obres en vers es tractava i molt probablement se n'hi amaguen que ja apareixen als altres apartats o que no haurien de ser a la taula, i això és així bé pel poc coneixement que els notaris en tenien, bé pel poc interès que posaven a descriure-les, sabent que no se’n podia obtenir cap preu. Per això mateix, la prudència ha fet prescindir també dels llibres "de cant" que apareixen en alguns inventaris. 


\begin{tabular}{|c|c|c|c|}
\hline \multicolumn{4}{|c|}{ LA LITERATURA A LES BIBLIOTEQUES DELS MENESTRALS CATALANS (SEGLES XIV-XVI) } \\
\hline Obra & Menestral & $\begin{array}{l}\text { Lloci } \\
\text { data }\end{array}$ & Font \\
\hline \multicolumn{4}{|c|}{ LíRICA } \\
\hline 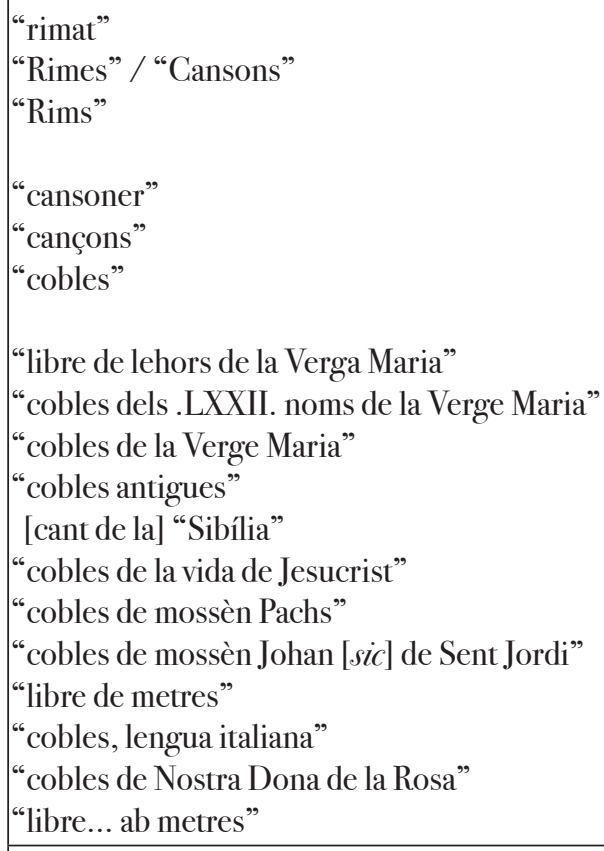 & $\begin{array}{l}\text { Francesc Moliner, cirurgià } \\
\text { Francesc Ferrer, apotecari } \\
\text { Bernat Gibert, sastre } \\
\text { Bernat Isern, pesador } \\
\text { Guillem Garriga, balancer } \\
\text { Pere Berriac, apotecari } \\
\text { Francesc Anglada, paraire } \\
\text { Jaume Cebrià, cirurgià } \\
\text { Romeu Desfeu, argenter } \\
\text { Honorat Miquel, apotecari } \\
\text { Guillem Font, paraire } \\
\text { Bernat Planell, apotecari } \\
\text { Guillem Sans, pintor } \\
\text { Jaume Cebrià, cirurgià } \\
\text { Jaume Cebrià, cirurgià } \\
\text { Jaume Cebrià, cirurgià } \\
\text { En Valls, peller } \\
\text { Vicenç Domènec, paraire } \\
\text { Joan Soler, barber } \\
\text { Baptista Rotllan, apotecari } \\
\end{array}$ & 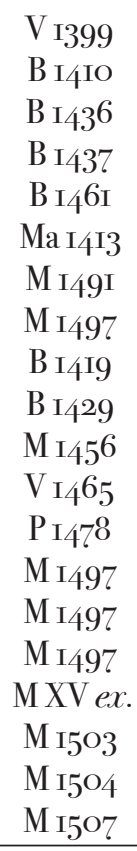 & 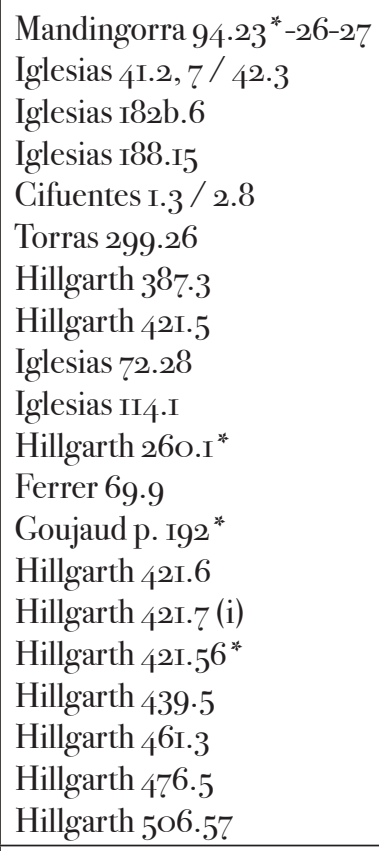 \\
\hline Mossé Natan, poemes & $\begin{array}{l}\text { Pere Descastell, daurador } \\
\text { Guillem Garriga, balancer }\end{array}$ & $\begin{array}{l}\text { Vi I } 437 \\
\text { B I46I }\end{array}$ & $\begin{array}{l}\text { Junyent } 322^{*} \\
\text { Cifuentes } 2.6\end{array}$ \\
\hline \multicolumn{4}{|c|}{ HiSTÒRIES } \\
\hline $\begin{array}{l}\text { Bernat Desclot, Crònica } \\
\text { "Conquestes del rey d'Aragó" }\end{array}$ & $\begin{array}{l}\text { Francesc Ferrer, apotecari } \\
\text { Anònim, barber }\end{array}$ & $\begin{array}{l}\mathrm{B} \text { I4IO } \\
\mathrm{PXV} \text { m. }\end{array}$ & $\begin{array}{l}\text { Iglesias } 4 \mathrm{I} \cdot 3^{*} \\
\text { Sciència.cat DB doc78* }\end{array}$ \\
\hline $\begin{array}{l}\text { "Conquestes dels reys" [= Ramon Muntaner, } \\
\text { Crònica?] } \\
\text { "libre... de conquestes" }\end{array}$ & $\begin{array}{l}\text { Bernat Guillamet, vidrier } \\
\text { Pere Berriac, apotecari }\end{array}$ & $\begin{array}{l}\text { В I } 457 \\
\text { Мa I4I3 }\end{array}$ & \begin{tabular}{|l} 
Iglesias 268.I \\
Torras 299.2I / 300.6 \\
\end{tabular} \\
\hline $\begin{array}{l}\text { Conquestes d'Espanya [= Rodrigo Jiménez } \\
\text { de Rada, De rebus Hispanie] } \\
\text { "Canòniques d'Espanya” }\end{array}$ & $\begin{array}{l}\text { Salvador Caselles, paraire } \\
\text { Caterina, v. Guillem Coll, } \\
\text { algutzir }\end{array}$ & $\begin{array}{l}\mathrm{M}_{\mathrm{I} 45^{2}} \\
\mathrm{M}_{\mathrm{I} 44^{8}}\end{array}$ & $\begin{array}{l}\text { Hillgarth } 246 . \mathrm{I}^{*} \\
\text { Iglesias } 244.6\end{array}$ \\
\hline \multicolumn{4}{|c|}{ HistÒRIES BÍBLIQQUeS } \\
\hline Gamaliel & $\begin{array}{l}\text { Bernat Isern, pesador } \\
\text { Jofre de Colunya, corretger } \\
\text { Rafael Isern, pintor } \\
\text { Bartomeu Serra, argenter } \\
\text { En Pinyana, pellisser }\end{array}$ & $\begin{array}{l}\text { В I } 437 \\
\text { В I } 438 \\
\text { В I } 444 \\
\text { В I448 } \\
\text { В I } 448\end{array}$ & $\begin{array}{l}\text { Iglesias I88.6* } \\
\text { Iglesias I92.4 } \\
\text { Iglesias 23O.2* } \\
\text { Iglesias 24I. } 6^{*} / 242.9 \\
\text { Iglesias 242.9 }\end{array}$ \\
\hline
\end{tabular}




\begin{tabular}{|c|c|c|c|}
\hline Gamaliel (cont.) & $\begin{array}{l}\text { Galceran d'Anguera, } \\
\text { assaonador } \\
\text { Úrsula, v. Pere Torrent, } \\
\text { forner } \\
\text { Joan Llorenç, vidrier } \\
\text { Jaume Piquer, candeler } \\
\text { Pere Manyes, sastre } \\
\text { Gabriel Jacme, pagès } \\
\text { Bernat Ferrando, gerrer }\end{array}$ & $\begin{array}{l}\mathrm{V}_{\mathrm{I} 450} \\
\mathrm{~B}_{\mathrm{I} 45^{\mathrm{I}}} \\
\mathrm{B}_{\mathrm{I} 45^{\mathrm{I}}} \\
\mathrm{B}_{\mathrm{I} 460} \\
\mathrm{M}_{\mathrm{I} 5 \mathrm{O} 8} \\
\mathrm{M}_{\mathrm{I} 5 \mathrm{I} 3} \\
\mathrm{M}_{\mathrm{I} 5 \mathrm{I}}\end{array}$ & $\begin{array}{l}\text { Ferrer } 47 \cdot 2 \\
\text { Iglesias } 256.2^{*} \\
\text { Iglesias } 257^{*} \\
\text { Iglesias } 282.3 \\
\text { Hillgarth } 5{ }^{\mathrm{II}} \cdot 5,6 \\
\text { Hillgarth } 55^{\mathrm{I}} \\
\text { Hillgarth } 594 \cdot 4 \text { (i) }\end{array}$ \\
\hline $\begin{array}{l}\text { Barlaam i Josafat } \\
\text { “Abraam” }\end{array}$ & $\begin{array}{l}\text { Felipa, v. F. Simó, mercer } \\
\text { Bernat Babiloni, paraire } \\
\text { Jaume Cebrià, cirurgià }\end{array}$ & $\begin{array}{l}\mathrm{B}_{\mathrm{I}} 373 \\
\mathrm{M}_{\mathrm{I} 5} \mathrm{I2} \\
\mathrm{M}_{\mathrm{I}} 497\end{array}$ & $\begin{array}{l}\text { Hernando } 3 \mathrm{I} 4 \cdot 3 \\
\text { Hillgarth } 53^{8 .} 3^{*} \\
\text { Hillgarth } 42 \mathrm{I} . \mathrm{I} 2\end{array}$ \\
\hline \multicolumn{4}{|c|}{ MATÈRIA DE BRETANYA } \\
\hline Història del sant Graal & $\begin{array}{l}\text { Bernat Calaf, peller } \\
\text { Alemany d'Espanya, } \\
\text { apotecari } \\
\text { Guillem Font, paraire } \\
\text { Jaume Rovirola, apotecari }\end{array}$ & $\begin{array}{l}\text { В г399 } \\
\mathrm{M}_{\text {I } 4 \mathrm{I} 5} \\
\mathrm{M}_{4} 456 \\
\mathrm{Vi}{ }_{4} 469\end{array}$ & $\begin{array}{l}\text { Hernando } 442 . \mathrm{I}^{*} \\
\text { Hillgarth } \mathrm{I} 75 \text { (a) } \\
\text { Hillgarth } 260.2^{*} \\
\text { Junyent } 23^{*}\end{array}$ \\
\hline $\begin{array}{l}\text { Llibre de Merlí } \\
\text { Lo sompnide Merlí }\end{array}$ & $\begin{array}{l}\text { Guillem Andreu, paraire } \\
\text { Miquel Gombau, perpunter } \\
\text { Perpinyà Agustí, fuster } \\
\text { Violant, v. Vicent } \\
\quad \text { Argilagues, flequer }\end{array}$ & $\begin{array}{l}\mathrm{P}_{\text {I383 }} \\
\mathrm{B}_{\text {I39I }} \\
\mathrm{P}_{\text {I4II }} \\
\mathrm{V}_{\mathrm{I} 464}\end{array}$ & $\begin{array}{l}\text { Goujaud p. } 198 \\
\text { Hernando } 400 \\
\text { Goujaud p. } 194 \\
\text { Ferrer } 68.14\end{array}$ \\
\hline $\begin{array}{l}\text { Llibre de la destrucció de la Taula rodona } \\
\text { [=La mort le roi Artu?] } \\
\text { "libre del rey Artús" } \\
\text { [Lluís] "Gras" [= Tragèdia de Lançalot] }\end{array}$ & $\begin{array}{l}\text { Joan d'Alemanya, tintorer } \\
\text { Bartomeu Claret, apotecari } \\
\text { Pere Estaràs, paraire } \\
\text { Miquel Aguiló, corredor } \\
\text { d'orella }\end{array}$ & $\begin{array}{l}\mathrm{M}_{\text {I } 456} \\
\mathrm{M}_{\text {I } 463} \\
\mathrm{M}_{\text {I } 439} \\
\mathrm{~B}_{\text {I } 484}\end{array}$ & $\begin{array}{l}\text { Hillgarth } 25^{8.4} \\
\text { Hillgarth } 283 \cdot 57 \\
\text { Hillgarth } 2 \mathrm{I} 3 \\
\text { Crèdit } 47 \mathrm{I} .5 \text { (i) }\end{array}$ \\
\hline Lançalot del Llac & $\begin{array}{l}\text { Caterina, v. Guillem Coll, } \\
\text { algutzir }\end{array}$ & M I448 & Iglesias 244.I \\
\hline $\begin{array}{l}\text { Tristany de Lleonís } \\
\text { "en lenguo castellana" }\end{array}$ & $\begin{array}{l}\text { Antoni Comella, pintor } \\
\text { Bartomeu Asbert, mariner } \\
\text { Romeu Desfeu, argenter } \\
\text { Bernat Gibert, sastre } \\
\text { Bernat Isern, pesador } \\
\text { Rafael Isern, pintor } \\
\text { Maria, v. Jordi Cortell, } \\
\quad \text { forner }\end{array}$ & $\begin{array}{l}\text { Vi I396 } \\
\text { M I4I3 } \\
\text { В I4I9 } \\
\text { В I436 } \\
\text { В I437 } \\
\text { В I444 } \\
\text { M I5I5 }\end{array}$ & $\begin{array}{l}\text { Junyent } 3 \mathrm{I} 7 \\
\text { Hillgarth I66 } \\
\text { Iglesias } 72 . \mathrm{I} \\
\text { Iglesias I82b.8 } \\
\text { Iglesias I88.9 } \\
\text { Iglesias } 230.5^{*} \\
\text { Hillgarth } 567.5 \text { (i) }\end{array}$ \\
\hline \multicolumn{4}{|c|}{ GESTES EN PROSA } \\
\hline “Antioxia" & $\begin{array}{l}\text { Guillemona, v. G. Serra, } \\
\text { sastre }\end{array}$ & M I437 & Hillgarth 2o6..* \\
\hline Llibre de Godofré de Billó & $\begin{array}{l}\text { Guillemona, v. G. Serra, } \\
\text { sastre } \\
\text { Vicenta, v. Berenguer Prats, } \\
\text { teixidor }\end{array}$ & $\begin{array}{l}M_{\text {I } 437} \\
\text { V I } 445 \\
\end{array}$ & $\begin{array}{l}\text { Hillgarth } 206.5 \\
\text { Ferrer } 3^{8.8} \\
\end{array}$ \\
\hline "Amich" [i Melis?] & En Valls, peller & M XV ex. & Hillgarth 439.2 \\
\hline
\end{tabular}




\begin{tabular}{|c|c|c|c|}
\hline \multicolumn{4}{|c|}{ Novel-LES } \\
\hline "romanços" & \begin{tabular}{|l} 
Jaume de Benages, draper \\
Guillem de Caldes, \\
$\quad$ pescador \\
Antoni Jordà, paraire \\
Guillem Ponç, barber \\
Bernat de Salesnoves, \\
apotecari \\
Francesc Satorre, apotecari \\
Bernat de Montflorit, pintor \\
Pere Riba, sabater \\
Berenguer Canet, draper \\
Pere Berriac, apotecari \\
Pere Bossegós, barber \\
Joan Aguiló, apotecari \\
Guillem Brinquet, estanyer \\
\end{tabular} & 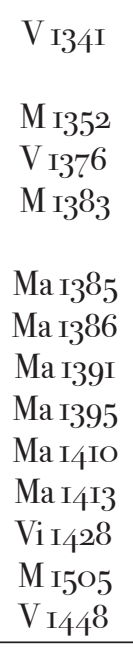 & $\begin{array}{l}\text { Mandingorra IO.2 } \\
\text { Hillgarth 47.I-3 } \\
\text { Mandingorra 48.I } \\
\text { Hillgarth II3.4 } \\
\text { Torras I68.3 } \\
\text { Torras I72.4 } \\
\text { Torras 220.3 } \\
\text { Torras 240.8 } \\
\text { Torras 290.I, 4, } 6 \\
\text { Torras 299.16, I8, 23, } 25 \\
\text { Junyent 46 } \\
\text { Hillgarth 485.IO } \\
\text { Ferrer p. I82 } \\
\end{array}$ \\
\hline $\begin{array}{l}\text { Vida d'Alexandre } \\
\text { "Alexandre" [=Gautier de Châtillon, } \\
\text { Alexandreis?] }\end{array}$ & $\begin{array}{l}\text { Joan Romanyà, paraire } \\
\\
\text { Ramon Palau, draper } \\
\text { Francesc Satorre, apotecari } \\
\text { Pere de Montserrat, sastre } \\
\text { mestre Bernat, sastre } \\
\text { Nicolau Exolin, pedrer } \\
\text { Marieta, v. Bartomeu Sanxis, } \\
\text { brodador } \\
\text { Guillem Garriga, balancer } \\
\text { Joan Palomar, teixidor } \\
\text { (oficial) } \\
\text { Bartomeu Claret, apotecari } \\
\text { Baptista Rotllan, apotecari } \\
\end{array}$ & 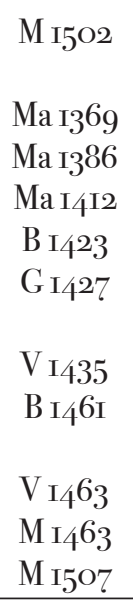 & $\begin{array}{l}\text { Hillgarth } 452 . \mathrm{I} \text { (i) } \\
\text { Torras } 125 \cdot 2 \\
\text { Torras I72.I3 } \\
\text { Torras } 298.3 \\
\text { Iglesias 90.I3 } \\
\text { Batlle p. } 440 \\
\text { Ferrer I3.7-9-I2-I3-I5 } \\
\text { Cifuentes } 2.6 \\
\text { Ferrer } 67.3 \\
\text { Hillgarth } 283.56 \\
\text { Hillgarth } 506.63\end{array}$ \\
\hline Ramon Llull, Blaquerna & $\begin{array}{l}\text { Romeu Desfeu, argenter } \\
\text { Baptista Rotllan, apotecari } \\
\end{array}$ & $\begin{array}{l}\text { B I419 } \\
\text { M } 1507\end{array}$ & $\begin{array}{l}\text { Iglesias } 7^{2.27} \\
\text { Hillgarth } 506.36\end{array}$ \\
\hline Ramon Llull, Llibre de meravelles & Jaume Rovirola, apotecari & Vi I469 & Junyent 69 \\
\hline Guido delle Colonne, Històries troianes & $\begin{array}{l}\text { Guillem Queralt, moneder } \\
\text { Joan Palomar, teixidor } \\
\quad \text { (oficial) } \\
\text { Guillem Garriga, balancer } \\
\text { Guillemona, v. G. Serra, } \\
\quad \text { sastre } \\
\end{array}$ & $\begin{array}{l}\mathrm{B}_{4} 44 \mathrm{O} \\
\mathrm{V}_{\mathrm{I} 460} \\
\mathrm{~B}_{\mathrm{I} 46 \mathrm{I}} \\
\mathrm{M}_{4} 437\end{array}$ & $\begin{array}{l}\text { Madurell I28* } \\
\text { Ferrer p. I87 i } 67 . \mathrm{I}\left(\mathrm{I}_{4} 63\right) \\
\text { Cifuentes } 2.6 \\
\text { Hillgarth } 206.3^{*}\end{array}$ \\
\hline Paris i Viana & $\begin{array}{l}\text { Julià Forns, paraire } \\
\text { Angelina, v. Mateu Maldà, } \\
\quad \text { sastre } \\
\text { Joan Nicolau, mariner }\end{array}$ & $\begin{array}{l}\mathrm{M}_{1447} \\
\mathrm{~B}_{146 \mathrm{O}} \\
\mathrm{M}_{1518}\end{array}$ & $\begin{array}{l}\text { Hillgarth } 228 \\
\text { Iglesias 284.IO } \\
\text { Hillgarth 6IO.2 }\end{array}$ \\
\hline $\begin{array}{l}\text { Enric de Villena, Els dotze treballs } \\
\text { d'Hèrcules }\end{array}$ & Miquel Castell, coraller & $\mathrm{B}_{\text {I } 45} 6$ & Crèdit I5I.I \\
\hline $\begin{array}{l}\text { Història de la destrucció de Jerusalem } \\
\text { “Conquesta de Jherusalem” }\end{array}$ & $\begin{array}{l}\text { Oliver Borrossà, pellisser } \\
\text { Antoni Olivar, sabater } \\
\text { Bartomeu Senós, apotecari } \\
\end{array}$ & $\begin{array}{l}\mathrm{B}_{\text {I } 424} \\
\mathrm{~S}_{\text {I } 486} \\
\mathrm{~B}_{\text {I } 433} \\
\end{array}$ & $\begin{array}{l}\text { Iglesias } 98 / 99 \\
\text { Hillgarth } 372 . \mathrm{I} \\
\text { Iglesias ı67.8 } \\
\end{array}$ \\
\hline Romanç del marquès i dels set savis de Roma & $\begin{array}{l}\text { Jaume Sentguir, mariner } \\
\text { Antoni Olivar, sabater }\end{array}$ & $\begin{array}{l}\text { В }_{\text {I389 }} \\
\text { S }_{\text {I } 486}\end{array}$ & $\begin{array}{l}\text { Hernando } 383.2 \\
\text { Hillgarth } 37^{2} \cdot 3 \text { (i) }\end{array}$ \\
\hline Romanç de Josep & Pau Santanyà, fuster & $\mathrm{M}_{15} \mathrm{I} 4$ & Hillgarth $5^{64.2}$ \\
\hline
\end{tabular}




\begin{tabular}{|c|c|c|c|}
\hline Diego de San Pedro, Càrcer d'amor & $\begin{array}{l}\text { Maria, v. Jordi Cortell, } \\
\text { forner }\end{array}$ & M I5I5 & Hillgarth 567.2 (i) \\
\hline $\begin{array}{l}\text { "Libre de Tubalt" [= Història del cavaller } \\
\text { Tuglat?] }\end{array}$ & Joan d'Alemanya, tintorer & $\mathrm{M}_{4} 45^{6}$ & Hillgarth $25^{8.3}$ \\
\hline Joanot Martorell, Tirant lo Blanc & Bernat Babiloni, paraire & $\mathrm{M}_{55}{ }^{\mathrm{I} 2}$ & Hillgarth 538.4 (i) \\
\hline "romanç [en] francès... Guillem d'Englaterra" & Guillem Brinquet, estanyer & $\mathrm{V}_{\mathrm{I} 448}$ & Ferrer p. I82 \\
\hline \multicolumn{4}{|c|}{ FAULES } \\
\hline $\begin{array}{l}\text { "librum de la guineu e de la cabra" } \\
\text { [=Isopets?] } \\
\text { “romanç de Na Guineu” [= Roman de } \\
\text { Renart?] }\end{array}$ & $\begin{array}{l}\text { Guillem Andreu, paraire } \\
\text { Bernat de Montflorit, pintor }\end{array}$ & $\begin{array}{l}\text { Р г383 } \\
\text { Ма I39г } \\
\end{array}$ & $\begin{array}{l}\text { Goujaud p. I98 } \\
\text { Torras 22O.I } \\
\end{array}$ \\
\hline \multicolumn{4}{|c|}{ BOCCACCIO } \\
\hline Boccaccio, Fiameta & Miquel Castell, coraller & B I 456 & Crèdit I5I.2 \\
\hline $\begin{array}{l}\text { "lo mal dit de dones" [=Boccaccio, } \\
\text { Corbatxo?] }\end{array}$ & Jaume Rovirola, apotecari & Vi I469 & Junyent 35 \\
\hline \multicolumn{4}{|c|}{ Bernat Metge } \\
\hline $\begin{array}{l}\text { Bernat Metge, Lo somni } \\
\text { "Bernat Metge" }\end{array}$ & $\begin{array}{l}\text { Gabriel Tries, esperoner } \\
\text { Joan Granell, apotecari } \\
\text { Nicolau Deshorts, sabater }\end{array}$ & $\begin{array}{l}\text { В } 1463 \\
\mathrm{~B}_{\mathrm{I}} 5^{2} 5 \\
\mathrm{~V}_{\mathrm{I} 45^{8}}\end{array}$ & $\begin{array}{l}\text { Iglesias } 292.6^{*} / 293 \cdot 7 \\
\text { M. \& R. } 389 . \text { I } \\
\text { Ferrer p. I85 }\end{array}$ \\
\hline Bernat Metge, Lucidari & $\begin{array}{l}\text { Bernat Isern, pesador } \\
\text { Rafael Isern, pintor }\end{array}$ & $\begin{array}{l}\text { B I } 437 \\
\text { B I } 444\end{array}$ & $\begin{array}{l}\text { Iglesias I88.I4 } \\
\text { Iglesias 230.8* }\end{array}$ \\
\hline \multicolumn{4}{|c|}{ NARRATIVA EN VERS } \\
\hline Guillem de Torroella, La faula & Simó Martorell, argenter & $\mathrm{B}_{\mathrm{I} 4 \mathrm{I} 2}$ & Iglesias 53.6 \\
\hline Bernat Serradell, Testament & $\begin{array}{l}\text { Jaume Rovirola, apotecari } \\
\text { Bernat Pujol, paraire }\end{array}$ & $\begin{array}{l}\text { Vi I } 469 \\
\text { Vi I } 475 \\
\end{array}$ & $\begin{array}{l}\text { Junyent } 35 \\
\text { Junyent } 34 \\
\end{array}$ \\
\hline $\begin{array}{l}\text { Anselm Turmeda, Cobles de la divisió del } \\
\text { regne de Mallorques }\end{array}$ & Joan Talladell, sastre & B I 432 & Iglesias I $47 \cdot 3^{*} /$ I 48.5 \\
\hline $\begin{array}{l}\text { Anselm Turmeda, "Sí·s fo .I. peccador en la } \\
\text { ciutat de Catània" }\end{array}$ & Joan Noguers, barber & $\mathrm{Vi}$ I42O & Junyent $3 \mathrm{I}^{*}$ \\
\hline $\begin{array}{l}\text { "Bach" [= Disputació d'En Buch ab son } \\
\text { cavall?] }\end{array}$ & Bernat Gibert, sastre & В г 436 & Iglesias I82b.3 \\
\hline \multicolumn{4}{|c|}{ NARRATIVA SOBRE EL MÉS ENLLÀ } \\
\hline $\begin{array}{l}\text { Ramon de Perellós, Viatge al Purgatori de } \\
\text { sant Patrici }\end{array}$ & $\begin{array}{l}\text { Valença, v. Jaume Cirer, } \\
\text { cofrer }\end{array}$ & B I4I9 & Iglesias 7I.I* \\
\hline Bernat de Claravall, Visió contemplativa & Joan del Ram, cirurgià & M I452 & Hillgarth 248.I5 \\
\hline Visió de sant Joan & $\begin{array}{l}\text { Joan del Ram, cirurgià } \\
\text { Bernat Eimeric, barber }\end{array}$ & $\begin{array}{l}\mathrm{M}_{\mathrm{I} 45^{2}} \\
\mathrm{M}_{\mathrm{I} 45^{2}}\end{array}$ & $\begin{array}{l}\text { Hillgarth } 248.17 \\
\text { Hillgarth } 248.29\end{array}$ \\
\hline
\end{tabular}

Aquesta taula sistematitza la informació sobre el tema present en les principals col-leccions documentals publicades sobre llibre i lectura. L'interval cronològic considerat va des dels primers testimonis fins cap a I52O.

Abreviatures bibliogràfiques: Batlle = Batlle I969; Cifuentes $=$ Cifuentes 2ooob; Crèdit $=$ Hernando 20oo; Ferrer = Ferrer ı993; Goujaud = Goujaud 2OIO; Hernando = Hernando I995; Hillgarth = Hillgarth I99ז; Iglesias = Iglesias I996a; Junyent = Junyent I943; Madurell = Madurell I979-82; Mandingorra = Mandingorra I989; M. \& R. = Madurell-Rubió I955; Torras = Torras 2004. Les xifres indiquen els números de document i de llibre als inventaris de biblioteques publicats o bé la pàgina corresponent. 
Abreviatures geogràfiques: $\mathrm{B}=$ Barcelona; $\mathrm{G}=$ Girona; $\mathrm{M}=$ Mallorca; $\mathrm{Ma}=$ Manresa; $\mathrm{P}=$ Perpinyà; $\mathrm{S}=$ Sóller (Mallorca); $\mathrm{V}=$ València; $\mathrm{Vi}=$ Vic.

Altres abreviatures: ex. = exeunte, final; F. = Francesc; G. = Guillem; $\mathrm{m} .=$ mitjan; v. = vídua; $(\mathrm{a})=$ autògraf; $(\mathrm{i})=$ imprès; ${ }^{*}=$ explícitament en català.

Només una desena dels documents emprats en aquesta taula van poder ser coneguts per Cingolani I990-9I. Tal com adverteix al seu estudi, aquestes fonts -en particular, els inventaris i els encants- han de ser emprades amb precaució. ${ }^{9}$ No és només, com ja diu Cingolani, que una gran quantitat dels còdexs medievals fossin miscel-lanis i que aquest fet no s'hi faci saber més que excepcionalment, sinó que, més enllà d'això, cal conèixer i tenir present el conjunt dels costums dels notaris a l'hora d'elaborar els documents i la variació temporal i geogràfica d'aquells costums. ${ }^{\circ}$ Igualment, cal tenir en compte la pressa, la mecànica i el personal que intervenia en la seva confecció, els coneixements que podien tenir o no de les obres que havien de descriure o identificar i la manera com això es manifesta als documents que produïen, i, en última instància, la motivació en l'elaboració d'aquestes fonts, que no és altra que el control i la valoració d'una herència. Aquests elements en condicionen totalment la forma i, per tant, l'ús que en podem fer. Fins i tot quan es diu que tot això es té present, aquest exercici no sempre es fa i, per tant, s'oblida no tan sols que no es poden elaborar estadístiques a partir d'aquests documents -que no s'hi esmenti una obra no vol dir que no hi sigui o que no existís- sinó que la mateixa identificació de les obres inventariades depèn del presumible valor econòmic que tenien $i$, tal com s'ha dit, quan es preveia que no en tindrien s'esmentaven de manera ambigua o quedaven incloses en un conjunt sense precisions. A més, essent tot això vàlid en termes generals, s'oblida que aquestes circumstàncies afecten de manera molt dramàtica les obres en vulgar, sobretot les destinades a l'entreteniment o a la lectura plaent, i més encara en el període més valuós per a l'investigador, el més reculat. És, per tant, ben arriscat arribar a conclusions sobre els interessos literaris dels menestrals -en particular, la suposada manca d'aquests interessos- sense tenir en compte amb eficiència aquestes qüestions fonamentals.

Bo i tenint en compte aquestes qüestions, a l'hora d'elaborar aquesta taula s'han pogut constatar alguns fets o tendències sobre les biblioteques i els llibres descrits en la documentació notarial que convé analitzar críticament i que, en tot cas, una recerca més aprofundida podrà verificar. Com ja s'ha observat en altres ocasions, en general els inventaris són més explícits, amb descripcions més detallades i menys genèriques, a partir de la segona meitat del segle XIV i, sobretot, durant el segle Xv. Cert que això segurament és un reflex de l’impacte de la legislació, però la legislació

9. Per a les característiques dels inventaris i els encants, vegeu Madurell-Rubió I955: IOO*-OI*; Derolez I979; Nebbiai-Dalla Guarda I992: 32-35; Iglesias I996a: 47-58; Lencina I998; o Pagarolas 2004: 67-69. J. Hernando (I995: II-I2; i 2OOO: IO-II i 53-54) adverteix i demostra que el ventall de fonts documentals útils per a la història del llibre i la lectura no es limita a aquestes dues, que són les més assequibles i tradicionalment les més emprades. Vegeu sengles anàlisis crítiques dels inventaris, des de la història social de la lectura i l'escriptura, a Gimeno-Trenchs I992 (vegeu a continuació i la nota següent), i des de la història de la cultura (del mercader), a Aurell I996: I4O-46.

Io. Per a les característiques i possibilitats de les fonts notarials a Catalunya, vegeu Pagarolas 2004. El tema de la representativitat social que tenen els inventaris és estudiat a Cruselles 2004, que en fa un estat de la qüestió general (vegeu també Hernando 2000: 9-IO). Convé tenir present, però, que les diferents tradicions legals condicionen les valoracions. A Catalunya (Obarrio 2005; Pagarolas 2004: 67; Iglesias r996a: 47) l'obligació de fer inventari va ser regularitzada per les corts de Perpinyà de I35 I, i afectava els casos en què la titularitat dels béns pertanyia a una persona i l'administració a una altra (tutor, curador, vídua), però també quan l'hereu universal havia de restituir l'herència a tercers o quan volia assegurar el patrimoni heretat i, en general, quan algú tenia l'administració d'una herència. L'encant o subhasta es feia quan faltava líquid per a pagar els deutes deixats pel difunt i podia afectar tots o una part dels béns heretats, raó per la qual als encants a vegades no apareixen els llibres. Per a la normativa valenciana, vegeu Almenar 2018. 
respon, sens dubte, a una determinada evolució sociocultural en la qual el llibre té una difusió més i més gran, deixa de ser un producte reverencial i de luxe per a minories i passa a ser un producte quotidià i utilitari a l'abast de sectors socials cada vegada més amplis. Aquesta cronologia també és aplicable al cas particular del llibre en vulgar i sembla que, en termes generals, reflecteix el valor econòmic i social creixent que va adquirint aquest producte cultural que havia nascut a la segona meitat del segle XIII. No obstant això, cal matisar la representativitat dels inventaris, si més no en algunes temàtiques. Per exemple, encara que aquesta documentació ho reflecteixi poc, al tombant del segle XIII al XIV el llibre tècnic en català ja té una difusió que va més enllà dels cercles de la cort i de la família reial, que impulsa traduccions significatives però no pas totes les que poden situar-se en aquell període (Cifuentes 2006).

Sense deixar la cronologia, en línies generals, les biblioteques de menestrals de la primera meitat del segle XIV són d'individus amb oficis relacionats amb la cura de la salut i tenen sobretot llibres tècnics. ". A la segona meitat de segle, les biblioteques de menestrals localitzades ja pertanyen també a individus d'altres oficis, encara que en són poques i tenen sobretot llibres didàctics i religiosos. ${ }^{12}$ Durant el segle $\mathrm{xv}$, les biblioteques posseïdes per tot tipus de menestrals, generalment petites, sovintegen força més i l'abast temàtic de les obres que s’hi poden identificar és més gran. ${ }^{13}$

La coincidència cronològica d'aquests fets en diverses ciutats i de diferent grandària Barcelona, Mallorca, Manresa, Vic- fa pensar que la documentació reflecteix una tendència real: deixant de banda els oficis tècnics relacionats amb la salut, més precoços a l'hora de posseir llibres per les raons que ja s'han exposat abans, els altres menestrals devien començar a tenir petites biblioteques sobretot a partir de la segona meitat del segle XIV. En aquestes biblioteques els llibres de literatura comencen a poder-s'hi identificar principalment a partir de la dècada de I38o (vegeu la taula), tot i que aquesta impressió potser ve massa determinada per uns documents que, com s'ha dit, precisament fins a aquells anys solien ser poc generosos a l'hora de descriure els llibres, i menys encara quan eren en català. De fet, hi ha raons per pensar que els menestrals s’interessaven per la literatura ja de força enrere. En aquest sentit, les excepcions que no compleixen aquesta cronologia general, algunes de les quals visibles a la taula, indicarien una tendència que venia d'abans del que sembla. ${ }^{\mathrm{I}}$

S'han documentat alguns menestrals que posseïen llibres llatins altament especialitzats i, fins i tot, que en compraven a les subhastes. Eren llibres litúrgics, jurídics, notarials, i també formularis i registres de notaria. Aquests casos han provocat sorpresa en els investigadors, que hi han cercat diverses explicacions. Jordi Rubió, davant l'estranya evidència d'un calceter de Barcelona que l'any I 490 posseïa un llibre de dret canònic, pensà que la família devia tenir algun lligam amb canonistes (Madurell-Rubió I955: doc. 69; vegeu el cas d'un altre calceter de Mallorca a Hillgarth I99I: doc. 8I2). Més recentment, Toni Iglesias ha documentat altres casos semblants, en particular

II. A Barcelona, l'única localitzada és la del cirurgià del rei Bernat Serra, el I338, amb llibres mèdics, religiosos, enciclopèdics i de filosofia natural (Hernando I995: doc. 76). A Mallorca, hi ha les d'un cirurgià, el I348, i d'un apotecari, el I349, una i altra només amb llibres tècnics (Hillgarth I99I: docs. 42 i 46 ). Hi ha dues excepcions a aquest aparent domini dels oficis sanitaris, a València (Mandingorra I989: doc. 3 i ro): un fuster de I325, que tenia llibres tècnics, i un draper de I34I (Jaume de Benages, a la taula).

I2. La d'un paraire de I363 és la següent a Barcelona (Hernando I995: doc. 240). A Manresa, la primera biblioteca d'un menestral que s'ha localitzat és de I368 (Torras 2004: doc. II6), però, malauradament, els documents manresans tendeixen a ser poc explícits.

I3. "Es tracta, en la seva majoria, de llibres en llengua catalana, de baix preu, de contingut literari, religiosodevocional i gramatical. Aquests són els trets remarcables de les seves biblioteques” (Iglesias I996a: 205, per a Barcelona).

I4. Tinc en preparació un altre treball sobre unes peces literàries copiades per un menestral de la primera meitat del segle XIV. 
pellers i, sobretot, sastres, que compraven aquest tipus de llibres en certa quantitat, i suposa que feien paral-lelament de llibreters o bé que els adquirien per als seus fills, que s'estarien formant en aquelles professions (Iglesias I996a: 2OI-O2; Iglesias I996b: 383, 385).

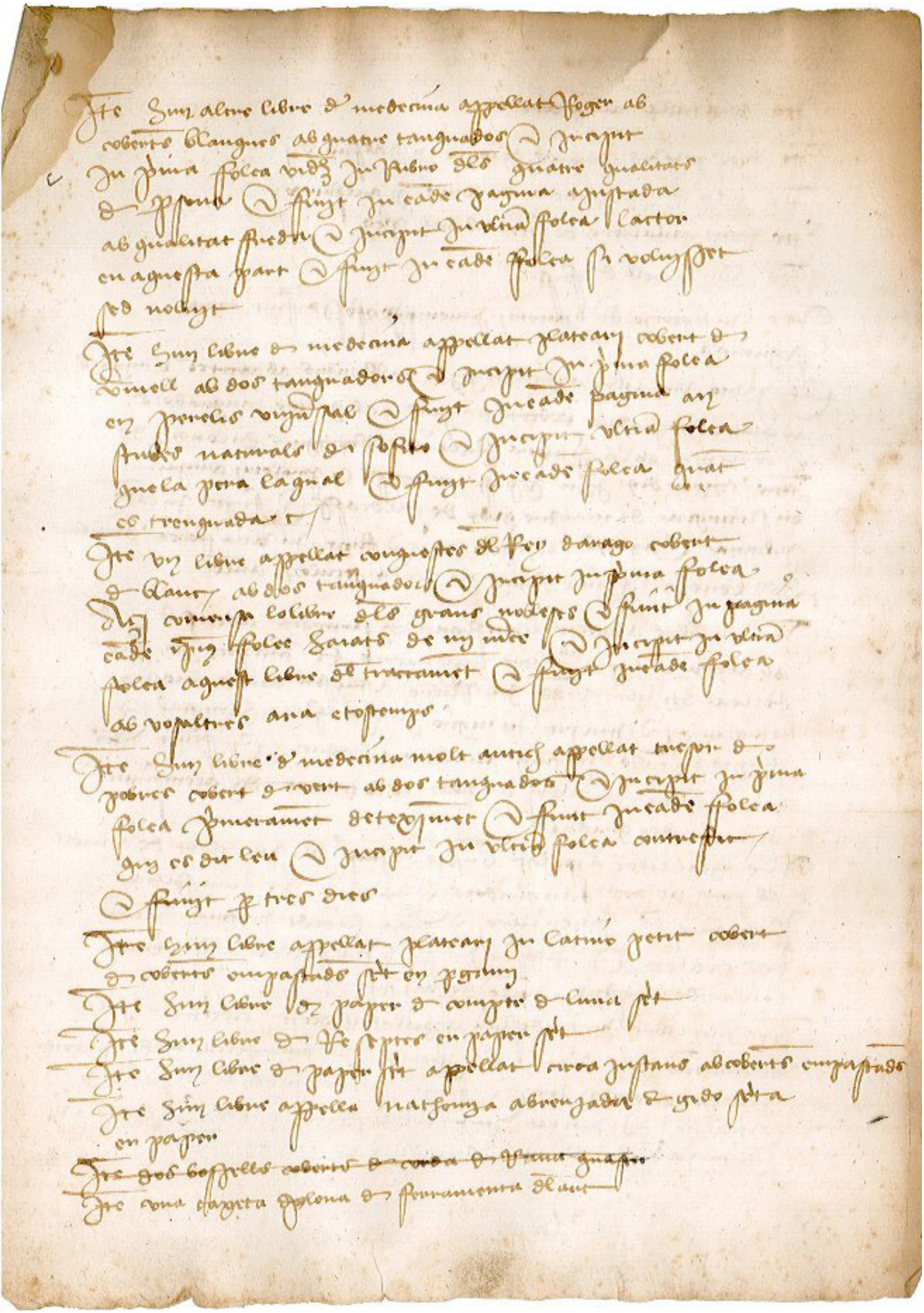

Fig. I: la Crònica de Bernat Desclot entre els llibres de cirurgia d'un barber-cirurgià de Perpinyà anònim de mitjan segle XV (@) ADPO, Arxius notarials, 3 EI/I6IO; vegeu Sciència.cat DB doc78). 
Tot i que no es poden descartar aquests extrems, en particular que alguns menestrals es dediquessin paral-lelament a la compravenda de llibres, des de la publicació de la important col-lecció documental de Josep Hernando (2000) sobre l'ús del llibre com a garantia creditícia, sobretot de censals i violaris, i sabent la importància del crèdit a la societat urbana medieval (Vela $2007 \mathrm{~b})$, sembla que la interpretació ha de ser una altra: aquests llibres llatins, i més encara els especialitzats, tenien un valor molt més elevat que els llibres en vulgar i, adquirint-los, el que feien aquests artesans era una inversió de futur, garantint-se la possessió d'un bé molt valorat amb el qual podien entrar al mercat del crèdit. ${ }^{15}$ Això explicaria la passió que pels llibres de dret llatins tenien tants menestrals (Hernando 2000: doc. 39, 68, 256, 453, 455, 5II, 537). En aquesta extraordinària col-lecció documental, els llibres emprats com a garantia del retorn dels préstecs són sobretot en llatí, principalment de dret i litúrgics i, a distància d'aquests, de medicina i d'autors clàssics. Els menestrals hi són molt presents, però com es pot comprovar a la taula, només dos posen com a garantia obres literàries en vulgar -de Boccaccio i d'Enric de Villena-, mentre que els altres empren per a aquest objectiu llibres llatins d'altres temàtiques, sobretot de dret. No obstant això, aquesta atracció que demostraven tenir els menestrals pels llibres és altament significativa.

\section{Menestrals 'copistes'? Els llibres autògrafs}

$\mathrm{U}$ $\mathrm{n}$ altre fet documentat entre els menestrals, que no era estrany en el medi urbà en general (Hillgarth I99I: 250-52; Iglesias I996a: 316-3I), és la manufactura de còpies autògrafes dels llibres que els interessaven. Als inventaris de béns, els notaris, en descriure els llibres, a vegades n’informaven ("scrit de mà del dit deffunt") i els llibres copiats no es limitaven als relacionats amb l’ofici. És una particularitat que no es detecta únicament a les atestacions documentals sinó també als manuscrits conservats. A l'hora d'interpretar-la, però, s'ha estat víctima de confusions, tant derivades de l'ús ambigu del mot 'copista' per referir-se a aquests individus als estudis com del grau de coneixement de la història cultural d'aquests sectors; unes confusions que no han permès copsarne la importància real. En efecte, no eren en absolut professionals de la còpia de llibres, ni s'hi dedicaven puntualment per complementar els ingressos, sinó gent que s’estava procurant còpies d'unes obres, que valorava de manera molt especial, per al seu ús privat. Aquesta gent no pertanyia només a l'elit urbana -patriciat i mercaders- o a les professions amb una formació intel-lectual i escripturària superior -notaris, juristes, metges-, sinó també a les capes inferiors de la burgesia. Els individus d'aquest sector social fins i tot podien elaborar traduccions, adaptacions o comentaris de les obres que els interessaven, i desitgen, intencionadament, no romandre en l'anonimat. Es tracta, doncs, d'un fenomen d'una importància cultural extraordinària, que només darrerament es comença a entendre i a tractar com es mereix (Martí 202I). ${ }^{16}$

I5. Hernando (2O00: 9-IO) apunta que aquests documents no informen sobre els interessos culturals dels individus contractants ni sobre la importància de les col-leccions que es reunien d'aquesta manera, sinó sobre el valor econòmic que s'atribuïa a uns o altres llibres i a les obres que contenien. L'apreciació em sembla molt pertinent, però caldria matisar que el valor econòmic que s’atribuïa a unes obres o altres sí que podia estar en relació amb els interessos culturals vigents i amb determinades tendències dels i de les quals els contractants eren conscients.

I6. En els exemples que segueixen aporto també una transcripció diplomàtica dels colofons i d'alguns altres fragments a fi d'evidenciar la cultura escripturària d'aquests individus. 

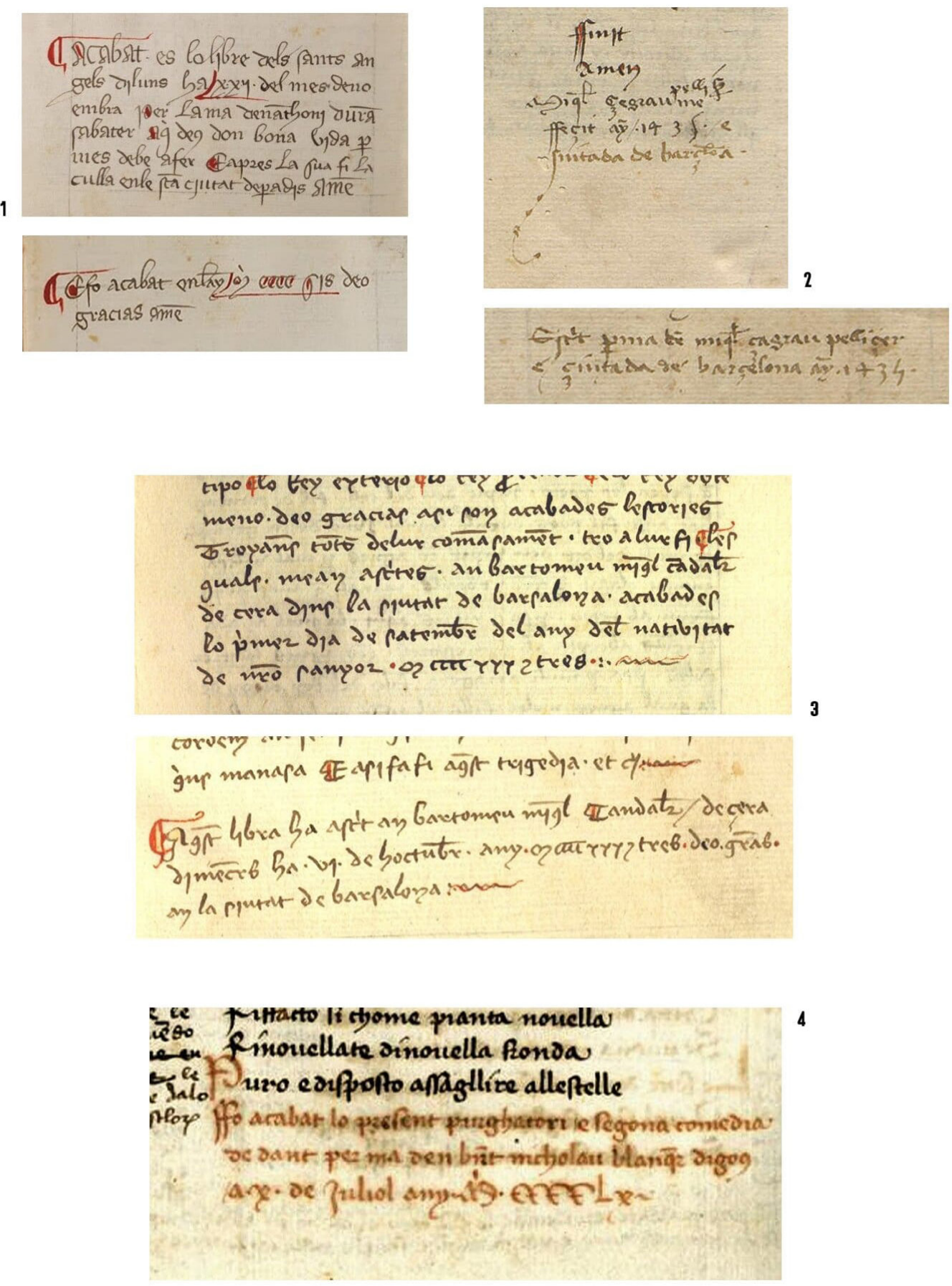

Fig. 2: colofons autògrafs de: I. Antoni Duran, sabater, I4O6 (C BC, ms. 267, ff. 29OV-29Ir);

2. Miquel Sagrau, pellisser, I 435 (CCo BRUB, ms. 79, ff. 362v-363r);

3. Bartomeu Miquel, candeler, I433 (C ACB, Còdexs, I2, ff. I77r i 264r);

4. Bernat Nicolau, blanquer, I46o (@ HSA, ms. HC397/688, f. 74v). 
2.I El Guillem Reixac de la Història del sant Graal

Una de les obres presents a la taula, la traducció catalana de La Queste del saint Graal, ofereix un bon exemple general del que s'ha dit. La Història del sant Graal es conserva en un únic manuscrit que acaba amb un colofó datat en l'any I380 en el qual apareix el nom d'un cert Guillem Reixac:

Aqast lebre és d'en Guillem Rexach, lo qual l’à escrit hi acabat dimecras a .XVI. yorns de mayg de l'any .M.CCC.LXXX.

[Transcripció diplomàtica:] Aqaft lebre ef den · Guillem · Rexach | lo qual la efcrjt hi acabat djmecras | a.xvj. yorns de mayg de . lany $\cdot \mathrm{M} \cdot \mid \operatorname{ccc} \mathrm{xxx}^{\mathrm{r}}$

Les alteracions que es detecten en aquesta traducció o adaptació provarien que s'hauria efectuat en un ambient de franciscanisme militant (Adroher 2005-o6, per al qual aquestes alteracions en farien més aviat una adaptació), però el paper exacte de Reixac en la transmissió de l'obra continua sent controvertit: mentre per a Adroher (2005-06: 86) va ser el traductor de l'obra al català i alhora el 'copista' ("scribe") del manuscrit conservat, Santanach (20IO: 24-25) hi veu només l'autor d'aquesta còpia, ${ }^{18}$ opció que confirmaria una lectura literal del colofó, on Guillem només diu haver copiat ("escrit"), i la mateixa llengua, més antiga que el testimoni conservat. La presència de la scripta librària catalana primitiva (Badia-Santanach-Soler 20ıо) situa la traducció cap al regnat de Jaume II (I29I-I327), durant el qual és més entenedor aquell franciscanisme militant. L'anàlisi lingüística del testimoni, en el qual, com s’ha vist al colofó, la grafia s’aparta de la convenció culta i reprodueix la fonètica, situa a Mallorca si més no la còpia supervivent, feta per un individu que no tenia una formació escripturària superior i que, per això, produí un text amb unes lliçons tan particulars (per a Crescini-Todesco I9I7, és una còpia "disattenta” [XLIV], obra d'un "copista" mallorquí amb "scarsezza di cultura" [LIV, LXVII]).

Qui era, però, i quin perfil tenia aquest Guillem Reixac? Els estudis sobre aquesta obra no han aconseguit identificar-lo. Som davant d'un problema derivat de la compartimentació disciplinària, perquè els historiadors porten molts anys publicant dades sobre aquest personatge, per bé que tampoc no l'han relacionat amb l'autor del manuscrit. Així, Maria Teresa Ferrer i Carles Vela (2OI4: doc. 349) han regestat un document de I398 en el qual un Guillem Reixac, ciutadà de Mallorca, interactua amb diversos mercaders. L'apel-latiu genèric 'ciutadà', quan apareix sense cap concreció de l'activitat habitual del personatge, sol fer referència als membres del patriciat o oligarquia urbana, però també - per lògica numèrica, més sovint- als sectors més acomodats de la burgesia, d'emprenedors o rendistes, que no en formaven ben bé part. En efecte, Guillem Reixac era un patró de nau mallorquí, documentat des d'almenys I37I (Dufourcq 1974: doc. 5-6), que el I385 va exercir un càrrec tan relacionat amb l'activitat marítima com era el de cònsol de mar de Mallorca (Garcia Sanz I968: 637). ${ }^{19}$ Aquesta categoria social, no pertanyent a l'oligarquia, permet entendre el poc

I7. Milà, Biblioteca Ambrosiana, ms. I. 79 Sup., f. r3ovb. Aquest colofó ha estat publicat, entre d'altres, per CresciniTodesco I9I7: 206, primers editors d'aquesta traducció (que aporten un facsímil d’aquest foli a la p. [LXXI] $\underline{\text { https:// }}$ tinyurl.com/3fvggavk>, a partir del qual es transcriu aquí); Hillgarth r99г: doc. IO4; Adroher 2005-o6: 86, en nota; Gimeno 2007: 336; i Santanach 20I0: 24. Adroher hi transforma els numerals en xifres aràbigues i Hillgarth hi regularitza l'ortografia. Com ja ha indicat Adroher (2005-06: 86), les còpies de les dues obres presents al manuscrit són d'una mateixa mà.

I8. Miquel Adroher ha detectat passatges que el traductor havia oblidat de traduir i que tradueix més endavant, en el punt de connexió dels quals hi ha frases repetides que es tradueixen de manera diferent. Santanach hi detecta errors de còpia. Per a Crescini-Todesco I9I7: XLIV, LIV o LXVII, va ser "copista".

I9. El còdex del segle XIV del Llibre del Consolat de Mar, el més antic que es conserva, fou elaborat durant el seu 
domini de la norma gràfica culta per part seva alhora que explica per què, tal com ja es veu a la taula, el cercle de difusió d'aquesta obra no es va limitar a l'elit social, com pensa Adroher (2005-06: 79, 8I), sinó que va ser força més ampli. D’altra banda, aquest cas dona una pista per interpretar què eren els 'mariners' que apareixen a la taula, una expressió que devia encobrir individus d'un perfil similar al de Reixac ${ }^{20}{ }^{2}$ 'interès dels quals per la literatura podia incloure la manufactura de còpies autògrafes. Reixac, però, tot i no formar part de l'oligarquia urbana no era tampoc un menestral. ${ }^{2 \mathrm{r}}$

\subsection{Eiximenis, copiat de mà de menestrals}

A les biblioteques dels menestrals, dues de les obres de Francesc Eiximenis semblen ser les més copiades 'de mà del difunt'. Així, un sastre de Barcelona posseïa l'any I 436 un Llibre dels àngels d'aquestes característiques (Iglesias 1996a: doc. I82bis.r; Hernando 2007: doc. 24), i el balancer de la seca de la mateixa ciutat Guillem Garriga, consignat a la taula per altres obres de la seva biblioteca, inventariada l'any I46I, un Llibre de les dones també escrit de pròpia mà (Cifuentes 2ooob: doc. I.4; Hernando 20O7: doc. 57) ${ }^{22}$ Però aquesta mena d'individus no s'autocopiaven només obres d'Eiximenis. El mateix balancer es copià un llibre d'oracions (Cifuentes 2ooob: doc. I.I4) -una tipologia que, com la dels receptaris mèdics (Cifuentes 20I6) i els reculls utilitaris de caràcter miscel-lani (Cifuentes 2O2I), era molt afectada per aquest procediment de transmissió-, i l'apotecari mallorquí Alemany d'Espanya 'esmenà', almenys, la còpia d'un exemplar de la Història del sant Graal per a un prevere el I4I5 (Hillgarth I99I: doc. I75; i abans Llompart 1975-77: 63; vegeu taula). D’altra banda, encara que el notari no ho especifiqués, és possible que alguns volums incomplets i sense relligar que hi ha en alguns inventaris tinguessin aquest mateix caire, com ara els "..III. qüerns del libre de Tristany" que tenia l'argenter de Barcelona Romeu Desfeu l'any I4I9 (també a la taula). ${ }^{23}$

mandat en aquest any: "Lo present Libre de Capítols del Consolat de Mallorques fo comensat en l'any de la nativitat de nostre Senyor .m.cCc. huytanta sinch, estans cònsols en lo dit ayn los honrats En Guillem Rexach, patró, e (...) Pont, de la Lotge, mercader, e finat e acabat a .xx. e tres de mars del dit ayn...” (Palma, Biblioteca Balear del monestir de Santa Maria de la Real, ms. S.C.-Ar. 2, f. ıIv, a partir de Garcia Sanz ı968: 637; també a Colon-Garcia 2oor: 966).

2o. Vegeu, per exemple, els "Capítols fets, concordats e avenguts entre lo honorable N’Anthoni de la Sorba, mercader, del loch de Ciutadilla de la illa de Manorque, de una part, e En Ffrancesch Porch, mariner, ciutadà de Barcelona, senyor e patró de una calavera [sic] de un thimó e una cuberta appellada 'Sancta Crestina', la qual are és en la playa de l'arenal de la mar de Barcelona, de la part altre, de he sobre lo noliegament que lo dit patró fa al dit mercader de la dita sua calavera per e en la forma e manera qui.s segueix..." (AHPB, 2O4/2, bossa, s/n, I2/O6/I458).

2I. Encara menys ho era, i per això queda fora d'aquest estudi, un altre patró de nau relacionat amb la literatura: el poeta Melcior de Gualbes del Cançoner Vega-Aguiló (fl. Barcelona I395-I4I5), membre d'aquesta família de l'alta burgesia barcelonina (Torró 20I4: 302-O5 en fa un estat de la qüestió; Anna Alberni en prepara una nova aportació).

22. L'inventari i l'encant posterior del balancer també són a l'apèndix d'Iglesias I996a (doc. 286 i 287), però no hi identifica totes les obres i n'omet els llibres de comptes.

23. Del Tristany en català se'n conserven només fragments de còdexs, un dels quals, precisament, sembla que mai no va ser relligat (Santanach 20IO: 30-3I) i, per la impaginació que té, que recorda els registres notarials, Soriano (20I3: paràgrafs 26-27) proposa atribuir-lo a un notari. Convé recordar, però, que aquest format també era el que resultava més familiar a tot tipus de públics urbans. D’altra banda, tot i que les traduccions del Tristany i el Lancelot s'originessin, molt probablement, a l'entorn del monarca, "els mateixos manuscrits que ens n'han arribat, sobris i ben poc ornamentats, posen de manifest que aquestes obres van circular per sectors socials molt diversos, ja fos en francès o traduïdes, i que en cap cas no van constituir un patrimoni exclusiu dels cercles nobiliaris i més benestants" (Santanach 2OIO: 24). No tan sols la taula adjunta evidencia la part que toca als menestrals en aquesta observació, sinó també l'antroponímia, ja que aquesta novel-la sembla ser l'origen del nom del barber-cirurgià de Barcelona Lleonís Mestre, mort l'any I437 (Roca I923-24, malgrat transcriure "Leonis" a l'inventari, l'anomenà "Leonci” al comentari; vegeu Sciència.cat DB doc209). Altres casos d'antroponímia similar, en persones i animals de la cort, a Rubió I9o8-2I: II, 327 i Adroher 2005-06: 80. Per als mercaders, vegeu infra el capítol 4, Literatura i promoció social (nota 54). 
El manuscrit de Guillem Reixac no és l'únic conservat d'aquestes característiques, com es pot comprovar a la llista de colofons publicada per Gimeno (2007), en la qual també s'evidencia la predilecció per Eiximenis, en concret per les mateixes obres que es detecten als inventaris. Gimeno recull el cas del pellisser de Barcelona Miquel Sagrau, que va copiar un dels exemplars supervivents del Llibre de les dones l'any I435, i els de tres menestrals més de la mateixa ciutat -un sabater, Antoni Duran, un altre pellisser, Joan Espanya, i un esparter, Jaume Vilardell- que van transcriure de la pròpia mà tres dels còdexs conservats del Llibre dels àngels en els anys I406, I409 i I486, respectivament (Gimeno 2007: núm. I8, II, I2 i 35; alguns d'ells citats abans per Renedo I993: 220). ${ }^{24}$

Les dades que es coneixen sobre aquests individus dibuixen perfils de personatges benestants, dintre de la menestralia. El I 437 el pellisser Miquel Sagrau era marmessor de l'esposa d'un 'pagès', ciutadà de Barcelona, que segurament era un propietari agrícola, i una de les dues cases que aquesta dona posseïa a la ciutat fou adquirida per Eulàlia, l'esposa de Sagrau (Ferrer I998: 293; Martí 2O2I). El I44O, Sagrau arrendà la farneria -dret sobre el pes de la farina- de Barcelona (Sánchez I993: 404, 423). És possible que el blanquer homònim que el I463 tenia un plet a la cúria reial (Sobrequés I978: núm. 360-6I) fos el mateix individu (Martí 2O2I), però no sembla identificable amb un actiu mercader contemporani d'aquest nom. En els anys I405-o6, el pellisser Joan Espanya estava casat amb Margarida Burguet, filla d'un 'pagès', ciutadà de Barcelona, i germana d'un prevere beneficiat a la catedral (Mañé-Rovira 2005-I3: III, doc. 997). Margarida era un costurera reconeguda, perquè el I398, quan ja estava casada amb el pellisser, va ser requerida, sota contracte, per la reina vídua Violant de Bar perquè ensenyés l'ofici, durant vuit anys, a una seva esclava negra de set o vuit anys anomenada Llúcia (Hernando 2003: doc. 823, on diu "peller" i no pellisser per error). L'esparter Vilardell no s'ha pogut documentar, però probablement era parent d'altres menestrals i mercaders barcelonins d'aquest nom.

Però és especialment interessant el cas del sabater Antoni Duran perquè és testimoni d'una clara promoció personal. Antoni Duran havia estat esclau del també sabater de Barcelona Bernat Duran. Quan aquest va fer testament ( ${ }_{3} 67$ ), va decidir concedir-li la llibertat, però l'esclau devia ser molt jove, perquè aquell li va imposar la condició d'aprendre l'ofici de sabater durant quatre anys. Els marmessors del difunt el van lliurar al sabater de la ciutat Jaume Sanç, que el va formar, i finalment va ser alliberat (I37I). ${ }^{25}$ És ben probable que Sanç no el formés únicament en la sabateria, sinó també en la lectura i l'escriptura, un ventall formatiu que no era estrany en els contractes d'aprenentatge (Hernando 2005; Martí 2O2I). A diferència dels altres casos esmentats, en la còpia que Duran va fer-se del Llibre dels àngels demostra ser menys coneixedor de les maneres d'elaborar un llibre formal i, també, tenir més aviat poca familiaritat amb la norma gràfica del català més o menys generalitzada a l’època (Martí 202I); $;{ }^{26}$ uns trets que retenim, perquè els retrobarem

24. Els còdexs, per l’ordre que han estat citats, són BRUB, ms. 79; BC, ms. 267; Escorial, ms. h-II-I6; i BPEB, ms. 400 (Gimeno 2007 dona signatures errònies per a aquests dos últims; les correctes, a Eiximenis DB; els colofons dels dos primers, a les fig. 2.I i 2.2). Martí 2O2I (treball en premsa que he pogut llegir per gentilesa de l'autor) interrelaciona les característiques codicològiques d'aquests manuscrits amb l’alfabetització dels menestrals, un plantejament de gran interès per al tema i del tot complementari amb el que s'exposa en aquest article.

25. L'acta de manumissió és a AHPB, 28/4 (Ramon de Massana), ff. 3v-4r, 9/O4/I37I, citada a Hernando 2003: I4I, en nota, que no relaciona el personatge amb el ms., com tampoc ho fa la bibliografia eiximeniana. S'hi esmenta el testament de Bernat Duran, fet davant el mateix notari el Io/o2/ I367, però no se’n conserven protocols d'aquesta data. També s'hi esmenta l'acta per la qual els marmessors testamentaris de Duran van encomanar l'esclau Antoni a Jaume Sanç, amb l'acceptació d'aquest, que és registrada a AHPB, 28/I (Ramon de Massana), f. I4rv, I3/O5/I367. En aquests documents no s'esmenta la nacionalitat d'origen d'Antoni Duran.

26. Precisament, Badia-Martí (2OI3: 42) posen aquesta “còpia rude” com a exemple del fenomen de l'autoproducció de llibres. 
a continuació, en particular l'últim, en l'obra del candeler Bartomeu Miquel. El colofó que l'antic esclau va afegir a la seva còpia (vegeu fig. 2.I), que declara iniciada “digous a .XV. de joliol, l'any .M.CCCC. sis", fa així:

Acabat és lo Libre dels sants àngels diluns ha .XXII. del mes de noembra per la mà de N'Anthoni Duran, sabater, a qui Déus don bona vida per més de bé a fer e aprés la sua fi l'aculla en le sancta ciutat de paradís. Amén. E fo acabat en l’any mil .cccc. sis. Deo gracias. Amén.

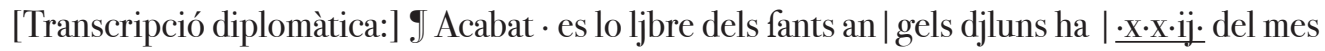
deno | embra Per la ma denanthonj duran | fabater aqui deus don bona vjda per | mes debe afer Eapres la fua fi la | culla enle fancta cjutat deparadjs Amen | | I Efo acabat enlany | Mil cccc fis deo | gracias ame $n^{27}$

L'interès que els menestrals tenien per aquestes obres d'Eiximenis se sumava al que tenien pel Crestià, especialment el Dotzè, que, a part d'oferir una summa del saber, actuava com a legitimador ideològic dels estrats urbans. N’hi ha prou, per comprovar-ho, amb consultar els índexs de les col-leccions documentals emprades en aquest treball i també el recull publicat per Hernando (2007: 427-3I) per a la Barcelona del segle XV. És probable que la fal-lera per aquestes obres d'Eiximenis, en particular pel Llibre dels àngels, també estigués relacionada amb l'aprenentatge de lletra. ${ }^{28}$

\subsection{Les Històries troianes del candeler Bartomeu Miquel}

Encara és més interessant, perquè afecta una de les obres consignades a la taula i per les característiques de la còpia i del menestral, el cas del candeler de cera de Barcelona Bartomeu Miquel, que el I433 es copià un manuscrit que conté les traduccions catalanes de la Historia destructionis Troie de Guido delle Colonne -una obra que es llegia com un romanç (Cingolani I990-91: 99-I05; Wittlin 1995: I88) i que, en feliç expressió de Llompart (1975-77: 204), "presenta l'epopeia grega en cota de malla medieval" ${ }^{29}$ i i d'una part de les Tragèdies de Sèneca. ${ }^{30}$ Un manuscrit miscel-lani, per tant, com ja sabem que ho eren molts, tot i que els inventaris no ho reflecteixin.

El Bartomeu Miquel d'aquest còdex és un personatge perfectament identificable. Aquest candeler de cera -rang superior i més benestant de l'ofici, per damunt dels candelers de seu- era fill d'un reboster homònim, i tenia quatre germans, que, deixant de banda la noia, van ser reboster, mercader i candeler de cera. Apareix per primera vegada a la documentació conservada el I408, exercint el seu ofici. Aquest any cobrava uns ciris que havia proporcionat per al funeral de Francesc

27. BC, ms. 267, ff. 29Ov-29זr, publicat per Gimeno 2007: núm. II, i Martí 2O2I. Aquí es transcriu a partir d'una reproducció que agraeixo a Sadurní Martí. Els calderons i els subratllats són en vermell, tinta amb la qual també va afegir alguns tocs a les majúscules.

28. A l'inventari d'un jurista de Mallorca de I446 apareix un llibre “apellat Dels àngels, lo qual libre En Miquel, fill del dit deffunt, aprèn” (Llompart 1975-77: 222; Hillgarth I99г: 247 i doc. 222.2).

29. Vegeu-ne quatre testimonis del segle XV a la taula. Per al que s’identifica només amb l'al·lusió “Troyà”, vegeu la petició de Joan I a Rubió I9o8-2r: I, doc. 273; i els nombrosos testimonis citats per Perujo (20I5: 9, 6o, 74, 92, 94-99), als quals convé afegir el de l’inventari del mercader de Barcelona Francesc d’Altelló: “Ítem... Troyà en pla, qui comença ‘Jatzsia que tot dia' etc., lo qual és d’En Mir, mercader”, íncipit que correspon al del pròleg de l'autor en la traducció catalana de l'obra (ACB, Llibres extravagants, Inventari de Francesc Daltell [=d’Altelló], mercader de Barcelona, I42O23 , f. I8r).

30. Les “Tragèdias de Sènecha, en pla”, també van atreure l'atenció dels paraires (Hillgarth I99I: doc. 24I.5, inventari de Joan Piris, Mallorca, I45). 
Benejam, patró de barca de Barcelona. Una de les marmessores del difunt era vídua de Francesc Miquel, patró de nau, i, d'altra banda, va rebre un altre pagament de la mateixa marmessoria un cert Pere Miquel, ecònom del convent dels framenors. Tot i que no es precisa, aquests individus i oficis podrien representar una part del cercle familiar i social del candeler en aquells anys. Sí que consta que vivia al quarter de Framenors de la ciutat i que estava casat amb Violant Pere, filla d'un hostaler. Bernat, el germà candeler, va enllaçar amb una família de mercaders i, finalment, havent millorat la seva posició social, abandonà l'ofici (Madurell I949-52: VII, reg. 8 i 498; Vela 2007a: 3I4, 338-39; Bernat també a Hernando 2000: doc. 38-39, de I432, on es diu que ja no feia de candeler). El I445 Bartomeu Miquel devia ser un membre destacat del seu gremi. El seu nom consta el primer d'entre els candelers de cera a la llista dels menestrals elegibles per al Consell de Cent creada arran de la reforma de I445. Aquesta llista té anotacions sobre els viatges o la defunció dels individus fins a l’any I 452, i en el cas de Miquel sí que hi consta la menció “òbit” afegida al costat, però sense data (Batlle I973: 58I). Atès que el I449 encara era viu, perquè s'esmenta al cens d'aquell any, s'ha de situar la seva mort entre aquesta data i $145^{2.3^{3}}$

Al final de cadascuna de les dues obres copiades al manuscrit, en dos colofons, Bartomeu Miquel va voler deixar constància, expressament, de la seva tasca, precisant-hi amb orgull el seu ofici (vegeu fig. 2.3). ${ }^{32} \mathrm{Al}$ colofó de les Històries troianes sembla que es va permetre el joc de personificar l'obra:

Deo gracias. Así són acabades les [Es]tories troyanes, totes, de lur comansament tro a lur fi, les quals me an ascrites an Bartomeu Miquel, candaler de cera, dins la siutat de Barsalona. Acabades lo primer dia de satembre de l'any de la nativitat de nostro Sanyor .M.CCCC.XXX. e tres.

[Transcripció diplomàtica:] · deo graciaf afi fon acabades leftorjes | Troyanes totes delur comanfament · tro a lur fj I lef | qualf · mean afcrites · an bartomeu mjquel candaler | de cera djns la fjutat de barfalona $\cdot$ acabadef | lo primer dja de fatembre del any dela nativjtat | de nostro fanyor $\cdot \mathrm{M}$ cccc Xxx $e$ tres .

Al final del manuscrit i de la copia parcial de les Tragèdies, Miquel va tornar a deixar constància del seu esforç:

Aquest libra ha ascrit an Bartomeu Miquel, candaler de çera, dimecres ha.VI. de hoctubre any .M.CCCC.XXX. e tres, Deo gracias, an la siutat de Barsalona.

[Transcripció diplomàtica:] I Aqueft ljbra ha ascrit an bartomeu miquel Candaler / de çera I djmecres ha · vj · de hoctubre · any · м cсcс xxx e tres · deo gracias · I an la fiutat de barfalona ·

Tant en aquests colofons com al text, Miquel evidencia un domini suficient de la tècnica escripturària, però un coneixement francament limitat de les habituds gràfiques cultes, menys

3г. Sobre aquest candeler, vegeu AHPB, 58/I79, f. IIIv (23/o3/I408), venda de candeles; AHPB, 54/I7, f. $65^{\mathrm{r}}$ (20/8/I4IO), amb la seva sogra Maria, vídua de l’hostaler Martí Pere; AHSCSP, Protocols notarials, Joan Torró, Manual quart, f. 7v (28/7/I4II), venda de candeles; AHPB, IO $/$ IIO, ff. 43V-43bisr (I5/2/I4I I), marmessor testamentari d'un sastre de la seva família; AHPB, II3/99, ff. I42V-I44r (II/4/I432), beneficiari en un testament d'una familiar; i AHCB, Consell de la Ciutat, Fogatges, XIX.7 (9/I449), censat a Barcelona. Agraeixo a Carles Vela que hagi tingut l'amabilitat de proporcionar aquesta documentació.

32. ACB, Còdexs, I2, ff. I77r i 264v, transcrits del manuscrit, amb els calderons en vermell, i alguns tocs de la mateixa tinta i de safrà en majúscules, calderons i altra decoració. Han estat publicats per Miquel I9I6: XXI (tots dos) i Martínez r995: I, 77-78 (el darrer, amb la data errònia), entre d’altres. Les descripcions del còdex més destacables són les de BITECA manid I426 (on la identificació del Bartomeu Miquel d'aquest còdex amb un homònim que era escrivà $i$ causídic de Barcelona no és correcta) i, en particular, Perujo 20I5: I27-30. 
encara que el sabater Duran abans esmentat. ${ }^{33}$ Bartomeu Miquel, però, va considerar que havia de posseir aquestes obres, que havia de copiar-les en un llibre minuciosament elaborat amb els trets formals que pertocaven i que aquesta tasca no havia de quedar en l'anonimat sinó que hi havia de mostrar, orgullós, el seu nom i, significativament, el seu ofici.

En efecte, el còdex aconsegueix transmetre la impressió de formalitat, amb els plecs marcats amb reclams, foliació, índex inicial, impaginació correcta (text a línia tirada però amb marges rectes, pautats), lletra acurada (cursiva amb tendència a la semicursiva, amb discretes prolongacions florals als marges superior i inferior), i ornamentació regular i vistosa, segurament de mà d'un professional (caplletres afiligranades en tres colors, la primera més gran, rúbriques i calderons vermells, tocs de vermell i safrà en majúscules i de safrà als calderons, traços horitzontals de complement de línia, reclams, foliació, marginàlia i prolongacions de les lletres sovint en vermell); professional que també devia preparar el còdex. Als marges té anotació i manetes que segurament vénen de l'antígraf, a vegades amb color, i una altra de feta per una mà del segle XVI, molt probablement d'un clergue que adquiriria el manuscrit i el cediria a l'ACB, que escriu en català i en llatí. Aquestes característiques s’adiuen amb les dels manuscrits eiximenians copiats per menestrals que fa notar Martí (2O2I).

Bartomeu Miquel pertany a un entorn sociocultural que se sent ufanós d'un aprenentatge escripturari que li obre tot de possibilitats inèdites, i no és estrany que una mà coetània -potser sí la d'un fill, com va aventurar Wittlin (I995: I82) - volgués deixar testimoni d'aquest esforç en una anotació als folis en blanc del final (vegeu fig. 3) en la qual proporciona dades precioses que concorden amb les publicades per Hernando (1993-97 i 2005) i les complementen:

Qui [n]a vol aprendre, [si es] vol, de legir re e de asscriura, vaga [a] apre[n]dre a casa de mestre Català e n’a[n]sayar-vos à per cotra fflorins ffins que·n sàpia, he y n ne y costa [sic per he no y costa].

[Transcripció diplomàtica:] Quja vol aprendre vol de legirre e de affcriu | ra vaga a predre aca fa de meftre catala ena | fayar vosa per cotra fflorins ffins que $\mathrm{n}$ fapia | hey N Ney cofta ${ }^{34}$

Aquest "mestre Català" potser era el "Joan Català, scrivent de letra rodona", que el i46i retenia un Llibre dels àngels del balancer Garriga (Cifuentes 200ob: doc. I.I7). En qualsevol cas, era un dels nombrosos mestres d'escoles privades que van proliferar en aquell context urbà dels segles XIV i XV en el qual més sectors socials dels que s’ha suposat desitjaven tenir una formació que fos útil per a la seva vida quotidiana i també per a la seva promoció social. Els treballs de Josep Hernando (I993-97 i 2005, en particular) sobre l'ensenyament a Barcelona n'aporten una gran quantitat d'informació. Per als menestrals que s'ho podien permetre, pagar un mestre privat era una de les vies possibles. Altrament, també tenien a l'abast les escoles de la catedral i de la ciutat, que diversos municipis van fer per crear i mantenir, o bé, si els recursos eren menors, podien optar per contractes d'aprenentatge dels seus oficis que incloguessin la formació en lletra. Fa l'efecte, gràcies al valuós testimoni d'aquesta anotació, que a casa de Bartomeu Miquel sí que es van poder permetre pagar un mestre privat.

33. Per a una extensa mostra de l’ortografia fonètica de Miquel, vegeu Perujo 20I5: III.

34. ACB, Còdexs, I2, f. [266]v, transcrita del manuscrit. Només ha estat indicada i publicada (amb errors) per Wittlin (I995: I83, que la va interpretar com l'‘anunci publicitari’ d’un mestre d'escola) i BITECA manid I426. A sota hi ha proves del traç d'algunes lletres, al costat d'un matusser dibuix floral, al foli anterior (f. [265]v) hi ha uns alfabets complets i al següent (f. [267]r) un proverbi o sentència a mig copiar (“Bondat hés bona”), tot de la mateixa mà que l'anotació. 


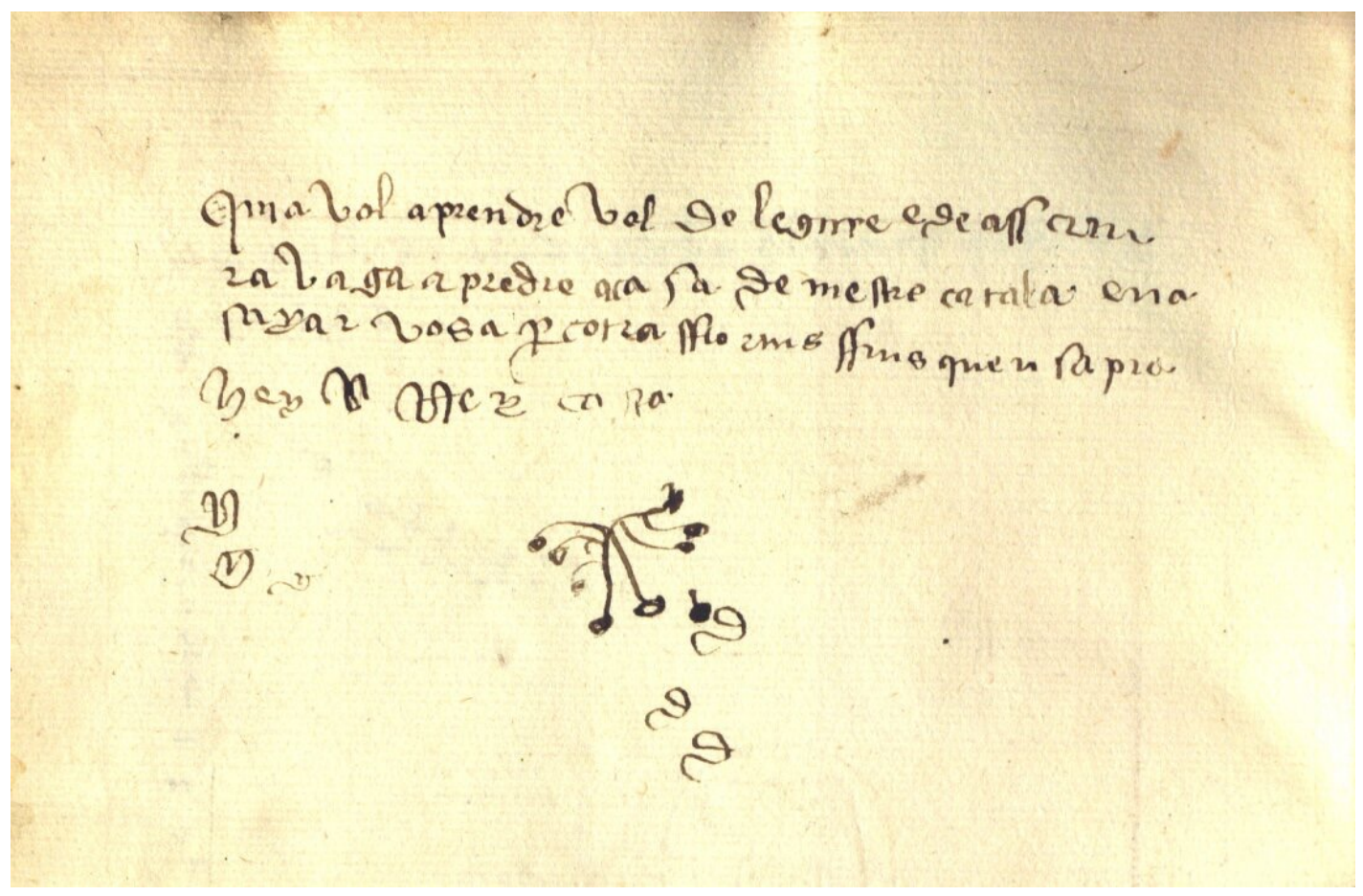

Fig 3: Anotació sobre l’aprenentatge de l'escriptura, de mitjan segle Xv (@ ACB, Còdexs, I2, f. [266]v).

La sola existència d'aquest còdex i la informació implícita i explícita que conté són ben bé extraordinàries, si s'interpreten en el context sociocultural que ofereix aquest article. Ramon Miquel i Planas, interessat abans que res per produir una bona edició de la primera de les obres que conté, va considerar que és un manuscrit inútil per a aquest propòsit i va denunciar la infidelitat del "copista" al text, que altera sense que hi trobés explicació, i l'escriptura fonètica que usa, en la qual, però, va veure un cert interès per a un estudi lingüístic (Miquel I9I6: XXI):

Manuscrit incorrectíssim, que fa ben poca honor a la fidelitat del copista. Aquest parafraseja lliurement el seu original, alterant d'una manera inexplicable el text d'en Conesa, que resulta a cada moment ininteligible. Ademés d'això, en Miquel usa una, diguem-ne ortografia fonètica, tan arbitrària, que arriba a desconcertar al llegidor. Potsér per això fóra interessant l'estudi d'aquest còdex, per retrobar-se en ell, ja en la primera meitat del segle xv, les característiques de la pronunciació barcelonina actual.

Aquestes consideracions han estat repetides més o menys íntegrament per investigadors que han escrit en moments més recents, que hi han vist sobretot -únicament- un interès lingüístic (Martínez I995: I, 78; Perujo 2000: I474; Cinotti-Codonyer 2003: I59). Curt J. Wittlin (I995: I83-87, amb molts exemples classificats), assumint la sentència dictada per Miquel i Planas, va estudiar les grafies del manuscrit, que ell anomena "no tradicionals" i fins i tot "cacografies", però va arribar a la conclusió que evidencien uns fenòmens que van més enllà de la simple transposició fonètica.

Aquests fenòmens gràfics, en realitat, són indicadors de gran interès per a l'estudi dels nivells d'aprenentatge de l'escriptura. En part, no s'allunyen dels que es poden trobar en altres textos produïts a l'àmbit domèstic, com ara les receptes i els receptaris mèdics. De fet, el candeler va produir una còpia destinada potser a l'ostentació - amb unes característiques formals que havien de produir l'efecte esperat: l'admiració de la seva persona pels interessos culturals que demostrava- 
però circumscrita a aquest àmbit domèstic, i no orientada a la difusió. No és en absolut, per tant, un 'copista' en el sentit professional del terme.

L'estudi de Wittlin sobre aquest manuscrit exemplifica l'estat de la qüestió sobre la cultura (literària) dels menestrals als anys 1990 ${ }^{35}$ La iniciativa del candeler sorprenia, per considerar-la impròpia del sector social que representava i, per tant, només podia tenir una explicació purament pràctica, utilitària, en cap cas relacionable amb el "gust per la literatura". Per això, les "alteracions" del text original de la traducció de les Històries troianes, que Miquel i Planas havia intuït que tenien una significació especial (“parafraseja lliurement el seu original”), no podien procedir de l'interès i la dedicació del candeler. Tanmateix, fa la impressió que aquests "afegitons" (Wittlin 1995: I88-I9O, amb nombrosos exemples) són molt més que això: són glosses explicatives a l'obra, potser sí elaborades per un lector-comentador anterior -però per què no un altre menestral?-, que han estat incorporades al text. Un fet que no sembla d'un interès menor (Perujo 2000: I474; Perujo 20I5: 79, I27), sinó que connecta amb els exemples dantescos que es ressenyaran més endavant.

La importància del manuscrit autògraf del candeler Miquel va més enllà encara. Aquest manuscrit és l'únic de la tradició catalana conservada de les Històries troianes en el qual apareix el nom del comitent al pròleg del traductor, el secretari i protonotari del rei Pere III el Cerimoniós Jaume Conesa, que inicià la tasca el I367 (Miquel I9I6: 3-4): "A instànçia e a pregàries de mosèn Pere Sescomes...”. En els altres manuscrits conservats que contenen el pròleg-tres de deu-és només "un noble hom e de gran compte" anònim, aparentment de fora dels cercles de la cort, "qui dezigave de aver less Istòries troyanes an romans, qui són an latí, per so com avia hoït dir que eren fort beles e que pertanyen a saber a tot cavaler" i, en canvi, no entenia prou bé el llatí com per gaudir-ne i obtenir-ne aquest profit sociocultural: "jasecia él antenés caucom del latí, anperhò (...) deya que no les podie antendra, per què no·n podia aver aquell pler ne l'antansió que ·s pertanyia”. Ni Miquel i Planas ni els investigadors posteriors que han estudiat aquesta traducció no han pogut identificar aquest personatge. La veritat és que tant el tractament nobiliari de 'mossèn' com l'al·lusió al poc coneixement del llatí que tenia fa que siguin impossibles els candidats d'estament inferior i els eclesiàstics i altres individus llatinistes que, ja amb poca fe, va recollir el primer (Miquel I9I6: XXIXXII, XXVII-XXIX) i també els que proposa Perujo (20I5: 77, 80-84). Miquel i Planas va desmentir, amb bon criteri, els que havien volgut atribuir la iniciativa al rei Pere III el Cerimoniós, però va acabar arribant a la conclusió que aquell nom havia de ser un error més del candeler, una idea que és desmentida per la reiteració que n'hi ha al pròleg de Conesa i, sobretot, per l'inventari de la vídua d'un jurista de Vic de I474, que reprodueix el mateix passatge amb el mateix nom..$^{36}$

El cas és que hi ha dades que donen la raó al manuscrit del candeler. Perujo (2OI5: 8I-84) ha explorat la família del bisbe de Lleida i després arquebisbe de Tarragona Arnau Sescomes (mort el I346), que havia nascut a Puig-reig (Berguedà) i posseïa el castell de Saidí (Baix Cinca), i que el I334 va fer bastir una capella funerària familiar a la catedral de Lleida. Era una família de propietaris

35. Wittlin I995: I82-83. Actualment se sap que el manuscrit no conté només els proemis de l'obra de Sèneca sinó, per aquest ordre, “els pròlegs de les deu tragèdies de Sèneca, la Medea (amb l'afegitó de Boccaccio) i Troades completes, i l'Agamemnon fins al punt on acaben” dos dels altres testimonis (Martínez 1995: I, 77). Les Històries troianes ocupen I77 folis i el volum sencer en té 264 , cosa que el fa excedir força del que es podria interpretar com a material de pràctiques d'escriptura (la lletra, molt formada, també ho descartaria).

36. "Primo, .I. libre scrit en paper ab posts cubertes de cuyro blanch ab .V. bolletes, apellat $Y_{\text {stòries troyanes, en }}$ romans. Comensa: 'A instància e pregàries de mossèn Pere Sescomes’; e fina: ‘e lo rey Abtomerso'. Lo qual la dita dona aportà en dot extimat al dit quòndam son marit” (Junyent I943: núm. 207; també a Cingolani I99O-9I: Io3, i Perujo 20I5: 79, 94). Aquest i els núm. I39 i I83 de la llista publicada per Junyent formaven part del dot de la vídua del jurista Pere Joan Desvall. D’altra banda, Perujo (20I5: 98-99) posa en dubte, al meu entendre sense necessitat, que l'obra posseïda pel balancer Guillem Garriga (vegeu la taula) sigui aquesta. 
rurals del Berguedà -la casa de Sescomes o les Comes és encara una masia de Puig-reig, situada sota el castell- que, sense abandonar aquest vincle, des de finals del segle XIII es va integrar al patriciat urbà de Lleida, on el llinatge va trobar la promoció mercès a la fulgurant carrera eclesiàstica d'alguns dels seus membres i a l'adquisició de dominis feudals, fins que, almenys algun d'ells, aconseguí el privilegi nobiliari (vegeu quadre genealògic adjunt). ${ }^{37}$ Tanmateix, els individus pròxims al prelat esmentat adduïts per Perujo, entre els quals és freqüent el prenom Pere, tot i ser senyors d'alguns llocs, no sembla que fossin nobles, i pertanyien a generacions anteriors a la que interessa. En canvi, en la forquilla temporal adequada es documenten dos nobles anomenats Pere Sescomes, un dels quals era cavaller i l'altre, aparentment d'una generació posterior, donzell. El tractament de 'mossèn' que es dona al comitent al manuscrit del candeler i a l'inventari esmentats descarta aquest darrer -al quadre adjunt, Pere Sescomes (IV) ${ }^{38}$-perquè, encara que al segle XV es pot trobar aplicat a donzells i també a eclesiàstics, en origen es reservava als nobles que havien estat adobats a cavaller. L'ús d'aquest tractament, que informava del rang de la persona en la jerarquia nobiliària, era molt estricte en els documents oficials i cal assumir que l'emprava amb el mateix rigor, en tot el que pogués escriure, un secretari i protonotari del rei -del rei Cerimoniós- en el segle XIV.

El cavaller Pere Sescomes (V) era fill d'Arnau Sescomes (II), senyor de la casa de Sescomes, el casal familiar al Berguedà, llavors a la vegueria de Bages. El seu pare, que no sembla haver estat cavaller, molt probablement era el nebot de l'arquebisbe Sescomes que s'esmenta a la liquidació dels seus béns (“Arnaldo de Cumbis, nepoti suo”, a Rius I930: 249). Aquest Pere Sescomes (V) és el "cavaller Pere Sescomes, domiciliat al Bages", que Jaume Riera (2003) va identificar com el comitent de Conesa. La font d'aquesta informació (comunicació oral de Jaume Riera) és un capbreu dels béns feudals que posseïa al Berguedà (rendes al terme del castell de Puig-reig, casa del Bosc) mossèn Pere Sescomes, cavaller, fill d'Arnau Sescomes, senyor de la casa de Sescomes, fet en l'any I365, que actualment és el manuscrit 28I de la Biblioteca de Catalunya. A la part del manuscrit que correspon a aquesta datació (vegeu fig. 4 i 5 ) consta que

Açò és capbreu lo qual mosè[n] En Pere Cescomes, cavaler, féu trasladar bé e felment del capbreu autèntich que l'onrat N’Arnau C.escomes, pare seu e se[n]yor de la casa de Çescomes, féu fer en forma pública, e açò són sumes feytes d’aquel axí com seguex (f. 3r) (...) Aquest cabbreu és traslat de les cartes antigues treyt, lo qual l'onrat En Pere Guiem del Bosch, cavaler e senyor de la casa del Bosch, de la vegueria de Berga, ne fou trer feelment e metre per capítols totes les rendes que-ls hòmens seus ne altres qualsquequals li fessen dins Berguedà, e fo feyt en l'an de .M.Cc. E com mossè[n] En Pere Çescomes, cavaler, fo senyor de la dita casa, féu-lo trasladar letra a letra, axí com seguex, en l'an de .M.CCC.LXV., .XIIII. kalendas de gener (f. I5r).

37. Segueixo l'elaborat resum sobre aquestes generacions de la família Sescomes fet per Joan M. Perujo (2015: 77-84) a partir de Rius I930, Tarragona 1979, Serra I982 i Bosch 200I, amb algunes esmenes i noves dades.

38. Era fill del cavaller Ramon Sescomes (I) (Mañé-Rovira 2005-I3: III, doc. 855 i 929). Heretà la senyoria de Saidí (Baix Cinca), potser per manca de descendència de Joan Sescomes àlies de Berriac, i que va retenir fins que el I4O4 Martí l'Humà el va forçar a vendre-la (Salleras 2006: 68-69 i doc. 22). Es va casar (c. I368) amb Elionor de Tous, senyora de Concabella, pubilla d'aquest llinatge de la baixa noblesa de l'Anoia que, al servei de la corona, va tenir una notable ascensió durant els regnats de Pere el Cerimoniós i Joan I (Roca 2OII). Encara donzell, va participar a les corts de Perpinyà, Sant Cugat i Barcelona de I4O5-Io (sessions de Barcelona de I408, a Cortes r896-г922: V, 229, 454, 465, 47 I; VI, 2O, 38, 5I, 53, 57, 6I, 64, 78, 93), i va ser el primer Sescomes laic a fer-ho. El matrimoni és esmentat a la primera crònica de Sant Jeroni de la Murtra, ell amb el tractament de 'mossèn', que no és significatiu per ser una obra de principis del segle XVII (Díaz Martí 2006: I56, pàssim). 


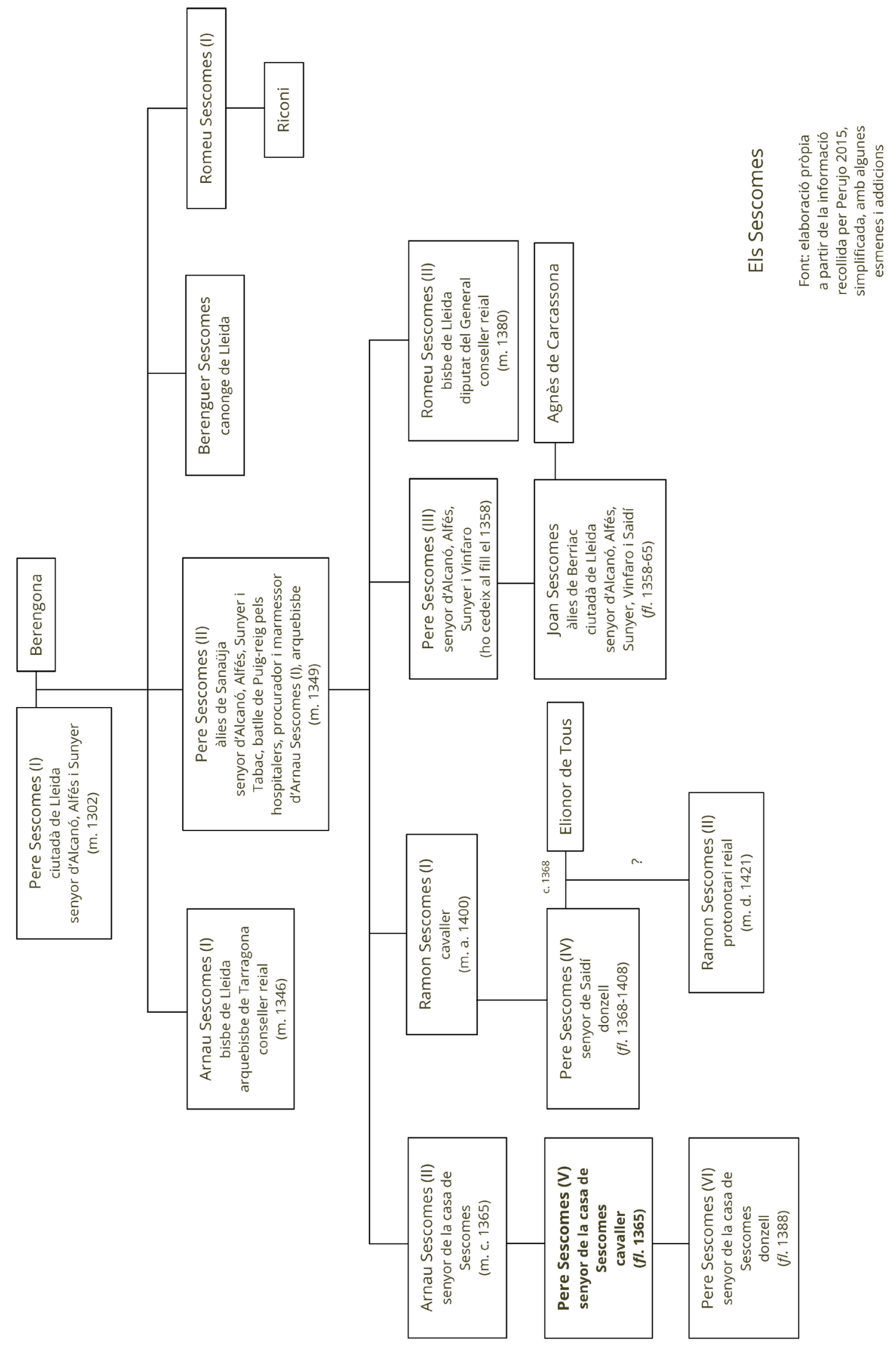


La part original del capbreu, escrita en lletra gòtica textual, té addicions clarament posteriors, en lletra semicursiva i cursiva, sobre els béns feudals a la Segarra (Suau, Tapioles, quadra de l'Escura, Solermonegal) d'un altre Pere Sescomes, que era donzell, efectuades des d'abans de 1385 :

A .XXIIII. de mayg l'any de .M.CCC.LXXXVIII. lo honrat En Pere Çescomes, donzell, féu ordenar e posar en los seus lochs de Suau e de Tapioles e quadre de la Escura, alous seus, los bans següents (f. rv) (...) Aquest és lo capbreu de Tapioles e de Suau, de la quadra de l'Escura e de Solermonegal, lo qual s'és trasladat d'un altre capbreu antich bé e feelment, mot a mot, segons que en lo dit capbreu se contenia (f. 2Ir, amb actualitzacions de censos d'una mà cursiva de I385, I388 i I39I) (...) Memorial e translat del cens de Solermonegal (f. 34r, amb una actualització de I385) (...) Aquest és lo cens e les parts que l'hereu del mas de Suau prenia e ara ho pren En Pere Çescomes, senyor de Tapioles e de Suau (f. 35 v).

En el repàs que fa del llinatge Sescomes, Perujo (2015: 83-84) cita aquest manuscrit i n'edita la primera rúbrica, però identifica l'Arnau Sescomes que s'hi esmenta amb l'arquebisbe homònim i no el relaciona amb el cavaller esmentat per Riera (Perujo 20I5: 80). Aquí s'han transcrit algunes rúbriques del manuscrit per fer notar l'aplicació rigorosa del tractament diferenciat que s'hi fa al cavaller ('mossèn') i al donzell, que d'altra banda no avala aquesta identificació.

Ara per ara no sembla haver-hi cap candidat millor -per llinatge, per cronologia i per rang nobilari- per identificar el mossèn Pere Sescomes que, segons la còpia del candeler Bartomeu Miquel (I433) i l’inventari del jurista de Vic (I474), hauria estat el comitent de la traducció de Jaume Conesa de les Històries troianes ( ${ }_{3} 67$ ). Tanmateix, no en consta cap relació amb Conesa ni amb la cort reial, la qual cosa no vol dir que no hagués existit. Sí que hi era, però, aquesta relació amb un parent coetani del cavaller Sescomes, el canonge de Barcelona i després bisbe de Lleida Romeu Sescomes (m. I380), que va ser conseller de Pere el Cerimoniós (Perujo 20I5: 8o-8I).

No s'ha trobat cap explicació satisfactòria a l'absència del nom del cavaller, convertit simplement en "un noble hom e de gran compte" anònim, als altres tres manuscrits de l'obra que en conserven el pròleg, tots datables en el segle XV, ${ }^{39}$ dels deu testimonis que se n'han localitzat (CinottiCodonyer 20O3; Perujo 2OI5: I23-48), i que també es detecta a l'inventari dels béns d'un mercader de Cervera de I429 (Llobet 1997: 408; Perujo 20I5: 9I-92). Miquel i Planas va determinar que havia de ser un error del candeler. Perujo (20I5: 84), a partir de la rúbrica del capbreu, proposa que aquest cavaller podia ser un fill natural de l'arquebisbe Arnau Sescomes i que, per això, algú va decidir ocultar-ne el nom, però també suggereix que "un copista o algun posseïdor d'un dels manuscrits" podia haver introduït el nom del cavaller per raons desconegudes.

39. El ms. que ara és al monestir de La Vid (Burgos), del segle XIV, té els primers folis suplerts en el segle XV, quan va pertànyer als Montcada (Miquel I9I7: XXVI). 
age rg cap bum loqual mole eni 1) cetomnes camalet fin tralla

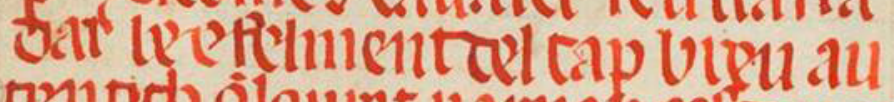

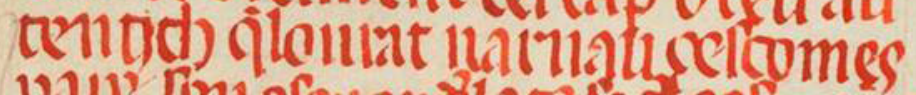
wate rem clevor diagit d celoms

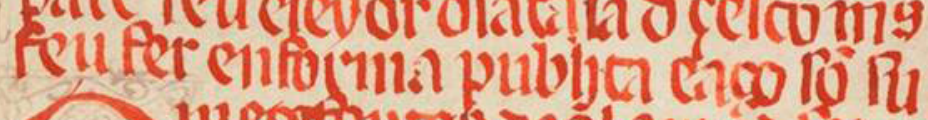
- 1 megtevtes dañlay co minues mer a proners te $1 \cdot$ tios atcur ci plan onmenas fe

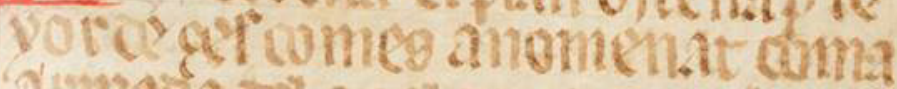
d'matua cil qual aoc cone alont fe - vor miacturs elplets ift aptens

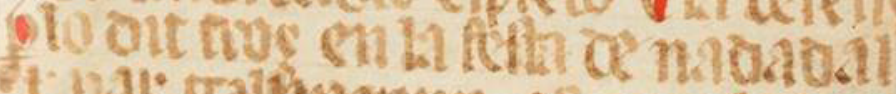

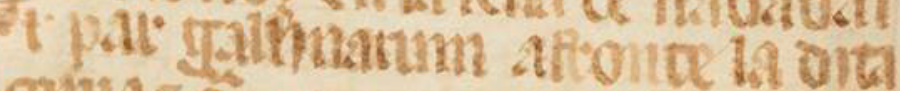
conta $8 \mathbb{1}^{\circ}$

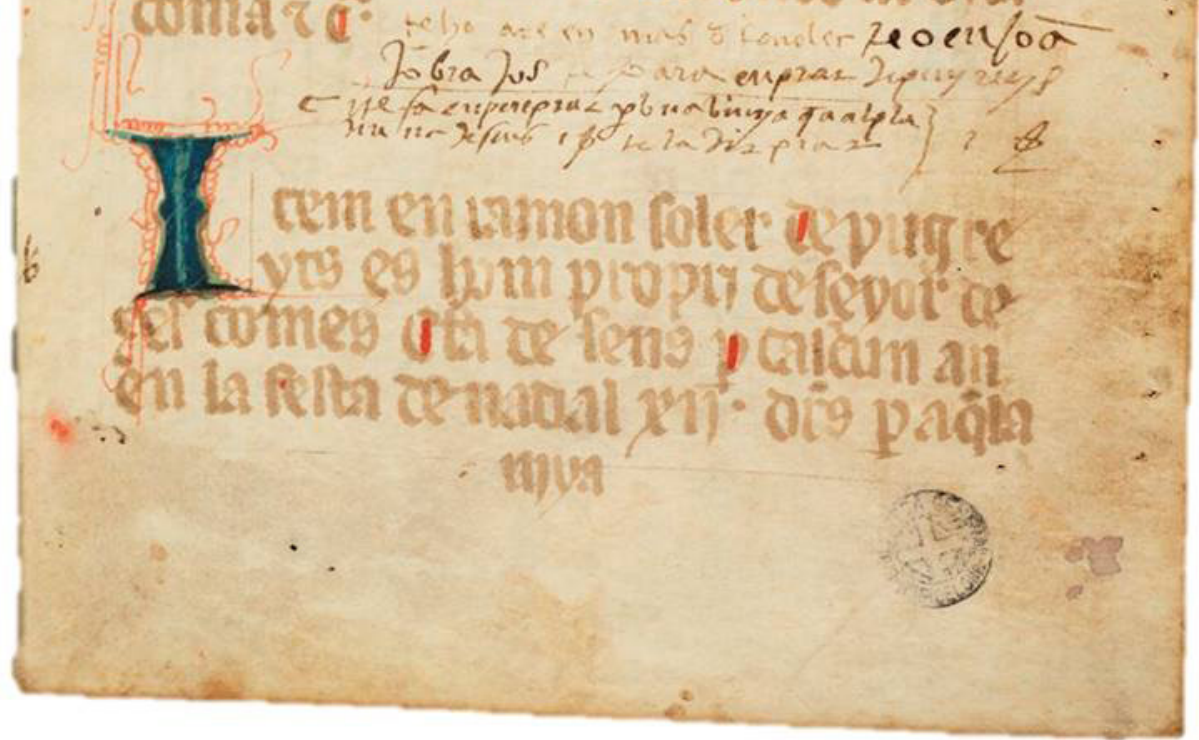

FiG 4:Capbreu de les rendes de mossèn Pere Sescomes, cavaller, senyor de la casa de Sescomes, a la sotsvegueria de Berguedà de la vegueria de Bages o Manresa, I365 (C) BC, ms. 28I, f. 3 r). 


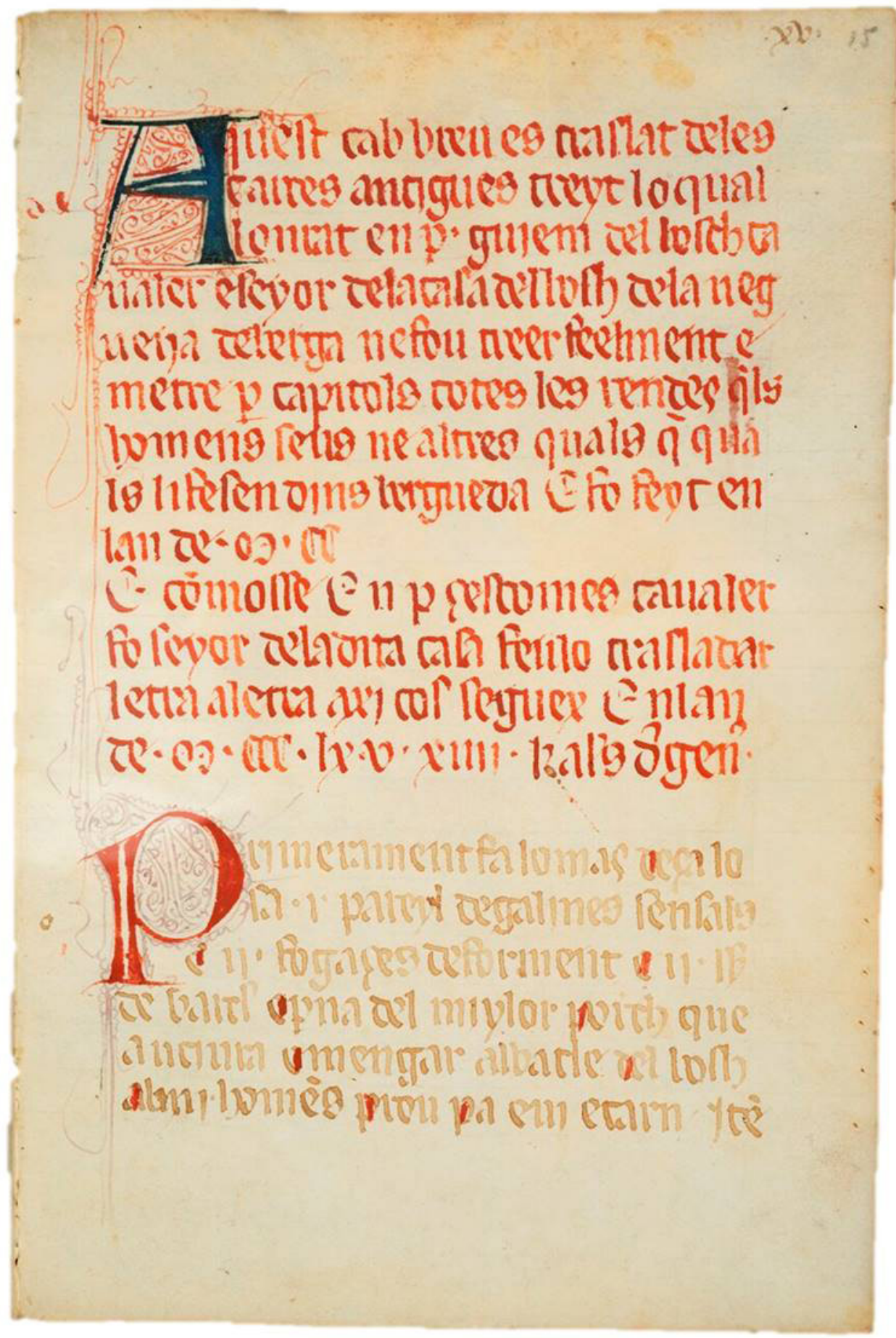

Fig. 5: Capbreu de les rendes de mossèn Pere Sescomes, cavaller, senyor de la casa de Sescomes, a la sotsvegueria de Berguedà de la vegueria de Bages o Manresa, I365 (@ BC, ms. 28I, f. I5r).

Mentre no es trobi un lligam entre Jaume Conesa i el cavaller Pere Sescomes la qüestió, certament, queda oberta. Però és possible proposar una explicació més convincent. La desaparició del nom del cavaller podria deure's al fet de ser un noble desconegut als ambients cortesans, que en 
vivia allunyat i que, tot i tenir el rang de cavaller, tenia un patrimoni limitat. ${ }^{\circ}$ Pere Sescomes era un membre de la baixa noblesa, un grup social menystingut per l'elit nobiliària. No és impossible que la traducció se suscités en aquests cercles de la baixa noblesa, poc o gens integrats a la cort. Un sector de la noblesa ben necessitat de la legitimació que aquesta literatura cavalleresca podia proporcionarli ("l'antansió que·s pertanyia"), més encara si el llinatge tenia arrels a l'estament inferior, com era el cas dels Sescomes. En definitiva, eren unes necessitats de promoció que no s’allunyaven tant de les que sentia el candeler, i la menestralia benestant en general.

Per això, no és estrany que al mateix dret feudal es teoritzés la necessitat d'aquesta literatura cavalleresca per al noble. En efecte, entre les coses que els nobles havien de tenir als castells, segons el més important dels comentaris als Usatges de Barcelona que actualitzaven el dret feudal a la llum d'una societat creixentment urbana (Jaume Marquilles, Commentaria super Usaticis Barchinone, I448), calia comptar:

Item, sint ibi romancia et libri gestorum, videlicet Alexandri, Karoli et Rollandi et Oliverii et de Verduno, de Ancellino lo Daucer [sic per Aucellino lo Danter, Antelme Danter] et de Ocovel [sic per Ospinel?] et de Bechon [sic per Bethon, Daurel e Beton] et de comes de Mancull [sic per Natuil, Nanteuil] et librorum magnorum et nobilium bellorum et preliorum que facta sunt in Yspania. Et de hiis animabuntur et delectabuntur. ${ }^{4}$

\subsection{El blanquer Bernat Nicolau i la Comèdia de Dante}

Tot i que Dante no apareix a la taula que acompanya aquestes pàgines, també va ser un autor llegit i valorat pels menestrals. Francesc Gómez (2OI4: 4I-43; revisat a Gómez 2OI6: I79-8I) recull una informació molt interessant sobre el tema i pensa que individus de procedència italiana que vivien o viatjaven als Països Catalans devien contribuir "a la difusió de la Commedia entre les classes urbanes”. Entre aquests italians, esmenta el cas de mercaders que citaven Dante a la correspondència, però també el de Joan de Pisa, un argenter instal-lat a Barcelona -amb el mateix rei entre els seus clients. Aquest argenter, a mitjan segle XV, s'oferia com a lector de les obres del poeta i se'l disputaven el comte de Prades, per a la formació del seu fill ("legir lo Dant al fill del molt egregi comte de Prades e altres bons ensenyaments"), i uns formenters barcelonins, per a la d'ells mateixos ("e axí mateix que, [ell] mostrant-vos lo Dant e altres coses, li faríeu companya de fills").

40. Perujo (20I5: 79) avança, abans d’arribar a la conclusió esmentada, que, possiblement, “el nom de Pere Sescomes no era gaire conegut dels copistes posteriors i va ser eliminat”. Quant a la posició de la família, del castell de Puig-Reig, que era de l'orde de l'Hospital (Cortes r896-ı922: II, 93, any I359; IV, I44, any r378), els Sescomes només n'administraven les rendes com a batlles, no n'eren senyors com s'ha malentès. Deixant de banda els dos prelats de la família (els esmentats Arnau i Romeu Sescomes), no consta que els membres laics del llinatge tinguessin cap paper en l'alta administració reial i, com s'ha vist arran del donzell Pere Sescomes, no foren convocats a corts fins I 408. És possible que Ramon Sescomes, protonotari dels reis Martí, Maria de Luna i Ferran I, fos membre de la família, però no s'ha provat. Potser va ser el "secretario Sescomes" al qual al-ludeix, com a antic posseïdor, una nota del segle XviI del manuscrit I523 de la Biblioteca Nacional (Madrid), del tombant del segle XIV al XV, que, malauradament, és un dels que no conserva el pròleg de Conesa.

4I. AHCB, Consell de la Ciutat, Manuscrits municipals, oI/IG-I8, f. 378vb, passatge citat per Alòs I9IO: I3I, en nota, a partir de l'edició impresa a Barcelona el I505, f. 378vb, un i altra amb lliçons pràcticament idèntiques, que he verificat. Al castell de Tous, de la família del mateix nom emparentada amb el donzell Pere Sescomes (IV), hi havia, en els anys I372-I4IO (Alòs I9IO: I32-53), diverses obres cavalleresques en vulgar (Llibre de l'orde de cavalleria, Història d’Alexandre, Tristany, Destrucció de la Taula rodona). 
Al final, aquests darrers, per desavinences en la retribució, li van segrestar els llibres ("los libres ab los quals vos puga legir”), acció gràcies a la qual el cas ha transcendit. ${ }^{2}{ }^{2}$ A més de l'interès evident pel famós poeta italià, que no sembla només literari sinó també d’un caire sociocultural més ampli, per l'estatus que proporcionava i pel fet d'entendre la seva obra com una summa del saber (Gilson 2OOI), fa la impressió que la lectura dels seus llibres podia servir també per a l'aprenentatge del toscà o italià, ${ }^{43}$ llengua útil per a la gestió dels interessos mercantils i els de l'estament nobiliari, tant al país, on la presència de mercaders toscans està ben documentada, com a Itàlia, terra atractiva per al comerç i per a l'expansió feudal catalans. En qualsevol cas, les expressions emprades al document suggereixen que Dante era especialment valorat, que se n'estudiaven diverses obres -obres i comentaris, segurament-i que l'aprenentatge que s'hi cercava era polifacètic.

És més important encara per a aquest treball, perquè fa referència a un menestral català, el cas del blanquer de Barcelona Bernat Nicolau, un dels dirigents del seu gremi, implicat al govern municipal i comitent d'obres artístiques. El I46o, aquest menestral copià un manuscrit en italià de la Commedia de Dante acompanyada de glosses explicatives en català i en italià. Com en el cas dels “copistes extravagants” (Martí 202I) esmentats abans, Nicolau no va deixar de fer constar la seva intervenció:

Ffo acabat lo present Purghatorie segona Comèdia de Dant per mà d'En Bernat Nicholau, blanquer, digous a .X. de juliol, any mil .CCCC.LX.

[En transcripció diplomàtica:] ffo acabat lo prefent purghatori e fegona comedia $\mid$ de dant per ma den bernat nicholau blanquer digous $\mid \mathrm{a} \cdot \mathrm{X} \cdot \mathrm{de}$ juliol any Mil $\cdot$ CCCCLX $\cdot 44$

Bernat Nicolau era fill de Bertran Nicolau, un ric mercader penedesenc instal-lat a Barcelona que va impulsar o fundar monestirs i hospitals a la ciutat i al seu entorn, i que morí el I42I (Díaz 2005). En el llarg conflicte que els menestrals van mantenir per aconseguir participar al govern municipal va ser, lògicament, buscaire, i va formar part de la nòmina dels elegibles a partir de I445 (Batlle i973: 595, 6o8). El I $45^{8}$ se'l documenta formant part del Trentenari o comissió permanent del Consell de Cent, i el I459 encara va formar part d'una altra comissió municipal (MNA: II, 322), sempre entre els representants dels menestrals.

Com a prohom del gremi dels blanquers, el seu nom consta al contracte signat per aquest amb Jaume Huguet l'any I 463 perquè pintés el monumental retaule que havia de presidir el convent de sant Agustí de Barcelona -l'anomenat retaule de sant Agustí o dels blanquers, parcialment conservat al MNAC- concebut perquè exhibís la potència del més acabalat dels gremis del ram del

42. AHPB, 2O4/2, bossa, s/n, 26/O4/I 458. És un requeriment notarial de l'argenter Joan de Pisa publicat per Soler (I92I: I54-55) i, més recentment, revisat per Gómez (20I6: I8O-8I), que aporta bibliografia sobre el personatge. En un altre document annex hi ha la resposta dels formenters, només publicada per Soler I92г: $555^{-56}$, que se centra en els compromisos econòmics contrets sense esmentar Dante. Un formenter era un mercader que traficava amb forment 0 blat, especialment amb el millor.

43. Aquesta possibilitat és apuntada per Gómez 20ı6: i69 en comentar un altre cas. Compareu amb el que s’ha dit abans sobre l'ús que es feia del Llibre dels àngels d'Eiximenis per a l'aprenentatge de la lectura. Per a la funció pedagògica i política de l’obra de Dante a Florència durant el segle XV, vegeu Bec (I984: IO2-o9), i per a Sicília, Bresc (I971: 56).

44. HSA, ms. HC 397/688, f. 74v, transcrit del manuscrit, que conté el Purgatorio. El colofó, escrit en tinta vermella, ha estat publicat per Bohigas ı96ı: 252 i Gómez 20ı6: ı87 (vegeu fig. 2.4). Bohigas (I96I) descriu el ms. i en reprodueix els ff. ı8r i 2Iv. Gómez 20I6: ı87-88 aporta les pinzellades principals del perfil biogràfic de Nicolau, que es completa aquí amb altres fonts. 
cuir i un dels més puixants de la menestralia de la ciutat. ${ }^{45}$ A més, tant pot ser el seu pare com ell mateix el comitent representat de genolls davant la Mare de Déu al retaule del monestir de Domus Dei de Miralles (Castellví de Rosanes, Baix Llobregat), fundat pel seu pare, que es va pintar vers I 46I-62 i on consten les inicials $B N$ corresponents al promotor (també al MNAC; vegeu fig. 6). Tot i que no s'hagi pogut documentar, els 40 anys que separen la mort del pare de l'elaboració de la peça conviden a ser cauts a l'hora de descartar que ell hi hagués pogut intervenir, més encara tenint en compte que sembla un personatge perfectament conscient que la promoció de l'art, igual com la tria dels seus llibres, tenien una valuosa funció social. ${ }^{4}$

La iniciativa de Bernat Nicolau amb la Commedia no sempre li ha estat reconeguda. És molt significatiu per a aquest estudi que tota la bibliografia publicada fins als anys i99o interpreti el nom que apareix al colofó com "Bernat Nicholau Blanquer": blanquer no podia ser l'ofici del personatge sinó que n'havia de ser el cognom, perquè era inconcebible que un menestral pogués tenir interessos d'aquesta mena i menys encara amb Dante. Tal com recull Gómez (20I6: I87), van ser els historiadors de l'art que van desfer aquesta confusió (Ainaud 1993: 52), però fa l'efecte que no l'havia causat, com argumenta, l'“ambigüitat del colofó”, sinó més aviat el simple prejudici sobre la nul.la familiaritat dels menestrals amb l'escriptura i el llibre, els seus interessos culturals i, no cal dir, el consum de literatura. Ainaud va advertir, en efecte, que "els blanquers eren un dels sectors més poderosos de l'economia barcelonina, i que de fet els podem situar entre els industrials més que entre l'artesanat”. Si un menestral com Nicolau demostrava tenir la "destacada categoria intel-lectual” que indicaven els contractes artístics i el gust per Dant, havia de ser perquè formava part de l'elit.

És difícil saber si Bernat Nicolau havia aconseguit formar part de l'elit social barcelonina, però sí que es pot endevinar que aquest era el seu objectiu, igual com havia estat el del seu pare, que molts veuen només com un altruista fundador d'hospitals i convents. I s'endevina també que el compartir gustos artístics i literaris amb l'elit, i el demostrar que s'és capaç d'invertir diners i energies en el mateix tipus d'iniciatives, era més una palanca per aconseguir aquell objectiu que no pas la manifestació de l'èxit. ${ }^{47}$ La potència econòmica dels blanquers, certament superior a la d'altres gremis -però sense perdre de vista que això s'ha d'entendre en el marc dels gremis de la ciutat- és el que genera unes necessitats de promoció sensiblement superiors a les d'altres oficis, que prenen cos en un joc d'ostentació i de preteses complicitats culturals que ens ha pervingut calidoscòpicament. Per això les iniciatives que es coneixen del blanquer no tan sols són més complexes que les del patró i el candeler, sinó que el domini de l'escriptura i de la llengua escrita que s'ha esforçat per adquirir també és ben superior.

45. Vegeu Ainaud r993 i Gómez 20ı6: I88, més la bibliografia que citen, entre d’altres publicacions. El primer subratlla que durant els anys de la guerra civil catalana, amb els encàrrecs dels estaments superiors molt minvats, Huguet va contractar nombrosos retaules amb les confraries dels menestrals, però que, per valorar correctament el fenomen, també cal tenir en compte la personalitat i el gust dels individus que intervenen als contractes.

46. Vegeu Ruiz 2003, que tot i atribuir l'encàrrec a Bertran Nicolau pare admet que no es pot descartar la possible iniciativa o intervenció del fill blanquer, tal com ha defensat part de la bibliografia anterior, que cita. El I459 els consellers de Barcelona “anaren visitar la casa appellade Casa de Déu, fundada per En Bertran Nicholau, quòndam, mercader” (MNA: II, 3I5), molt possiblement a instància del ben situat blanquer. Vegeu també la nota anterior.

47. Gómez 2016 segueix l'argument d'Ainaud i proposa la conclusió inversa. 


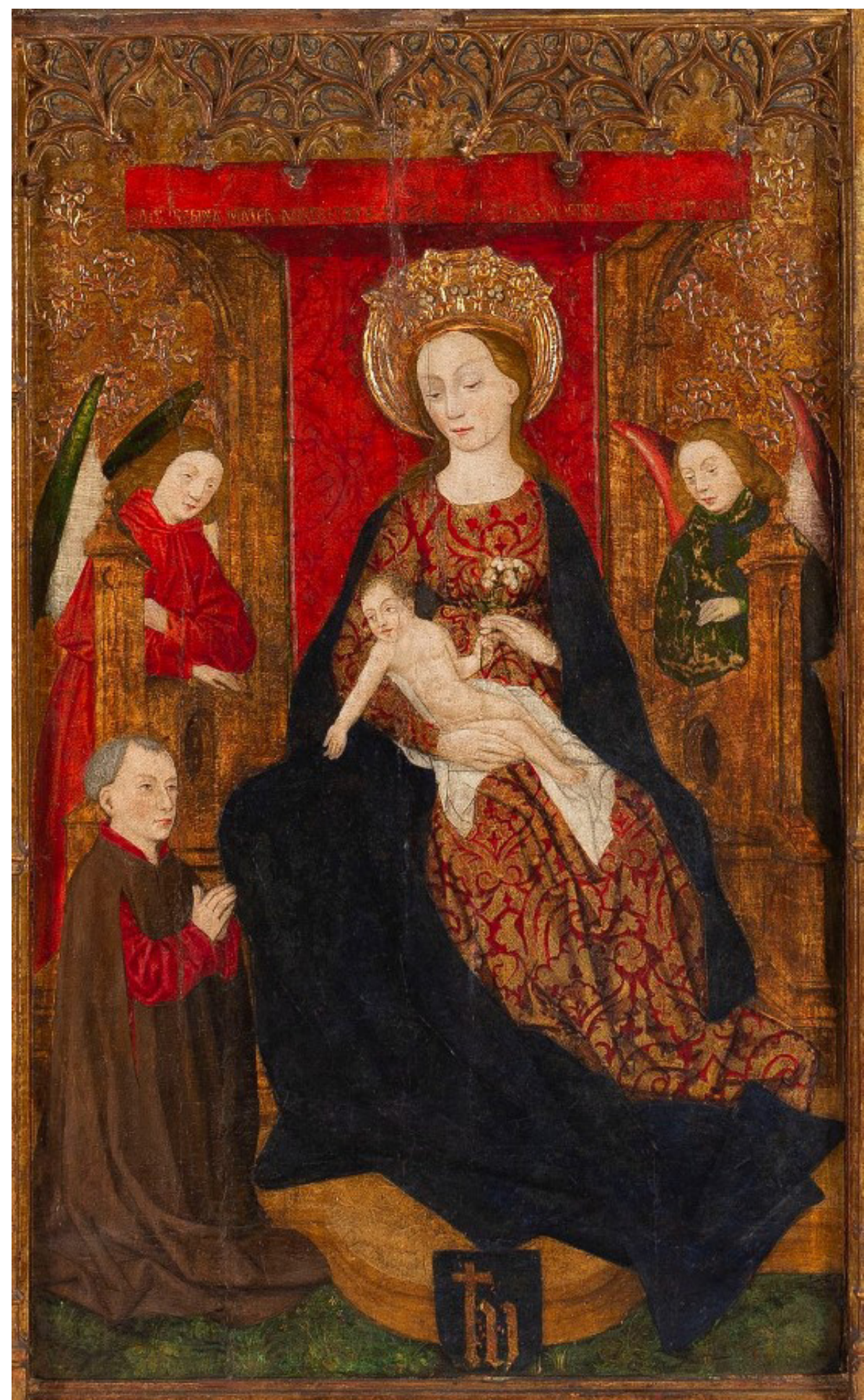

Fig. 6: Antoine de Lonhy, Retaule de la Mare de Déu, sant Agustí i sant Nicolau de Tolentino, c. I46I-62, procedent del monestir de Domus Dei de Miralles (Castellví de Rosanes, Baix Llobregat). Detall de la taula central, amb el promotor orant i les inicials $B N$ (@ MNAC Barcelona 2O2I, adquisició de la col-lecció Plandiura, I932). Vegeu l’obra sencera a $<$ https://tinyurl.com/4xkggc8f $>$.

Per a més intranquil-litat dels qui han volgut veure en Bernat Nicolau una excepció incòmoda, el manuscrit autògraf del blanquer no conté només la còpia del text italià de Dante, sinó també una gran quantitat de glosses explicatives en català i en italià afegides en uns generosos marges 
que ja havien estat concebuts per a aquest menester. Aquestes glosses, que Francesc Gómez està estudiant, van ser escrites primer en català i després, als espais encara disponibles, en un italià amb catalanismes, sens dubte de mà catalana (Bohigas I96r: 254, 26I-62; Gómez 20I6: I87). Bohigas va creure veure la mà del blanquer en una part d'aquestes glosses, però Gómez considera que són de mans diferents i així ho sembla, tot i que el fet de ser de filons escripturaris diferents del del text pot enganyar. En qualsevol cas, els autors d'aquestes glosses les van introduir al cap de poc d'haver-se escrit el text de l'obra. No és possible determinar quins individus van ser-ne els autors, però sembla lògic pensar en el cercle immediat del blanquer, qui sap si els seus fills, que haurien seguit els processos d'aprenentatge que aconsellava Eiximenis i que, quant a Dante, ens descobreix l'argenter Joan de Pisa. Unes glosses explicatives a una obra especialment valorada que, tot i ser molt més complexes, comparteixen la intenció -fer-se seva l'obra- amb les que es detecten als textos copiats pel patró Reixac i el candeler Miquel. Un desig de fer-se seva l'obra que és independent del fet que les glosses d'aquests darrers textos -i probablement també les del text copiat pel blanquerprovinguin dels seus antígrafs, les circumstàncies dels quals desconeixem.

En efecte, aquests testimonis conservats no permeten assegurar per quin canal els menestrals van obtenir les obres que desitjaven copiar. És molt possible que fos el del préstec, tal com intueix Gómez (20I6) quant al blanquer dantesc i ho dedueix Iglesias (I996a: 3I6-I7) arran del cas força explícit d'uns notaris barcelonins que intercanviaven un cançoner a mitjan segle XV. A la taula es recull el cas d'un moneder que el I440 va recuperar un exemplar en català de les Històries troianes que havia cedit en préstec a Galceran Carbó, un 'ciutadà' de l'oligarquia de Barcelona, ${ }^{4}$ i, tot i que no s’indiqui que el motiu del manlleu fos la còpia, sí que il-lustra sobre un altre fet: el préstec de llibres podia ser socialment multidireccional.

\section{Autors menestrals}

$\mathrm{E}$ ls menestrals no van ser únicament consumidors de literatura; també van tenir-hi un paper actiu, com a autors. És cert, però, que la quantitat d'autors menestrals és minsa, si bé l'activitat literària d'aquest col-lectiu està documentada des de l'època de plenitud de la poesia trobadoresca. Riquer (I975: I, 24) recull els casos dels trobadors Bernart Marti (mitjan s. XII), que era pintor (pictor), Guilhem Figueira (fl. c. I2I5-I25O), sastre i fill de sastre, i Joan Esteve (fl. I27O-I288), oller. També hi va haver trobadors professionals que eren fills de menestrals, com Peire Vidal, que ho era d'un pellisser, i que aconseguí promocionar-se a les corts dels comtes de Tolosa i dels reis catalans, principalment (Riquer I975: I, 2I).

\section{I El carder Bernat Serradell}

Entre els autors literaris menestrals que van escriure en català, el més conegut és Bernat Serradell. El seu Testament, escrit vers I422-I424, és una peça de narrativa en vers que, manuscrit i imprès, va tenir un gran èxit (vegeu-ne, a la taula, les atestacions que corresponen al tema d'aquest treball), i això malgrat que se n'ha conservat un sol manuscrit datat, sens dubte, en l'any I $45^{2}$. El seu editor

48. La devolució fou feta per Francesc, fill de Galceran, ja difunt (Madurell 1979-82: doc. I28). Tant Galceran Carbó com el seu fill Francesc pertanyien a l'estament mercantil i foren consellers de Barcelona. Galceran tenia altres llibres literaris en préstec: un Dant en italià, que era del notari i escrivà del Consell de la ciutat Bernat d'Esplugues i que, a la mort d'aquest (I433), encara no havia retornat (Iglesias 200I: 70). 
(Pacheco 1971), que ha localitzat diversa documentació biogràfica de Bernat Serradell dels anys I395-I445, i la resta de la bibliografia han precisat que era un corder de Vic, fill d'un altre corder homònim de la mateixa ciutat. Del Testament, se n’ha valorat la qualitat literària (Pacheco I97I: 526o; Cabré-Espadaler 2OI3: 355-58), considerant-la l'obra d'un bon narrador dins les coordenades d'un estil popular, "planer, gairebé sempre directe, sovint familiar”. Un estil que, tanmateix, no sempre és estimat per una crítica que massa poques vegades hi ha sabut veure que "és l'estil d'una societat urbana i educada que sap trobar plaer en la forma d'expressió" (les frases destacades són de Pacheco 1971: 55-56).

Sense poder conèixer el context sociocultural que s'aporta aquí, la valoració de l'obra s'ha vist afectada per l'ofici menestral de l'autor. És ben significatiu que aquest ofici sempre hagi requerit explicacions especials, a causa de l'estranyesa que ha causat un escriptor d'aquest perfil, sovint magnificant-lo. Cal dir que Pacheco (I97I: II-I6), havent-ne pogut analitzar alguns documents, és realment mesurat a l'hora de valorar la posició socioeconòmica de Bernat Serradell, que situa en una petita burgesia puixant, enriquida per l'ofici, les operacions creditícies i l'acumulació de patrimoni. ${ }^{49}$ Un enriquiment que li va permetre fer realitat l'anhel de promoció, relacionant-se amb els sectors de l'elit social i cultural burgesa, compartint-ne les inquietuds i els gustos, i aconseguint l'ascens social en la pròxima generació, en casar la filla amb una de les principals famílies de Vic, de mercaders. Més que probablement, aquest esquema era més factible en una ciutat petita que no en una de gran i, malgrat tot, convé no perdre de vista que aquests menestrals, per rics que fossin i per ben relacionats que estiguessin, continuaven socialment encasellats al seu gremi, que no formava part del patriciat urbà. En canvi, en anàlisis més recents, que parteixen d'una lectura ràpida de Pacheco (I97I), es nega que Serradell i els seus paral-lels siguin el que entenem per "artesans o botiguers, com el nom dels oficis podria fer pensar, sinó més aviat el que avui se'n diria empresaris" i s'afegeix que "no es tracta d'un cercle de burgesos, en el sentit ampli que té avui el terme, sinó de patriciat urbà” (Cabré-Espadaler 2OI3: 358).

Aquestes explicacions s'han fet pivotar sobre un ofici, el de corder, que, en realitat, no és el que tenia Bernat Serradell. Als capítols matrimonials de I397, tal com foren publicats per Pacheco (I97I: I23-24), es llegeix “Bernardo Serradelli, carderio, civis vicensis”, i al testament real d'aquest individu, fet en l'any I445 (Pacheco I971: I25-27), "Bernardus Serradell, carderius, civis vicensis, filius Bernardi Serradelli, quondam, carderii vicensi” (vegeu fig. 7). L'ofici de Serradell, malinterpretat pel mateix Pacheco i per tota la bibliografia, és el de carder. Pot semblar que, per a la comprensió de la seva obra, no ve d'una lletra, però no és ben bé així. Si el de corder era un ofici menor, practicat sobretot a les localitats marineres $i$, segons com, mal vist pels usos penals i repressius que tenia la corda, el de carder tenia tot un altre rang, derivat del fet de ser un dels que integraven la indústria tèxtil, i això eren paraules majors. Els carders fabricaven les cardes, l'instrument amb el qual treballaven -cardaven - la llana els paraires per, després, poder-se teixir. Constituïen un gremi auxiliar del d'aquests darrers, que era un dels més importants del ram. És sent carder, i no corder, com s'entén l'enriquiment i les possibilitats de promoció -el dot de la filla que es va poder permetre- de Bernat Serradell i, per tant, també el cercle social i cultural que va tenir.

49. "Bernat Serradell no sembla ésser una figura brillant de la societat vigatana; almenys no l’hem sabut trobar entre els personatges que exercien càrrecs de govern o altres funcions importants a la capital de la Plana. Però va assolir una bona posició econòmica; degué pertànyer a aquella menestralia vigatana enriquida que posà el fonament d'una burgesia culta, il·lustrada amb noms com el del poeta Andreu Febrer i el del jurista Jaume Callís” (Pacheco I97I: II). 


\subsection{Poetes menestrals}

La poesia de certamen, per la seva naturalesa d'institució ciutadana, proporciona alguns exemples més de menestrals que tenien l'impuls d'escriure literatura. D'entre els certàmens poètics valencians, destaca el que es coneix com Trobes en lahors de la Verge Maria (I474), en el qual van participar dos menestrals, un argenter i un naiper o fabricant de naips (Ferrando I983: I68). L'argenter (“mestre Pere Civillar, argenter"), escriu en castellà i per això s’ha assumit que era d'aquesta procedència. Sobre el seu poema ("Al tempo que Febo su gran claridat"), s'ha dit que "la composició resulta poc imaginativa i ben pobra en recursos estètics”, per imitar amb poca traça un tema de la poesia de cancionero (Ferrando I983: 202, 238).

Si d'aquest autor no es tenen més dades, el cas del naiper és una mica diferent. Aquest naiper, Joan Santcliment ("Johan Sentcliment, nahiper"), de possible origen lleidatà (Ferrando I983: 20305), hi va aportar una cançó mariana (“Sancta dels sancts, pus sou vengud'al segle”, ed. Riquer I985: 386-87; i RIALC Raor6r.2; també ed. Ferrando I983: 302-04) “d’una certa originalitat estròfica", atès que, tot i compartir artificiositat amb les altres composicions que s’hi van presentar, habitual als certàmens, és una adaptació “d’una de les més famoses creacions de la lírica trobadoresca, la sextina d'Arnaut Daniel que comença 'Lo ferm voler”, amb mots-rima al final de cada vers que depenen del mateix Arnaut Daniel, de Jordi de Sant Jordi i del diccionari de la rima de Jaume Marc (Riquer I985: 385-89; vegeu també Ferrando I983: 238-40).

De Joan Santcliment, es conserva, al Cançoner del marquès de Barberà, un altre poema, un plany per la mort de dos personatges d'un alt valor documental, pels fets i individus que esmenta, escrit poc més tard que l'anterior, a finals del mateix any I474 (“Los fats cruels, per migà de Fortuna”, ed. Riquer i985: 389-9I; i RIALC Raoi6ı.I; també ed. a Ferrando I983: 205-O7; vegeu també Martí I997: 474, 477, 490). Un dels personatges tractats és el dirigent de la ciutat de Saragossa Jimeno Gordo, que el novembre de I 474 havia estat condemnat a mort per l'infant Ferran (el Catòlic), governador general, en un acte que recorda el final de la revolta menestral barcelonina de Berenguer Oller descrit per Bernat Desclot. No seria estrany que un autor menestral se sentís atret per aquesta figura, ja que, en paraules de Martí de Riquer (I985: 393)

Jimeno Gordo es caracteritza com a dirigent ciutadà i popular, poc dúctil a la política reial, i com a cap d'una facció saragossana que podia esdevenir perillosa. Sens dubte això li atragué simpaties entre la menestralia de totes les terres de la Corona, com demostren els termes d'afecte i compassió amb què el tracta el poeta naiper Sant Climent. Allò que foren Bernat de Cabrera i Álvaro de Luna per a la noblesa, que veié en ells dues víctimes de la mutable Fortuna, ho devia veure la menestralia en la mort del jurat de Saragossa Jimeno Gordo.

Encara se’n poden trobar alguns exemples més. El brodador Vicent Ferrandis (fl. València, I5III5I5) participà existosament al certamen de Santa Caterina (València, I5II). Se'n conserven diverses poesies escrites en la segona dècada del segle XVI, tres de les quals es van incloure força més tard al Cancionero general d'Hernando del Castillo, a l'edició d'Anvers de I557 (Ferrando I983: 680-85 i 694; RIALC Rao6obis.I).

Fora de la poesia de certamen, el pintor de retaules Gabriel Mòger (Mallorca, $c$. I380-I438/39) és autor d'una tençó o debat poètic (“Seny'en Ferruç, vos qui tenits procura”) amb l'advocat barceloní, que va ser batlle de Tàrrega, Gabriel Ferrús (fl. I4I6-40), del qual es conserven altres obres. El 
poema, d'un to molt agre, és sobre la indumentària de les dames mallorquines, i probablement va ser escrit cap al tombant del segle XIV al XV (Riquer I95I; Alberni 2003: 3-9; RIALC RaoII2.I).50

Aquests pocs poetes probablement són una mostra d'una realitat més extensa -no és possible dir fins a quin punt- tenint en compte que encara n'hi ha molts, amb obra conservada, que no s'han pogut identificar.

\section{$3 \cdot 3$ Del consum a la creació literària}

Aquests exemples demostren que, en la relació entre els menestrals medievals i la literatura, l'autoria d'obres era un fet marginal i que aquests individus n'eren, principalment, però fins més enllà del que s'ha suposat, sobretot consumidors. Els era més fâcil consumir que crear? O els era més interessant o eficient? O totes dues coses alhora? Deixem ara la possible incidència de la segona qüestió per a més endavant.

Sembla que de tot el comentari anterior es desprèn la conclusió que només alguns menestrals estaven capacitats per crear, no tant per una qüestió de talent o de domini de l'escriptura i de la llengua, sinó sobretot per la formació literària i cultural que havien pogut obtenir. Una formació literària i cultural que, en aquell temps, s'obtenia sobretot als focus politicoculturals de la reialesa, la noblesa i el patriciat urbà. Uns focus, sobretot el més potent, la cort reial, als quals, normalment, els menestrals, per rics que fossin, no solien tenir accés; no almenys de la manera i amb la continuïtat necessàries per poder assimilar aquella formació. Buscant un paral-lelisme, tan imperfecte com es vulgui, els metges medievals dels Països Catalans van ser, sobretot, consumidors d'obra mèdica produïda als grans focus universitaris d'Itàlia o de França, i la raó sempre s'ha buscat en la debilitat dels focus universitaris existents al país, on no podien trobar les sinergies i els estímuls necessaris. Aquesta manca d'accés a un focus universitari, cultural o literari decisiu determinaria els resultats i la capacitació per obtenir-los.

Dos exemples cèlebres, relacionats amb el món dels menestrals, evidencien com n’era d’important el ple accés a aquests focus, principalment a la cort reial, que eren decisius per al decurs no únicament vital, sinó sobretot creatiu, de l’individu. Com el trobador Peire Vidal, Bernat Metge i Andreu Febrer van ser dos escriptors d'una categoria ben diferent dels que s'han esmentat. Tots dos, però, com Peire Vidal, eren d'orígens familiars menestrals: Metge era fill d'un apotecari i Febrer, d'un manegador. El seu destí era seguir els oficis paterns o no allunyar-se'n gaire, però la casualitat va fer que obtinguessin el suport de sengles notaris que els van proporcionar una formació escripturària i llatinista superior i que, decisivament, els van fer entrar a la Cancelleria reial i a la cort (Cabré-Torró 20I5). 


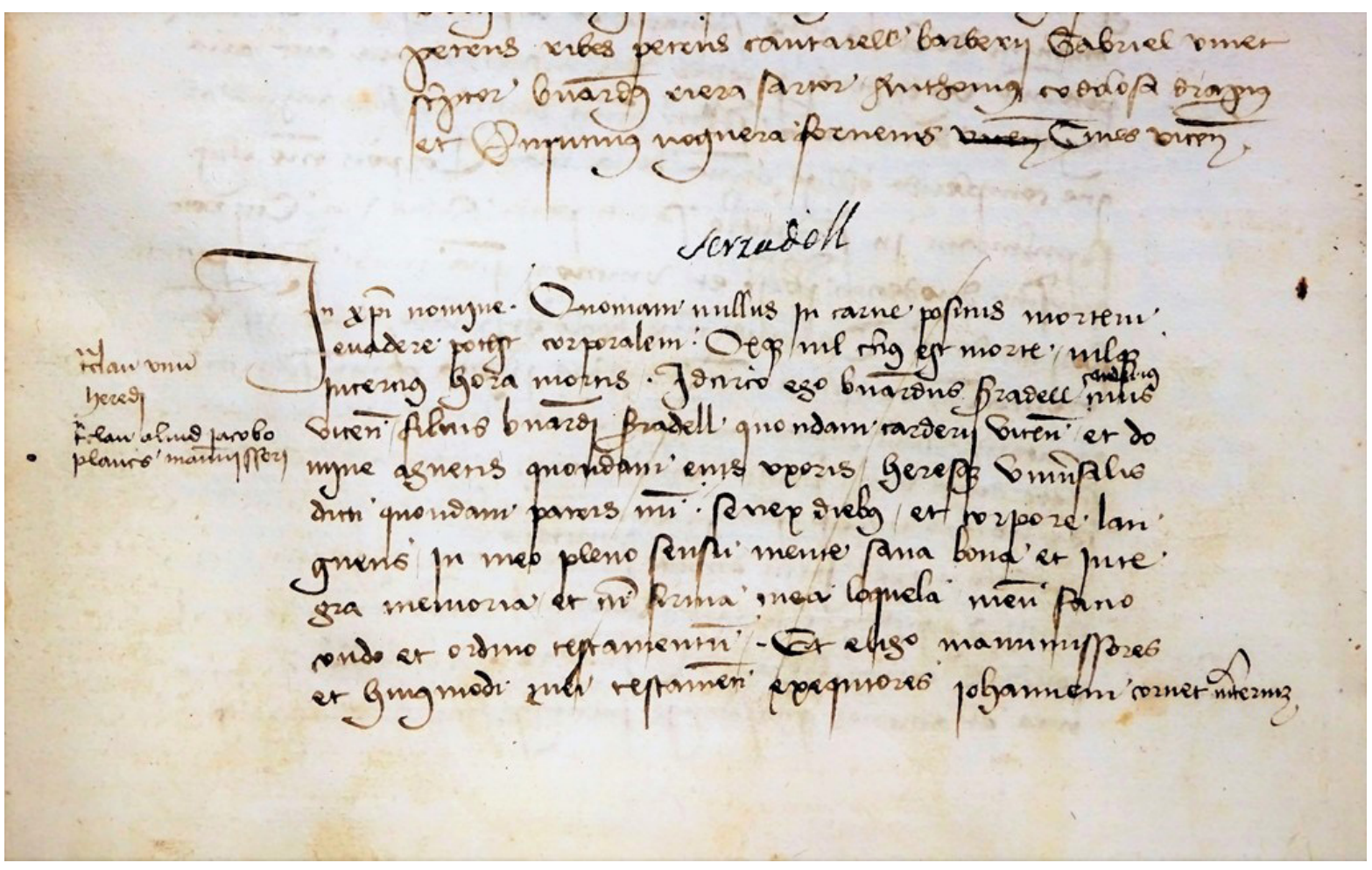

Fig. 7: Inici del testament notarial de Bernat Serradell, carder de Vic (@) ABEV, ACF-3545

[Llibre de testaments I del notari Joan Sallés], f. I5v).

\section{Literatura i promoció social}

$\mathrm{F}$ ins aquí s'ha evidenciat una gran quantitat d'exemples de la relació dels menestrals catalans -aquesta baixa burgesia, que es deia al principi- amb la literatura durant els últims segles medievals $i$ als inicis de l'època moderna. S'ha vist que, havent-se fet amb un cert domini de l'escriptura i havent-se familiaritzat amb el món del llibre, els individus d'aquest sector social posseïen obres literàries a les seves petites biblioteques, les adquirien als encants, les copiaven i les escrivien.

A dia d'avui, l'investigador té a l'abast tot de repertoris documentals que editen o regesten una enorme quantitat d'inventaris de biblioteques privades i altres documents sobre la possessió i la circulació del llibre als Països Catalans durant l'època medieval. Aquests repertoris són d'un altíssim valor per conèixer el món del llibre i la lectura en aquella època, però, en publicar i estudiar només una part dels béns dels individus i en ser complicat fer una recerca per cadascun d'ells, no solen donar prou informació com per valorar l'estatus socioeconòmic real de cada posseïdor. Algunes vegades fa certament la impressió que alguns menestrals, i també "mariners", "pescadors" o "pagesos", devien tenir una potència econòmica notable tot i no pertànyer al sector superior del tercer estament. Només es pot arribar a confirmar aquesta sospita amb l'anàlisi del conjunt dels béns de cada posseïdor de llibres i amb l'obtenció de més dades biogràfiques. Hillgarth (I99I: 42 i ss., doc. 823) fa notar que alguns menestrals de Mallorca, la biblioteca dels quals publica, tenien una projecció mercantil i devien ser més rics que els altres, en particular els dels gremis del sector tèxtil i els sabaters. Ferrer (2OII: I48) comenta, en el cas de la vídua del flequer de València que posseïa el Llibre de Merlí, que "si examinamos detenidamente el inventario deducimos, por la 
descripción de las estancias de la casa y todos los enseres detallados, que pertenece a la burguesía artesana pudiente de Valencia". Martí (2O2I) suposa que pertanyien a aquest sector els "copistes extravagants" d'Eiximenis que estudia, i així s'ha pogut constatar aquí en algun d'aquests casos.

És notable el cas, comentat abans, del blanquer de Barcelona Bernat Nicolau. La confirmació documental del seu nivell benestant va alleugerir la intranquil-litat de la crítica davant la constatació que un simple menestral s’interessés per la Commedia de Dante. Tot i que la potència econòmica de Nicolau no el situava en l'oligarquia per molt que s'hi relacionés, sí que permetia salvar aquells prejudicis. Nicolau, com alguns altres menestrals, pertanyia al sector superior de la petita burgesia, constituït per individus que posseïen obradors molt potents i que potser s'havien bastit una xarxa comercial i havien aconseguit diversificar els seus interessos econòmics. No obstant aquests casos, certs, està per verificar -si és que això fos possible-que tots els menestrals posseïdors d'obres literàries que apareixen a la taula que es publica en aquest article eren benestants, tenien "grans obradors" o se'ls pot assimilar a "comerciants" i a "industrials". Tampoc es coneix el nivell socioeconòmic d'alguns “copistes extravagants” que no s'han pogut documentar prou, com el sabater Antoni Duran o l'esparter Jaume Vilardell. Així i tot, els casos en què s’ha pogut demostrar que el menestral pertanyia al sector superior de la petita burgesia són de gran interès, com es veurà.

Jaume Aurell (I993, 2000, sobretot) ha mostrat com l'estament mercantil de la Barcelona del segle XV estava immers en un procés d'ennobliment del temps lliure íntimament relacionat amb canvis profunds en la mentalitat d'aquest grup social. Aquests canvis tenien l'origen en la necessitat de seguretat material, exacerbada per la crisi, que a poc a poc va portar els mercaders a minimitzar el risc emprenedor i a refugiar-se més i més en els negocis especulatius, comprant béns immobles a la ciutat i a la rodalia, i invertint en renda pública i en censals. Tot plegat serien elements d'un "procés disgregador de l'estament mercantil", que buscava aproximar-se a l'oligarquia dels "ciutadans" (honrats) o "prohoms", els quals feia temps que vivien segons aquests principis.

L'anàlisi de les lectures literàries dels mercaders (Aurell I996: I6I-73) i, en general, la de les seves estratègies socioculturals indica una inclinació creixent per unes formes de vida més pròpies dels nobles i dels ciutadans honrats que de la vida activa i oberta al risc del comerciant dels segles anteriors. En l'àmbit cultural, l'estratègia de legitimació de les seves aspiracions socials va centrar-se en l'ostentació d'un tipus determinat de lectures i de llibres, cada vegada amb més obres d'història i novel-les artúriques o de cavalleria, que els acostava mentalment i socialment al seu objectiu, en ser les lectures i els llibres als quals portaven temps afeccionats els ciutadans honrats i, no cal dir-ho, els nobles. D’altra banda, tot i la primacia de la voluntat d'ostentació, aquestes lectures van exercir un paper decisiu perquè aquest sector social incrementés el seu nivell cultural.

El mateix Aurell (i996: I68-69) constata que els llibres i les obres que contenien eren, per als mercaders de la Barcelona del segle XV, un símbol sociocultural que els proporcionava no tan sols un prestigi sinó també una porta per emular unes formes de vida i uns gustos culturals que els aproximaven als grups socials superiors. A l’època, els espais i les iniciatives culturals que, més endavant, exerciran aquest paper simbòlic eren limitats o inexistents, i per això el llibre va concentrar aquesta funció, més encara tenint en compte que, en ser manuscrit, era un producte molt més exclusiu que no ho seria després amb la impremta.

Entre els mercaders, la còpia de llibres d'aquell perfil que els interessava també formava part de la mateixa estratègia. A tall d'exemple, la tradició manuscrita de la traducció catalana d'Antoni Canals dels Dictorum factorumque memorabilium de Valeri Màxim compta amb dos "copistes extravagants" mercaders: l'apotecari i mercader itàlic instal.lat a València Bartolo de' Cavalli ("Bartol de Cavalls" al manuscrit, a vegades mal interpretat com 'Savalls') que, per encàrrec del cardenal Jaume d’Aragó, 
copià l'obra el I395 per als consellers de Barcelona; i el mercader Ramon Gener, que la començà a copiar a Constantí (Tarragonès) el I4OI i poc després l'acabà a Barcelona..$^{5}$

No forma part dels objectius d'aquest estudi verificar si el panorama que s'ha constatat entre els mercaders de Barcelona és extrapolable a altres ciutats, però no sembla gaire diferent del que es dedueix de l'anàlisi de les biblioteques privades quatrecentistes de València (Ferrer I993) o de Mallorca (Hillgarth I99I). D’altra banda, fa l'efecte que és una tendència que ja venia del segle XIV, filla de la gran crisi baixmedieval que als Països Catalans es feia sentir des del fatídic "mal any primer” de I333, per posar una data indicativa. És una lògica, l’observada per Aurell, que, en l'aspecte que aquí interessa -la cultura com a eina de legitimació social-, no va afectar només els mercaders.

L'anhel de promoció és viu en tots els sectors de la burgesia des del seu mateix naixement i creix, és clar, des del moment que les monarquies busquen el seu suport per a imposar-se a la noblesa, a partir del segle XIII. Quin estament social representen, si no, els herbívors del Llibre de les bèsties (c. 1287-89), que per a Ramon Llull ocupaven llocs i tenien aspiracions contràries a l'ordre tradicional? Sobretot els herbívors grossos, els que més possibilitats tenien d'aconseguir l'objectiu: els "prohoms", els "ciutadans" i, rere d'ells, els mercaders. Per als membres d'aquesta oligarquia, a més d'ocupar posicions clau en la direcció d'aquella nova societat urbana, les possibilitats de fer el salt a l'estament superior, d'ennobliment, no eren una utopia impensable. Per als sectors inferiors, promoció significava passar a una situació més benestant, més ben relacionada, més respectada, a partir de la qual qui sap si les generacions següents podrien fer altres passos i arribar a ingressar als cercles oligàrquics. Les estratègies eren diverses en cada sector, però goso dir que la cultura, l'escriptura i el llibre, la literatura i l'art, hi eren elements força comuns, força útils.

Per a l'oligarquia burgesa, la possessió d'una biblioteca i l'acumulació de llibres responia a una estratègia definida: eren instruments que permetien i asseguraven la promoció social..$^{2}$ L’assimilació del codi cultural nobiliari, també en els gustos literaris, els va semblar un instrument útil per aconseguir-la. ${ }^{33}$ Els llibres d'història, la novel-la artúrica, les obres de cavalleria, però també la poesia de tradició trobadoresca, pel seu antic potencial legitimador de la noblesa, es van fer més i més presents a les seves biblioteques, i van impulsar la còpia, sovint luxosa, de cançoners i d'altres llibres que les contenien i les ostentaven. La influència d'aquestes lectures arribava també a l'antroponímia. És el cas del mercader de Gandia de mitjan segle XV Francesc Tristany de Lleonís. ${ }^{54}$

En la petita burgesia, el segment més actiu a l'hora de posar en pràctica aquestes estratègies era el més acabalat i ben relacionat. No obstant això, suposar que només era aquest sector l'interessat no sembla una hipòtesi fâcil de provar, i m’inclino per pensar que el fenomen va penetrar més profundament en l'estament menestral. Certament, els individus més benestants eren els que notaven a la punta dels dits l'anhelada promoció social. No era estrany, per tant, que fossin especialment ells els més sensibles a totes les estratègies que els ajudessin a aconseguir-la, entre

51. El primer manuscrit, a AHCB, Manuscrits municipals, ms. IG-36, descrit a BITECA manid ı88o; vegeu també Tomasin 2OI9-2O. El segon, a BNE, ms. 8242, descrit a BITECA manid I88I.

52. A part de l'anàlisi d'Aurell per als mercaders i del que s'ha dit des de la història del llibre, F. Gimeno i J. Trenchs (I992), tot i centrar-se en el segle XVI, argumenten el tema des de la història de la cultura escrita.

53. Tavani (I980) presenta el tema, però l'atribueix a “l'afany d'aconseguir ràpidament una validació cultural de llurs aspiracions polítiques [el qual] va impedir els burgesos barcelonins de crear una cultura i una literatura originals comparables a la que havien bastit, el segle XIII i XIV, els burgesos toscans o els picards", que a la llarga els facilitarien les aspiracions de "conquesta del poder polític".

54. Amb les variants, als documents, de Tristany de Lleonís, en Tristany, Francesc Tristany, Francesc de Lleonís àlies Tristany, Lleonís de Tristany (Garcia Oliver-Aparisi-Rangel-Royo 20o9-II: II-III, doc. 247, 252, 256, 275, 279). Vegeu la nota 23 . 
les quals les vies de legitimació que veien en l'assumpció i l'ostenació d'uns gustos literaris i d'uns llibres sobre la matèria. En aquest sector, si a més d’analitzar la documentació conservada prenem en consideració els manuscrits conservats, la còpia personal de llibres valorats sembla tant o més freqüent que entre l'oligarquia i els mercaders, que tenien més recursos per procurar-se còpies d'encàrrec. Per als menestrals, copiar-los personalment podia ser una via doblement efectiva, perquè permetia no només aquella ostentació externa sinó també la d'una implicació personal absoluta, en el tema i, més en general, en l'escriptura i en el producte llibre. La còpia de textos religiosos en vulgar, com els esmentats d'Eiximenis, anava en la mateixa línia perquè demostrava l'assumpció d'aquella nova religiositat urbana que impulsava, identificava i legitimava la burgesia de l'època.

La gran quantitat d'informació recollida a la taula que acompanya aquest article suggereix que el fenomen arribava a sectors no tan benestants de la menestralia, entre els quals també hi ha casos d’antroponímia que seguia la moda literària, com el del barber de Barcelona Lleonís Mestre (vegeu la nota 23). De fet, per a una comprensió correcta d'aquesta informació, convé tenir present que la representativitat social real dels documents conservats és impossible de valorar. D’altra banda, avui s'assumeix que l'interès dels menestrals pels llibres tècnics de l'ofici i per la transmissió escrita del saber tècnic va ser creixent i un fet no gens marginal, encara que, en no ser llibres de valor, la migradesa de dades que un o altre investigador n'ha pogut reunir amb esforç i l'excepcionalitat dels testimonis conservats hagin induït a pensar el contrari. Aquesta implicació -que anava més enllà de la comptabilitat- en l'escriptura i en el llibre, sovint fent-se còpies personals i reunint petites biblioteques, estava directament relacionada amb la revalorització de la tècnica manual impulsada en aquests ambients urbans baixmedievals. Aquesta revalorització de la tècnica era paral-lela a una nova perspectiva científica, portada a Europa pels textos àrabs, que difonia el convenciment que saber més equivalia a ser més, des d'un punt de vista socioprofessional. Saber més, a partir del segle XIII, primer entre els oficis sanitaris i poc després en els altres, s'aconseguia posseint i llegint llibres. No sembla exagerat pensar que aquests processos que els menestrals vivien a l'àmbit tècnic dels seus oficis, que tenien com a comú denominador la interrelació entre l'escriptura i el llibre, d'una banda, i la promoció, de l'altra, influís en la seva valoració d'altres llibres, d'altres lectures. ${ }^{55}$

Però aquelles nombroses atestacions documentals d'obres literàries, en reflecteixen una lectura real per part dels menestrals? O aquests només els acumulaven, sense ser capaços d'entendre’n el contingut, perquè eren conscients de la funció social que feien? En les interpretacions tradicionals de la relació dels menestrals amb la literatura, aquesta última hipòtesi, encara que no es digui directament, és la preferida. S'ha argumentat que la compra de llibres altament especialitzats (teològics, jurídics, mèdics, etc.) als encants -que Hernando (2000) ha fet veure que era una inversió relacionada amb la pràctica del crèdit- provaria que no podien entendre el que tenien a les seves biblioteques. També ho provaria la possessió d'obres en altres llengües (cas de l'estanyer valencià Guillem Brinquet, a la taula) i, fins i tot, el fet que, als inventaris, els llibres a vegades es trobessin en arques tancades o que, quan es conserva l'inventari i l'encant d'un mateix individu, no apareguin en aquest darrer (Ferrer I993: I8I-82; Ferrer 20II: I45, I48-49).

Cap d'aquests arguments em sembla que avali necessàriament la segona hipòtesi. Per contra, la mateixa quantitat d'atestacions localitzades i les còpies personals conservades semblen poderosos arguments a favor de la primera. Alguns autors (Bec I984: I5-I6) pensen que el mateix preu del llibre

55. Vegeu supra el capítol I, Els menestrals, lectors de literatura. A Cifuentes 2oooa s'analitza el cas d'un barbercirurgià de Barcelona del segle XV, els seus béns i la seva petita però selecta biblioteca de llibres tècnics en català, el fill cirurgià del qual va aconseguir tenir formació mèdica universitària, va reunir una biblioteca molt més extensa de llibres llatins i va ser conseller de Barcelona al tombant del segle XV. 
manuscrit, i l'esforç i el temps que calia per confeccionar-lo, limitava els casos en què s’adquiria amb finalitats "ornamentals" i afavoria que es fes per una "necessitat específica", que passava per la lectura. No obstant això, sembla prudent pensar que la realitat devia ser diversa. Certament, a l'hora d'analitzar aquestes fonts documentals, cal admetre d'entrada que, com sempre, llibre posseït no és igual a llibre llegit, però, així i tot, il·lustra sobre els gustos literaris que hi havia a la casa. Ara bé, això també presenta un altre problema, que és l'existència de llibres heretats. Als documents, poques vegades s'hi diu, algunes altres es pot intuir, però en general és impossible saber si els llibres eren del difunt o dels seus ancestres. Per al tema d'aquest article, però, aquest problema és menor, perquè, al mostrar una continuïtat entre els posseïdors, no en canvia la tesi..$^{5}$

D'altra banda, s'ha de tenir present que els llibres consignats en un inventari post mortem reflecteixen un estat cultural que sol ser anterior a la mort del posseïdor, atès que l'adquisició dels llibres pot haver-se efectuat força abans (per a Bec 1984: I5, cap a una vintena d'anys abans). Els inventaris poden incloure llibres d'altres persones, deixats en préstec al difunt o bé retinguts com a garantia d'un crèdit. Atès que la finalitat del document era valorar els béns del titular, aquests extrems sempre s'hi indiquen. Un dels documents recollits a la taula fa referència al préstec d'un llibre entre particulars: el I440 el moneder Guillem Queralt recuperava unes Històries troianes que havia posat a disposició ("acomodaveram") de Galceran Carbó, un "ciutadà" de Barcelona que havia estat conseller en cap el I43O; un intercanvi en el qual, evidentment, hi havia un interès cultural -potser la còpia de l'exemplar- i no econòmic. Tot i que no coneixem la posició social exacta del moneder, ${ }^{57}$ el document suggereix una relació fluïda entre els sectors socials urbans quant a l'intercanvi cultural.

Assumir els gustos culturals propis de l'estament superior no únicament conferia “prestigi”, com sovint els investigadors s'han limitat a dir, sinó que formava part de les estratègies per aconseguir la promoció social. La idea vigent és que tots els sectors de la burgesia imitaven els gustos culturals de la cort, que en literatura privilegiaven les obres d'història, artúriques, cavalleresques i una lírica amorosa de tradició trobadoresca (Cingolani I99O-9I). Tot i que, com s’ha dit al principi, la visibilitat documental de la literatura és escassa i problemàtica -molt en particular als tan emprats inventaris de béns-i això no sempre es té present, alguns documents semblen reflectir efectivament aquesta via de transmissió. Els individus adduïts sempre tenien algun vincle amb la cort, però entre els menestrals els casos són ben exigus. Dels recollits a la taula, només hi ha el del perpunter de Barcelona Miquel Gombau, de la cambra del rei Joan I, que el r39I va obtenir del monarca el Llibre de Merlí en préstec. $5^{8}$ Per una via indirecta, també procedia de l'entorn de la cort l'exemplar de Lo somni de Bernat Metge que el I463 va comprar l'esperoner Gabriel Tries a l'encant dels béns d'un lloctinent de l'escrivà de ració del rei.

Fa l'efecte, per les dades recollides a la taula i per tot el que s'ha anat dient fins aquí, que cal introduir matisos en aquella idea d'una procedència cortesana de les lectures literàries de tota la burgesia. És l'oligarquia dels "prohoms" o "ciutadans", més la classe mercantil, la que encaixa en aquesta idea, que no deixa de ser una generalització, però no sembla ser el cas dels menestrals. Com s'ha vist reiteradament en aquest article, els menestrals tenien la vista posada en el sector superior

56. Per als llibres heretats, vegeu les reflexions de Gimeno-Trenchs (I992: 229), matisades per Iglesias (I996a: 50), que subratlla la continuïtat en la família dels gustos que il·lustren. En la mateixa línia s’havia expressat Bec (I984: I5-I6).

57. En una seca, els moneders feien l'acció d'encunyar la moneda. Deu ser el "P. Guillem Queralt" que apareix en la nòmina dels moneders de la seca de Barcelona de I422 (Salat I8I8: II, 52, doc. 49). En aquesta nòmina, els moneders ocupen el penúltim lloc entre els treballadors de la seca.

58. L’àpoca publicada per Hernando (I995: doc. 400), ha de correspondre al manament del rei editat per Rubió (I908-2I: II, doc. 338), tot i que en aquest s'ordena lliurar el llibre “a Pujolet, de la nostra cambra”, probablement un àlies (he verificat el document original). 
de la burgesia, no pas en la noblesa. En gustos culturals, en lectures literàries, qui miraven d'emular, perquè fessin els efectes socials que esperaven, era l'elit burgesa i mercantil, els “ciutadans" i mercaders, que eren els que reproduïen els gustos nobiliaris i cortesans. Aquests gustos arribaven al sector menestral de manera indirecta.

Malgrat això, no sembla que es pugui despatxar el tema de les lectures literàries de la burgesia amb la idea fâcil d'una imitació general, directa o indirecta, dels gustos culturals que provenien de la cort i sentenciant que la burgesia catalana no va ser capaç d'impulsar un univers literari i cultural autònom, propi del seu estament. No és aquest el lloc de determinar tal cosa, molt més complexa que els objectius marcats en aquest article, però sembla evident que, per fer-hi llum, cal obrir el ventall dels textos a considerar -els que interessaven a aquell grup social-i no únicament tenir en compte els que corresponen al que avui entenem per "belles lletres". Si es fa així, les lectures relacionades amb aquella nova religiositat urbana, que anaven més enllà del banderí que era Eiximenis, però també amb el dret, amb la salut o amb la filosofia moral i natural, dibuixen un quadre molt més complet en el qual potser són més intel-ligibles algunes obres literàries, fins i tot algunes que aparentment procedien dels gustos cortesans (com una Història del sant Graal tan "franciscana" o les que neixien del col-lectiu dels notaris). Per a una bona intel-ligibilitat, convé assumir que el context d'origen d'una obra o traducció, no la condemna a ser compresa en aquest mateix entorn per sempre més: podia ser llegida, més endavant, en contextos diferents i podia ser que els nous lectors, esdevinguts "copistes extravagants", no fossin receptors passius, sinó intervencionistes. És tot aquest conjunt de textos, "literaris" i "no literaris", que actuaven com a legitimadors de la burgesia i de la vida urbana, i no pas alguns sí i altres no o mal entenent-los, anacrònicament, com a matèries incomunicades.

Els menestrals formaven part d'aquest context, d'aquest univers literari i cultural urbà, interrelacionat -com no podia ser d'altra manera- amb els gustos de l'elit burgesa, de l'estament nobiliari i del cercle cortesà. Entre ells hi traspua igualment una recepció que també podia ser activa i una construcció cultural autònoma, especialment visible en els autors menestrals que, per minsos que fossin, mereixerien una valoració més justa.

\title{
5 Agraïments
}

\begin{abstract}
A Anna Alberni (Universitat de Barcelona-ICREA), Lola Badia (Universitat de Barcelona), Miriam Cabré (Universitat de Girona), Antònia Carré (Universitat Oberta de Catalunya), Montse Català (Sabadell), Rocío Da Riva (Universitat de Barcelona), Sadurní Martí (Universitat de Girona), Josep Moran (Universitat de Barcelona) i Carles Vela (Barcelona).
\end{abstract}

\section{Abreviatures emprades}

$\mathrm{ACB}=$ Arxiu de la Catedral de Barcelona

$\mathrm{ADPO}=$ Archives Départementales des Pyrénées Orientales (Perpinyà)

$\mathrm{AHCB}=$ Arxiu Històric de la Ciutat de Barcelona

AHPB $=$ Arxiu Històric de Protocols de Barcelona

AHSCSP = Arxiu de l'Hospital de la Santa Creu i de Sant Pau (Barcelona)

$\mathrm{BC}=$ Biblioteca de Catalunya (Barcelona) 
BNE $=$ Biblioteca Nacional de España (Madrid)

BPEB = Biblioteca Pública Episcopal del Seminari de Barcelona

BRUB = Biblioteca de Reserva de la Universitat de Barcelona

Escorial $=$ Real Biblioteca del Monasterio de San Lorenzo de El Escorial

HSA = Hispanic Society of America (Nova York)

MNAC = Museu Nacional d'Art de Catalunya (Barcelona) 


\section{${ }_{7}$ Obres citades}

Adroher, Miquel. 2005-06. 'La Stòria del Sant Grasal, version franciscaine de la Queste del Saint Graal, Butlletí de la Reial Acadèmia de Bones Lletres de Barcelona, 50: 77-II9 < https://tinyurl. com/ycutpbp 4 >

Ainaud de Lasarte, Joan. I993. 'Jaume Huguet i Barcelona abans del I448', in Jaume Huguet, 500 anys, ed. by Eulàlia Jardí and Rosa Alcoy (Barcelona: Generalitat de Catalunya, Departament de Cultura), pp. 48-53

Alberni, Anna. 2003. 'Gabriel Ferrús i els seus interlocutors literaris: noves dades sobre un poeta barceloní del segle Xv', Romance Philology, 57.I: I-26 <https://www.jstor.org/stable/4474I85I >

Almenar Fernández, Luis. 20I8. 'Lo dret de l'inventari ben fet: el context normatiu dels inventaris valencians i les seues implicacions per a la història del consum a l'Edat Mitjana', in Els inventaris 'post-mortem': una font per a la història econòmica i social, ed. Belén Moreno Claverías (Girona: Associació d'Història Rural de les Comarques Gironines; Centre de Recerca d'Història Rural de la Universitat de Girona; Documenta Universitaria), pp. I7-35 <https://tinyurl.com/6er4wefc>

Alòs-Moner i de Dou, Ramon d'. I9IO. 'Inventaris de castells catalans (sigles XIV-XVI)', Estudis Universitaris Catalans, 4: 129-92 <https://tinyurl.com/429yez53 $>$

Aurell, Jaume. 1996. Els mercaders catalans al Quatre-cents: mutació de valors i procés d'aristocratització a Barcelona (1370-1470) (Lleida: Pagès)

Aurell, Jaume. 2000. 'Culture marchande et culture nobiliaire à Barcelone au $\mathrm{XV}^{\mathrm{e}}$ siècle', Revue Historique, 302.I(6r3): 33-53 〈https://www.jstor.org/stable/40956607>

Badia, Lola; Santanach, Joan; Soler, Albert. 20ıo. 'Els manuscrits lul-lians de primera generació als inicis de la scripta librària catalana', in Translatar i transferir: la transmissió dels textos i el saber (1200-1500), ed. by Anna Alberni, Lola Badia and Lluís Cabré (Santa Coloma de Queralt: Obrador Edèndum; Universitat Rovira i Virgili), pp. 6I-90 <https://tinyurl.com/8c6ekd7z $>$

Badia, Lola; Martí, Sadurní. 20I3. 'Edat mitjana i literatura', in Història de la Literatura Catalana, ed. by Àlex Broch (Barcelona: Enciclopèdia Catalana; Barcino; Ajuntament de Barcelona), vol. r: Literatura medieval, I: Dels orígens al segle XIV, ed. by Lola Badia, pp. I7-46

Batlle i Prats, Lluís. I969. 'Noticias de libros antiguos de servidores de la Catedral de Gerona (I335' I594)', Hispania Sacra, 22: 425-46

Bec, Christian. 1984. Les Livres des florentins (1413-1608) (Firenze: Leo S. Olschki)

BITECA. Bibliografia de Textos Antics Catalans, Valencians i Balears, ed. by Gemma Avenoza, Lourdes Soriano and Vicenç Beltran (Berkeley: University of California) $<$ https://bancroft. berkeley.edu/philobiblon/biteca ca.html > [consulta 24-5-2O2I]

Bohigas, Pere. 196I. 'Un manuscrit dantesc copiat a Catalunya', Estudis Romànics, 9: 251-67 <https://tinyurl.com/3f 4 hswyj $>$

Bosch i Besó, Ramon. 200I. Història del poble de Sunyer (Rubí: Impr. Torrella)

Bresc, Henri. 1971. Livre et société en Sicile (1299-1499) (Palermo: Centro di Studi Filologici e Linguistici Siciliani) 
Cabré, Miriam; Espadaler, Anton. 2013. 'La narrativa en vers', in Història de la Literatura Catalana, ed. by Àlex Broch (Barcelona: Enciclopèdia Catalana; Barcino; Ajuntament de Barcelona), vol. I: Literatura medieval, I: Dels orígens al segle XIV, ed. by Lola Badia, pp. 297-372

Cabré, Lluís; Torró, Jaume. 20I5. 'La data de naixement de Bernat Metge i d'Andreu Febrer, notaris i escriptors', dins Studia mediaevalia Curt Wittlin dicata / Mediaeval Studies in Honour Curt Wittlin / Estudis medievals en homenatge a Curt Wittlin, ed. by Lola Badia, Emili Casanova and Albert Hauf (Alacant: Institut Interuniversitari de Filologia Valenciana), pp. 8I-85 $<\underline{\text { https: // }}$ tinyurl.com/5tu6t6dc>

Cáceres Nevot, Juanjo. 2003. 'El llibre de comptes de Guillem Fagaló, paraire: un testimoni de la comptabilitat dels menestrals barcelonins en el segle XIV', in El món urbà a la Corona d'Aragó del 1137 als decrets de Nova Planta: XVII Congrés d'Història de la Corona d'Aragó / Congreso de Historia de la Corona de Aragón, Barcelona-Poblet-Lleida 2ooo, ed. by Salvador Claramunt (Barcelona: Universitat de Barcelona), I: 29I-300

Cifuentes i Comamala, Lluís. 2000a. 'La promoció intel-lectual i social dels barbers-cirurgians a la Barcelona medieval: l'obrador, la biblioteca i els béns de Joan Vicenç (fl. I42I-I464)', Arxiu de Textos Catalans Antics, 19: 429-79 <https://tinyurl.com/yukszbfg>

Cifuentes i Comamala, Lluís. 2ooob. 'Notícia d'una traducció catalana de la Chirurgia d'Henri de Mondeville', Arxiu de Textos Catalans Antics, I9: 587-99 <https://tinyurl.com/4h74te56 $>$

Cifuentes i Comamala, Lluís. 20o6. La ciència en català a l'Edat Mitjana i el Renaixement, 2nd edn (Barcelona: Universitat de Barcelona; Palma: Universitat de les Illes Balears)

Cifuentes i Comamala, Lluís. 20I6. 'El receptari mèdic baixmedieval i renaixentista: un gènere vernacle', in Els manuscrits, el saber i les lletres a la Corona d'Aragó, 1250-1500, ed. by Lola Badia et al. (Barcelona: Publicacions de l'Abadia de Montserrat), pp. IO3-6o $<\underline{\text { https://tinyurl. }}$ com/2365dne8 $>$ [consulta 24-5-202I]

Cifuentes i Comamala, Lluís. 2O2I. 'Les miscel-lànies mèdiques medievals en català: una proposta de classificació', dins Sabers per als laics: vernacularizació, formació, transmissió (Corona d'Aragó, 1250-160o), ed. by Isabel Müller and Frank Savelsberg, Beihefte zur Zeitschrift für romanische Philologie, 463 (Berlin: De Gruyter), pp. 255-90

Cifuentes i Comamala, Lluís; Córdoba de la Llave, Ricardo. 20II. Tintorería y medicina en la Valencia del siglo Xv: el manual de Joanot Valero, Anejos del Anuario de Estudios Medievales, $7 \mathrm{O}$ (Barcelona: CSIC, Institució Milà i Fontanals)

Cingolani, Stefano M., 1990-9I. 'Nos en leyr tales libros trobemos plazer e recreation: l'estudi sobre la difusió de la literatura d'entreteniment a Catalunya els segles XIV i XV', Llengua \& Literatura, 4: 39-I27 <https://go.uv.es/oGTazVd>

Cinotti, Riccardo; Codonyer Sòria, Pilar. 2003. 'I manoscritti catalani delle Històries troianes: saggio codicologico per la creazione di un catalogo unico delle testimonianze medievali della fortuna troiana in Iberia', Quaderns de Filologia: Estudis Literaris, 8: I5 $^{\mathrm{I}}-7 \mathrm{O}$

Colón, Germà; Garcia, Arcadi. 20or. Llibre del Consolat de Mar: edició del text de la Real de Mallorca amb les variants de tots els manuscrits coneguts, 2nd edn (Barcelona: Fundació Noguera; Cambra de Comerç de Barcelona)

Cortes. I896-r922. Cortes de los antiguos Reinos de Aragón, Valencia y Principado de Cataluña..., 26 vols (Madrid: Real Academia de la Historia) < https://tinyurl.com/kz84362m> 
Cruselles Gómez, José M. a 2004 . 'Las fuentes notariales y la investigación histórica: problemas de explotación de datos y análisis de la actividad notarial', in Aragón en la Edad Media: perspectivas actuales sobre las fuentes notariales de la Edad media (Zaragoza: Universidad de Zaragoza), pp. 7-34 <https://tinyurl.com/a4p4p6bz>

Derolez, Albert. 1979. Les Catalogues de bibliothèques, Typologie des Sources du Moyen Âge Occidental, 3I (Turnhout: Brepols)

Díaz Martí, Carles. 20o6. Bertran Nicolau, fundador de Sant Jeroni de la Murtra (Badalona: Museu de Badalona)

Dufourcq, Charles-Emmanuel. 1974. 'Aspects internationaux de Majorque durant les derniers siècles du Moyen Âge’, Mayurqa, II: 5-52 <https://tinyurl.com/ykrzzucu $>$

Eiximenis DB, coord. per Sadurní Martí (Girona: Universitat de Girona, 20IO-) $<\underline{\text { https: / / eiximenis. }}$ narpan.net/> [consulta 24-5-202I]

Faulhaber, Charles B. 1987. Libros y bibliotecas en la España medieval: una bibliografía de fuentes impresas (Londres: Grant \& Cutler)

Ferrando Francés, Antoni. 1983. Els certàmens poètics valencians del segle XIV al XIX (València: Institut de Literatura i Estudis Filològics, Institució Alfons el Magnànim)

Ferrer Gimeno, M. ${ }^{a}$ Rosario. 1993. La lectura en Valencia (1416-1474): una aproximación histórica (unpublished doctoral thesis, Universitat de València)

Ferrer Gimeno, M. ${ }^{a}$ Rosario. 2OII. 'Presencia del ciclo artúrico en las bibliotecas bajomedievales de la ciudad de Valencia (I4I6-I 474)', Revista de Literatura Medieval, 23: I37-52 <http:// hdl.handle. net/IOOI7/I264I $>$

Ferrer i Mallol, Maria Teresa. 1998. 'Després de la mort: l'actuació d'algunes marmessories a través d'un manual del notari barceloní Nicolau de Mediona (I437-I438)', Analecta Sacra Tarraconensia, 71: 28I-325 <https://tinyurl.com/2tja4f6b $>$

Ferrer i Mallol, Maria Teresa; Vela i Aulesa, Carles. 20I4. 'Un mercader italià a la cort catalanoaragonesa: Luchino Scarampi', Acta Historica et Archaeologica Mediaevalia, 32: 30I-478 $<\underline{\text { https://tinyurl.com/yzw655yj }>}$

Fuente, Isabel de la. 1997. 'La producció d'un argenter barceloní a través del seu llibre de comptabilitat: Miquel Bofill (I45O-I46o)', D'Art, 23: 207-29 <https://tinyurl.com/2h6bkgaa $>$

Garcia-Oliver, Ferran; Aparisi, Frederic; Rangel, Noelia; Royo, Vicent (eds.). 20o9-II. Hug de Cardona: col-lecció diplomàtica, 1407-1482, 3 vols, Fonts Històriques Valencianes, 42 (València: Universitat de València)

Garcia Sanz, Arcadi. 1968. 'Un nuevo códice mallorquín del Llibre del Consolat de Mar', Anuario de Historia del Derecho Español, 38: 635-39<https://tinyurl.com/5msm3xpt $>$

Gilson, Simon, 200I. 'Medieval Science in Dante's Commedia: Past Approaches and Future Directions', Reading Medieval Studies, 27: 39-77 < https://tinyurl.com/3iz8ad3d>

Gimeno Blay, Francisco M. 1991. 'A propósito del manuscrito vulgar del Trescientos: el Escurialense K.I.6 y la minúscula cursiva libraria de la Corona de Aragón’, Scrittura e Civiltà, I5: 205-45

Gimeno Blay, Francisco M.; Trenchs Òdena, Josep, I992. 'Libro y bibliotecas en la Corona de Aragón (siglo XVI)', in El libro antiguo español: actas del segundo coloquio internacional, Sevilla 1989, ed. by María Luisa López-Vidriero and Pedro M. Cátedra (Salamanca: Universidad de 
Salamanca; Madrid: Biblioteca Nacional; Sociedad Española de Historia del Libro), 2O7-39 $<\underline{\text { https://tinyurl.com/fha8tyt8 }>}$

Gimeno Blay, Francisco M. 2007. 'Entre el autor y el lector: producir libros manuscritos en catalán (siglos XII-XV)', Anuario de Estudios Medievales, 37.I: 305-66 [2nd edn, translated and slightly expanded, of: 'Produir llibres manuscrits catalans (s. XII-XV)', in Literatura i cultura a la Corona d'Aragó (s. XIII-XV), ed. by Lola Badia; Miriam Cabré; Sadurní Martí (Barcelona: Curial; Publicacions de l’Abadia de Montserrat, 2002), pp. II5-49] <https://doi.org/IO.3989/ aem.2007.v37.iI.4I $>$

Gómez, Francesc J. 20I4. ElTractat de les penes particulars d'infern de Joan Pasqual: estudi i edició crítica (unpublished doctoral thesis, Universitat de Girona) $<$ http://hdl.handle. net/I0803/I35057>

Gómez, Francesc J. 20I6. 'Lo Dant o la glosa: aparats exegètics de la Commedia en la Catalunya de mitjan segle XV', dins Els manuscrits, el saber i les lletres a la Corona d'Aragó, 1250-1500, ed. by Lola Badia et al. (Barcelona: Publicacions de l'Abadia de Montserrat), pp. I6I-94< $\underline{\text { https://tinyurl. }}$ com/yjfyevi3>

Goujaud, Émilie. 20IO. 'Les Bibliothèques perpignanaises à la fin du Moyen Âge: approche sociale du lecteur roussillonnais', in Le Livre dans la région toulousaine et ailleurs... au Moyen Áge, ed. by Sophie Cassagnes-Brouquet and Michelle Fournié (Toulouse: CRNS; Université de ToulouseLe Mirail), pp. I83-200

Guixeras, David; Renedo, Xavier (ed.). 2005. Francesc Eiximenis Llibres, mestres i sermons: antologia de textos, Biblioteca Barcino, 2 (Barcelona: Barcino)

Hernando i Delgado, Josep. 1993-97. 'L'ensenyament a Barcelona (segle XIV): documents dels protocols notarials', Arxiu de Textos Catalans Antics, I2 (I993): I4I-27I; I6 (I997): I3I-298

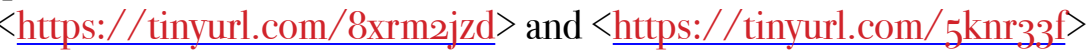

Hernando i Delgado, Josep. 1995. Llibres i lectors a la Barcelona dels. XIV, 2 vols (Barcelona: Fundació Noguera)

Hernando i Delgado, Josep. 20oo. 'Crèdit i llibres a Barcelona, segle XIv: els contractes de venda de rendes (censals morts i violaris) garantits amb vendes simulades de llibres. El llibre, instrument econòmic i objecte de cultura', Estudis Històrics i Documents dels Arxius de Protocols, 18: 7-222 $<\underline{\text { https://tinyurl.com/p5fsojgj }>}$

Hernando i Delgado, Josep. 2003. Els esclaus islàmics a Barcelona: blancs, negres, llors i turcs, de l'esclavitud a la llibertat (s. XIV), Anejos del Anuario de Estudios Medievales, 25 (Barcelona: CSIC, Institució Milà i Fontanals)

Hernando i Delgado, Josep. 2005. 'Instruere in litteris, servire et docere officium: contractes de treball, contractes d'aprenentatge i instrucció de lletra, gramàtica i arts liberals en la Barcelona del segle Xv', Acta Historica et Archaeologica Mediaevalia, 26: 945-84 <https://tinyurl.com/ kuj539s5

Hernando i Delgado, Josep. 2007. 'Obres de Francesc Eiximenis en biblioteques privades de la Barcelona del segle Xv', Arxiu de Textos Catalans Antics, $26:$ 385-568 <https://tinyurl.com/ stpsfnzn>

Hillgarth, Jocelyn N. 1991. Readers and Books in Majorca (1229-1550), 2 vols (Paris: CNRS, Institut de Recherche et d'Histoire des Textes) 
Iglesias Fonseca, J. Antoni. I993. 'El llibre a la Catalunya baix-medieval: notes per a un estat de la qüestió', Faventia, I5.2: 39-73 <https://tinyurl.com/4ucy749d $>$

Iglesias Fonseca, J. Antoni. 1996a. Llibres i lectors a la Barcelona del s. XV: Les biblioteques de clergues, juristes, metges i altres ciutadans a través de la documentació notarial (anys 13961475) (unpublished doctoral thesis, Universitat Autònoma de Barcelona) $<\underline{\text { http: } / / \text { hdl.handle. }}$ net/10803/5549>

Iglesias Fonseca, J. Antoni. 1996b. 'Livres et lecteurs à Barcelone au Xve siècle: l'exemple des artisans', Scriptorium, 50.2: 380-89 <https://tinyurl.com/358a572m>

Iglesias Fonseca, J. Antoni. 200I. 'El bibliòfil Bernat d’Esplugues († I433), notari i escrivà del Consell de la ciutat', Barcelona Quaderns d'Història, 5: 57-78 <https://tinyurl.com/mjpruwtij $>$

Junyent, Eduard. 1943. "Repertorio de noticias sobre manuscritos catalanes de la "Cúria fumada" de Vich', Analecta Sacra Tarraconensia, I6.I: 57-86 < $\underline{\text { https://tinyurl.com/2mxb2aat }>}$

Lencina Pérez, Xavier. 1998. 'Espais i objectes quotidians: els inventaris post mortem catalans en el context europeu', Pedralbes, I8.I: 303-Io $\langle\underline{\text { https://tinyurl.com/sbkbx2ww }>}$

Llobet i Portella, Josep M. I997. 'Llibres esmentats en alguns inventaris notarials cerverins del segle xv', Arxiu de Textos Catalans Antics, I6: 405-I5 <https://tinyurl.com/2gukxbpv>

Llompart, Gabriel. 1975-77. 'El llibre català a la casa mallorquina (I350-I55O)', Analecta Sacra Tarraconensia, 48 (I975): 193-240; 49-50 (1976-77): 57-II4 <https://tinyurl.com/2frhkwsc> and <https://tinyurl.com/44zdt6ah>

Madurell i Marimon, Josep M. I949-52. 'El pintor Lluís Borrassà: su vida, su tiempo, sus seguidores y sus obras', Anales y Boletín de los Museos de Arte de Barcelona, 7 (1949): 9-325; 8 (1950): 9-387; IO (1952): 9-365 <https://tinyurl.com/2n73jmty >, <https://tinyurl.com/z7n44Zr4 > and $<\underline{\text { https://tinyurl.com/h7bekxbu }>}$

Madurell i Marimon, Josep M. 1979-82. 'Documents culturals medievals (13O7-I485): contribució al seu estudi', Boletín de la Real Academia de Buenas Letras de Barcelona, 38: 30I-473 < https:// tinyurl.com/2nwsap2n>

Madurell i Marimon, Josep M.; Rubió i Balaguer, Jordi. I955. Documentos para la historia de la imprenta y librería en Barcelona (1474-1553) (Barcelona: Gremios de Editores y Libreros y de Maestros Impresores)

Mandingorra Llavata, M. ${ }^{a}$ Luz. 1989. Leer en la Valencia del Trescientos: el libro y la lectura en Valencia a través de la documentación notarial (1300-1410) (unpublished doctoral thesis, Universitat de València) <http://hdl.handle.net/I0550/38487>

Mañé i Mas, Maria Cinta; Rovira i Solà, Manuel. 2005-I3. Catàleg dels pergamins municipals de Barcelona, 7 vols (Barcelona: Arxiu Històric de la Ciutat) < https://tinyurl.com/4pmmnd8k $>$

Martí, Sadurní. 1997. 'El cançoner del marquès de Barberà $\left(S_{1} / B M i\right)$ : descripció codicològica', Boletín Bibliográfico de la Asociación Hispánica de Literatura Medieval, II: $463-502<\underline{\mathrm{https}}$ // tinyurl.com/yhxzgwhm> [consulta 24-5-202I]

Martí, Sadurní. 2O2I. 'Notes sobre copistes extravagants: Antoni Duran i el Llibre dels àngels de Francesc Eiximenis', in Lectures de comparatiste, quatre millénaires de littérature mondiale: Études offertes a Roy Rosenstein, ed. by Danielle Buschinger, Anne Ibos-Augé and Martine Marzloff (Amiens: Centre d'Études Médiévales), in press 
Martínez Romero, Tomàs (ed.). I995. L.A. Sèneca Tragèdies: traducció catalana medieval amb comentaris del segle XIV de Nicolau Trevet, 2 vols, Els Nostres Clàssics, B I4-I5 (Barcelona: Barcino)

Miquel i Planas, Ramon (ed.). r9ı6. Les 'Històries troyanes' de Guiu de Columpnes traduides al català en el XIven segle per en Jacme Conesa, Biblioteca Catalana (Barcelona: L’Avenç) < $\underline{\text { https:// }}$ archive.org/details/leshistoriestroyoocolo $>$

MNA. Manual de novells ardits, vulgarment apellat Dietari del Antich Consell barceloní, ed. by Frederic Schwartz i Luna, Francesc Carreras i Candi and Pere Voltes i Bou, 28 vols (Barcelona: Imprempta de Henrich y Cia.; Instituto Municipal de Historia, I892-I975) < $\underline{\text { https: / tinyurl.com/ }}$ erdt4n $45>$

Nebbiai-Dalla Guarda, Donatella. 1992. I documentiper la storia delle biblioteche medievali (secoli $(X-X V)$ (Roma: Jouvence)

Obarrio Moreno, Juan Alfredo. 2005. 'La recepció del beneficium inventarï en les fonts i en la doctrina catalana', Revista de Dret Històric Català, 5: 6I-97 <https://tinyurl.com/ageqrg68>

Pacheco, Arseni. I97I. Testament de Bernat Serradell, de Vic, Els Nostres Clàssics, A ro3 (Barcelona: Barcino)

Pagarolas i Sabaté, Laureà. 2004. 'Tipología documental y posibilidades de aprovechamiento histórico de los libros notariales catalanes', Aragón en la Edad Media: perspectivas actuales sobre las fuentes notariales de la Edad media (Zaragoza: Universidad de Zaragoza), pp. 47-82 < $\underline{\text { htps:// }}$ tinyurl.com/a 4 p4p6bz>

Perujo Melgar, Joan M. 200o. 'Prolegòmens per a una edició crítica de la traducció catalana de la Historia destructionis Troiae de Guido delle Colonne', in Actas del VIII congreso internacional de la Asociación Hispánica de Literatura Medieval, Santander 1999, ed. by Margarita Freixas and Silvia Iriso (Santander: Gobierno de Cantabria; Asociación Hispánica de Literatura Medieval), II: I469-86 <https://tinyurl.com/2fjhp8zw $>$

Perujo Melgar, Joan M. 20I5. Les 'Històries troianes' de Jaume Conesa, traducció catalana de la 'Historia destructionis Troiae' de Guido delle Colonne: estudi i edició (unpublished doctoral thesis, Universitat d'Alacant) $\langle\underline{\text { http: } / / h d l . h a n d l e . n e t / I O O 45 / 65 I 27 ~}>$

Renedo i Puig, Xavier. r993. 'Llegir i escriure a la tardor medieval', in Actes del novè col-loqui internacional de llengua i literatura catalanes, Alacant-Elx 1991, ed. by Rafael Alemany, Antoni Ferrando and Lluís B. Meseguer (Barcelona: Publicacions de l'Abadia de Montserrat), II: 209-22 $<\underline{\text { https://tinyurl.com/5sm3pjz7 }>}$

Riera i Sans, Jaume. 2003. 'Conesa, Jaume', in Diccionari d'historiografia catalana, ed. by Antoni Simon i Tarrés (Barcelona: Enciclopèdia Catalana), p. 363

Riquer, Martí de. 195I. 'Gabriel Ferruç y Guerau de Massanet, poetas catalanes del siglo Xv: estudio y edición’, Boletín de la Sociedad Castellonense de Cultura, 27: I48-76 i 234-57 < $\underline{\text { https:/ / tinyurl. }}$ $\underline{\mathrm{com} / \mathrm{xzh}_{55} \mathrm{ce}_{5}>}$

Riquer, Martí de. 1975. Los trovadores: historia literaria y textos, 3 vols (Barcelona: Planeta)

Riquer, Martí de. 1985 . 'El poeta Joan de Sant Climent', in Homenatge a Antoni Comas: miscel-lània in memoriam (Barcelona: Universitat de Barcelona, Facultat de Filologia), pp. 304-389

Rius, Josep. I930. 'L'inventari dels béns d'Arnau Cescomes, arquebisbe de Tarragona', Estudis Universitaris Catalans, I5: 23I-49 
Roca, Josep M. 1923-24. 'Un cirurgià barber barcelonès de la XVª centúria', Boletín de la Real Academia de Buenas Letras de Barcelona, II.8I: I45-62 <https:/ / tinyurl.com/2yccbtyz $>$

Roca Pascual, Bernat. 2OII. 'Els Tous: ascens i caiguda d'un llinatge nobiliari català (segles XIII, XIV i XV)', Miscellanea Aqualatensia, I4: 4I-77 <https://tinyurl.com/u6h2dm4t $>$

Rubió i Balaguer, Jordi. r97I. Documentos para la historia de la Universidad de Barcelona, I: Preliminares (1289-1451) (Barcelona: Universitat de Barcelona)

Rubió i Lluch, Antoni. I9o8-2I. Documents per l'historia de la cultura catalana mig-eval, 2 vols (Barcelona: Institut d'Estudis Catalans) $\langle\underline{\text { https://go.uv.es/aBSK } 4 q 6>}$

Ruiz i Quesada, Francesc. 2003. 'Antoine de Lonhy', in La pintura gòtica hispanoflamenca: Bartolomé Bermejo i la seva època, ed. by Francesc Ruiz i Quesada (Barcelona: MNAC; Bilbao: Museo de Bellas Artes de Bilbao), pp. 328-33 $<$ https://tinyurl.com/dmdksxvr $>$

Salat, Josep. I8I8. Tratado de las monedas labradas en el Principado de Cataluña, con instrumentos justificativos, 2 vols (Barcelona: Impr. de Antonio Brusi) <https://tinyurl.com/9p65kr39>

Salleras Clarió, Joaquín. 2006. La baronía de Fraga: su progresiva vinculación a Aragón (1387-1458) (unpublished doctoral thesis, Universitat de Barcelona). $\langle$ http://hdl.handle.net/Io80z/2068 $>$

Sánchez Martínez, Manuel. 1993. 'Una aproximación a la estructura del dominio real en Cataluña a mediados del siglo XV: el Capbreu o memorial de les rendes e drets reyals de I44O-I444', in Estudios sobre renta, fiscalidad y finanzas en la Cataluña bajomedieval ed. by Manuel Sánchez Martínez, Anejos del Anuario de Estudios Medievales, 27 (Barcelona: CSIC, Institució Milà i Fontanals), pp. 38I-454

Santanach i Suñol, Joan. 20IO. 'Sobre la tradició catalana del Tristany de Leonís i un nou testimoni fragmentari', Mot So Razo, 9: 2I-38 $<\underline{\text { https://tinyurl.com/2ruzf } 4 \mathrm{r} 7}>$

Sciència.cat DB, coord. per Lluís Cifuentes i Comamala (Barcelona: Universitat de Barcelona, 2OI2-) $<\underline{\text { http://www.sciencia.cat/scienciacat-db }}>$ [consulta I-O3-2O2I]

Serra i Rotés, Rosa. 1982. Aproximació a la història de Puig-reig (Manresa: Gràf. Montañà)

Sobrequés i Callicó, Jaume. 1978. Catálogo de la Cancillería de Enrique IV de Castilla, señor del Principado de Cataluña (lugartenencia de Juan de Beaumont, 1462-1464), Anejos del Anuario de Estudios Medievales, 7 (Barcelona: CSIC, Institució Milà i Fontanals)

Soler i Palet, Josep. 1921. 'L'obra de Dante a Catalunya (notes)', Catalana, 4.92: I45-57

Soriano, Lourdes. 20I3. 'La literatura artúrica de la península Ibérica: entre membra disiecta, unica y códices repertoriales', $e$-Spania, I6 < https://tinyurl.com/ngpj5rxr $>$ [consulta 24-5-202I]

Tarragona i Muray, Jesús. I979. 'Inscripcions i làpides sepulcrals a la Seu Vella de Lleida', Ilerda, 40: $247-324$ https://tinyurl.com/yyzaz6fz $>$

Tavani, Giuseppe. 1980. 'Literatura i societat a Barcelona entre la fi del segle XIV i el començament del XV', in Actes del cinquè col.loqui internacional de llengua i literatura catalanes, Andorra 1979, ed. by Jordi Bruguera and Josep Massot i Muntaner (Barcelona: Publicacions de l’Abadia de Montserrat), 7-40 <https://tinyurl.com/2nzejngw $>$

Tomasin, Lorenzo. 20I9-20. 'Sul contatto linguistico nella Romania medievale: le lettere di Bartolo de Cavalli alias Bartol de Cavalls', Estudis Romànics, 41: 267-90, 42: 33-54 < https://tinyurl. com/zncntuz2 $>$ and $\langle\underline{\text { https: } / / \text { tinyurl.com/ybh5vhvy }>}$ 
Torras i Cortina, Miquel. 2004. L'escriptura i el llibre a la Catalunya Central als segles XIII $i$ $X I V$ (unpublished doctoral thesis, Universitat Autònoma de Barcelona) $<\underline{\text { http://hdl.handle. }}$ net/10803/5539>

Torró, Jaume. 20I4. 'La poesia cortesana', in Història de la literatura catalana, ed. by Àlex Broch (Barcelona: Enciclopèdia Catalana; Barcino; Ajuntament de Barcelona), vol. 2: Literatura medieval, II: Segles XIV-XV, ed. by Lola Badia, pp. 26I-352

Vela i Aulesa, Carles. 2003. L'obrador d'un apotecari medieval segons el llibre de comptes de Francesc ses Canes (Barcelona, 1378-1381), Anejos del Anuario de Estudios Medievales, 53 (Barcelona: CSIC, Institució Milà i Fontanals)

Vela i Aulesa, Carles. 2007a. Especiers i candelers a Barcelona a la Baixa Edat Mitjana: testaments, família i sociabilitat, 2 vols (Barcelona: Fundació Noguera; Lleida: Pagès)

Vela i Aulesa, Carles. 2007b. 'Les compravendes al detall i a crèdit en el món artesà: el cas dels especiers i els candelers', Barcelona Quaderns d'Història, I3: I3I-55 < https://tinyurl.com/ jnmnxmy? $>$

Wittlin, Curt J. r995. 'El manuscrit de la Catedral de Barcelona de la traducció catalana de les Històries troyanes', in Curt J. Wittlin, De la traducció literal a la creació literària: estudis filològics i literaris sobre textos antics catalans i valencians, Biblioteca Sanchis Guarner, 34 (València: Institut Interuniversitari de Filologia Valenciana; Barcelona: Publicacions de l'Abadia de Montserrat), pp. I8I-9I $<\underline{\text { https://tinyurl.com/yehzadbr }>}$ 